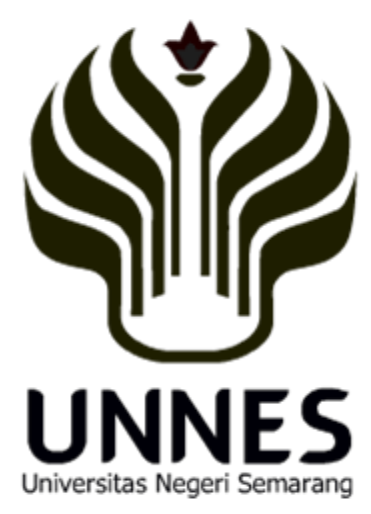

\title{
PEMBELAJARAN ANSAMBEL MUSIK DI SMPN 22 SEMARANG
}

\author{
Skripsi \\ disajikan sebagai salah satu syarat untuk memperoleh gelar Sarjana Pendidikan \\ Program Studi Pendidikan Seni Musik
}

\author{
Oleh \\ Yulfiani \\ 2501411069
}

JURUSAN PENDIDIKAN SENI DRAMA, TARI, DAN MUSIK

FAKULTAS BAHASA DAN SENI

UNIVERSITAS NEGERI SEMARANG

2017 


\section{LEMBAR PENGESAHAN}

Skripsi dengan judul Pembelajaran Ansambel Musik di SMPN 22 Semarang ini telah disetujui oleh panitia penguji dan disahkan oleh Dekan Fakultas Bahasa dan Seni pada tanggal 6 November 2017.

Drs. Syahrul Syah Sinaga, M . Hum. (196008031989011001)

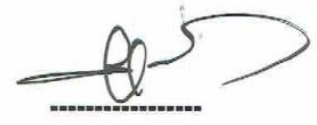

Ketua

Dra. Malarsih, M. Sn. (196106171988032001)

Sekretaris

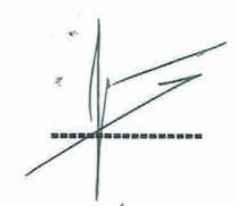

Dr. Udi Utomo, M . Si. (196708311993011001)

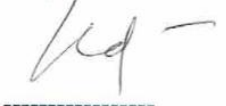

Penguji I

Abdul Rachman, S. Pd.,M.Pd (198001202006041002)

Penguji II

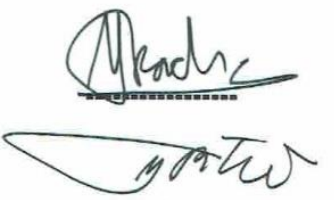

Drs. Suharto, S.Pd., M. Hum. (196510181990031002)

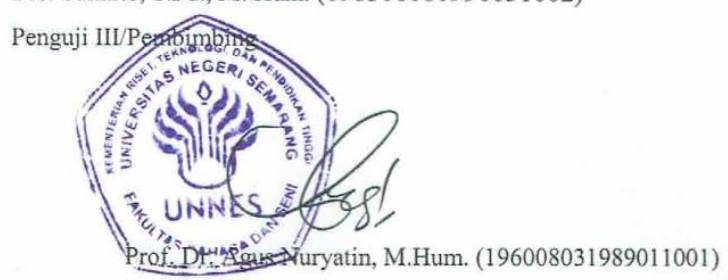

Dekan Fakultas Bahasa dan Seni 


\section{LEMBAR PERSETUJUAN BIMBINGAN}

Skripsi dengan judul "PEMBELAJARAN ANSAMBEL MUSIK DI KELAS VIII C SMPN 22 SEMARANG" telah disetujui oleh pembimbing untuk diajukan ke Sidang Panitia Ujian Skripsi Jurusan Pendidikan Seni Drama, Tari, dan Musik Fakultas Bahasa dan Seni Universitas Negeri Semarang pada tanggal 2 Oktober 2017.

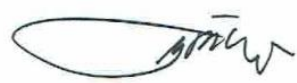

Drs. Suharto, S.Pd.,M.Hum (196510181990031002)

Pembimbing

Dr. Udi Utomo, M.Si (19670831199301101)

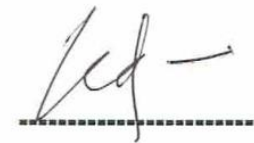

Ketua Jurusan 
PERNYATAAN

Yang bertanda tangan di bawah ini saya:

Nama $\quad$ : Yulfiani

NIM : 2501411069

Prodi Studi $\quad$ : Pendidikan Seni Musik

Jurusan $\quad$ : Pendidikan Sendratasik

Judul Skripsi : Pembelajaran Ansambel Musik Di Kelas VIII SMPN 22

Semarang

Menyatakan dengan sebenarnya bahwa skripsi yang saya serahkan ini benar-benar hasil karya saya sendiri kecuali kutipan dan ringkasan yang semua sumbernya tidak saya jelaskan. Apabila di kemudian hari terbukti atau dapat dibuktikan bahwa skripsi ini hasil jiplakan. maka pensusun bersedia menerima sangsi sesuai ketentuan yang berlaku.

\section{Semarang.}

6 November 2017

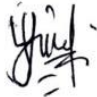

Yulfiani

NIM: 2501411069 


\section{MOTTO DAN PERSEMBAHAN}

\section{Motto:}

1. Sesungguhnya bersama kesulitan ada kemudahan. (QS Al Insyirah: 6)

2. Tidak ada kata gagal sebelum anda memutuskan untuk benar-benar berhenti mencoba.

\section{Persembahan:}

1. Mak dan Bapak saya

2. Dosen dan almameter saya 


\section{PRAKATA}

Segala Pujian saya panjatkan ke hadirat Allah Swt., yang telah memberikan ilmu dan karunia-Nya sehingga saya dapat menyelesaikan skripsi ini. Skripsi ini juga tidak mungkin bisa kami selesaikan tanpa bantuan dari pihak-pihak yang telah Allah atur dengan proporsi yang tepat. Oleh karena itu, pada kesempatan ini saya mengucapkan terima kasih kepada Drs. Suharto, S.Pd., M.Hum., dan Dra. Siti Aesijah. M.Pd yang telah membimbing proses penulisan skripsi ini. Saya juga mengucapkan kepada pihak-pihak berikut ini.

1. Dekan Fakultas Bahasa dan Seni Universitas Negeri Semarang yang dengan kebijakanya telah memudahkan pengurusan izin administrasi penelitian;

2. Ketua Jurusan Pendidikan Sendratasik Universitas Negeri Semarang yang telah memberikan fasilitas dan kebijakan perkuliahan;

3. Kepala SMPN 22 Semarang yang telah memebrikan izin penelitian;

4. Bapak Kasih. S.Pd. selaku guru mata pelajaran Seni Budaya kelas VIII SMPN 22 Semarang yang telah membantu proses penelitian;

5. Mak. Bapak dan Suami saya yang telah selalu mendoakan dan memberikan dukunganya dalam proses penulican skripsi ini;

6. Dan seluruh teman-teman yang secara langsung maupun tidak langsung turut mendukung proses penulisan skripsi ini.

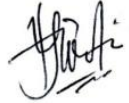

Yulfiani 


\section{SARI}

Yulfiani, 2017. "Pembelajaran Ansambel Musik di SMPN 22 Semarang." Skripsi Jurusan Pendidikan Seni Drama Tari dan Musik. Fakultas Bahasa dan Seni. Universitas Negeri Semarang. Pembimbing. Drs. Suharto, S.Pd.,M.Hum.

Kata kunci : pembelajaran, ansambel, musik

Seni musik sebagaimana bagian dari mata pelajaran seni budaya diajarkan di SMP baik pada kelas VII, VIII maupun IX. Pelajaran seni musik bisa diberikan dalam bentuk teori maupun praktik. Pada SMP yang menggunakan kurikulum tingkat satuan pendidikan (KTSP) terdapat kompetensi dasar menyajikan karya seni musik tradisional Nusantara secara perseorangan dan berkelompok di kelas atau di sekolah yang harus dicapai oleh siswa salah satunya yaitu di kelas VIII C. Untuk mencapai kompetensi dasar ini, di SMPN 22 Semarang pelaksanaan pembelajaranya cukup unik. Sebab, siswa diajarkan untuk dapat mengekspresikan diri dengan memainkan alat musik gamelan jawa. Seperti yang peneliti ketahui bahwa pada penelitian-penelitian yang telah dilakukan sebelumnya tentang ansambel kebanyakan dilaksanakan dengan menggunakan alat musik modern seperti pianika, recorder maupun gitar. Untuk itu, peneliti tertarik untuk mengetahui bagaimana proses pembelajaran ansambel musik gamelan jawa yang dilaksanakan di kelas VIII C SMPN 22 Semarang dan mengetahui bagaimana tanggapan siswa mengenai faktor-faktor yang mempengaruhi hasil belajar ansambel musik pada siswa kelas VIII C SMPN 22 Semarang.

Penelitian ini menggunakan jenis kualitatif deskriptif dengan analisis data menggunakan teknik kuantitatif dan kualitatif (mix methods). Teknik pengumpulan data menggunakan teknik wawancara, studi dokumen, observasi, dan teknik angket.

Hasil penelitian menunjukkan bahwa guru seni musik dalam melaksanakan pembelajaran ansambel musik menggunakan tiga tahapyaitu perencanaan, pelaksanaan, dan evaluasi. Pada tahap perencanaan guru mempersiapkan perangkat mengajar berupa silabus dan rencana pelaksanaan pembelajaran (RPP). Tahap pelaksanaan guru melaksanakan tiga kegiatan berupa kegiatan pendahuluan, kegiatan inti dan kegiatan akhir. Pada tahap evaluasi dilaksanakan dalam bentuk tes unjuk kerja. Adapun dalam pembelajaran ansambel musik gamelan jawa, faktor-faktor yang mempengaruhi proses dan hasil belajar ansambel musik gamelan jawa mendapat tanggapan positif dan negatif dari siswa. Tangggapan positif siswa diantaranya yaitu perhatian guru terhadap siswa, hubungan guru dengan siswa, bakat siswa, minat siswa, perhatian siswa, disiplin sekolah, media masa, bentuk kehidupan masyarakat, keadaan ekonomi keluarga, standar kurikulum, alat pelajaran, kesehatan siswa, cara orang tua mendidik, dan pengertian orang tua. Sedangkan faktor-faktor yang mendapat tanggapan negatif dari siswa yaitu perhatian guru dalam memberikan tugas, keadaan gedung, motif siswa, dan standar pelajaran di atas ukuran.

Harapanya pembelajaran seni musik lebih direncanakan lagi secara matang agar pelaksanaannya bisa berjalan sesuai dengan perencanaan yang telah dibuat. 


\section{DAFTAR ISI}

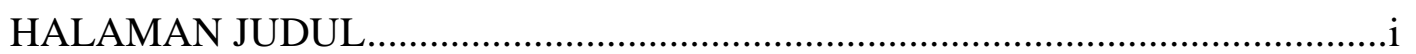

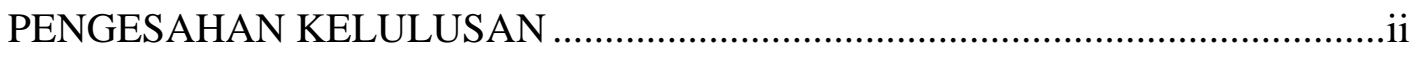

PERSETUJUAN BIMBINGAN ......................................................................

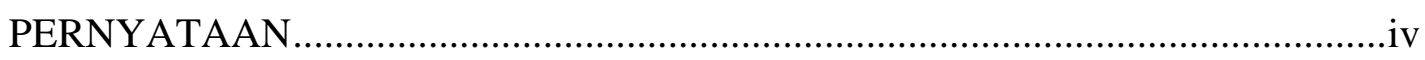

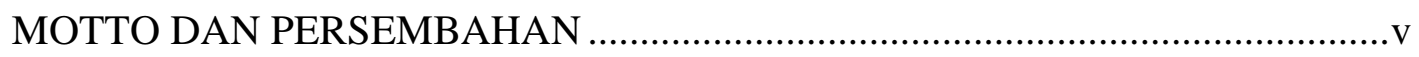

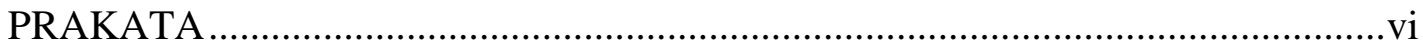

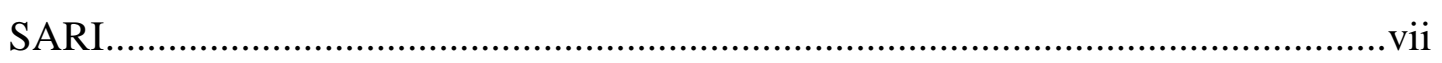

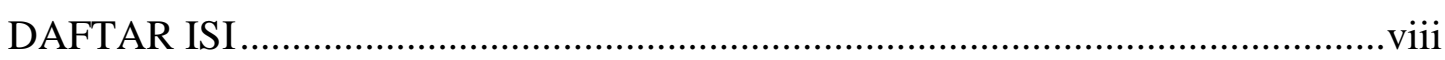

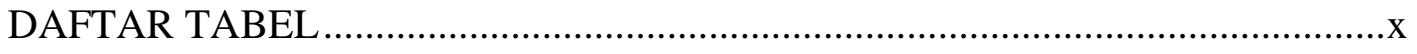

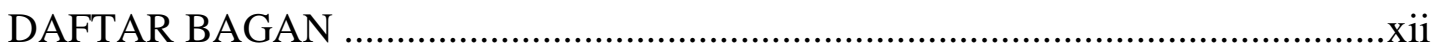

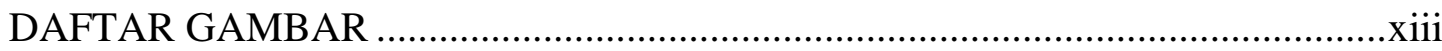

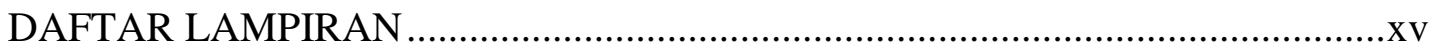

\section{BAB I PENDAHULUAN}

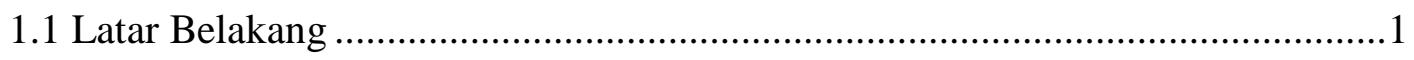

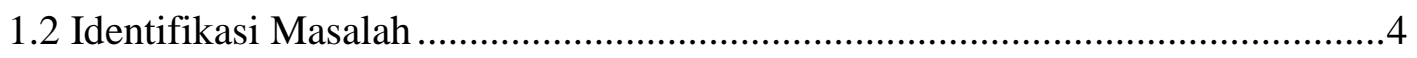

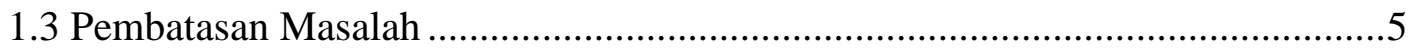

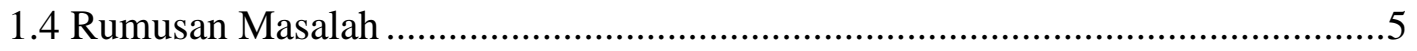

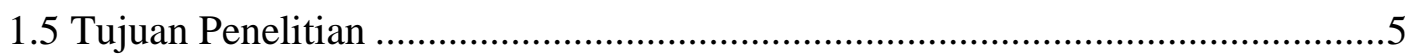

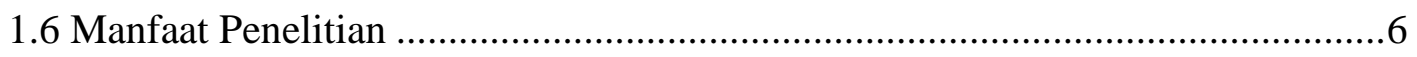

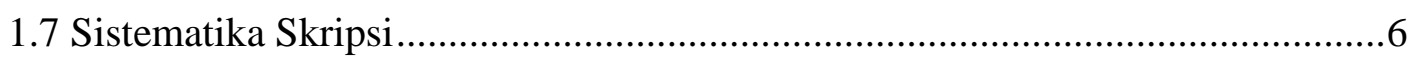

\section{BAB II KAJIAN PUSTAKA}

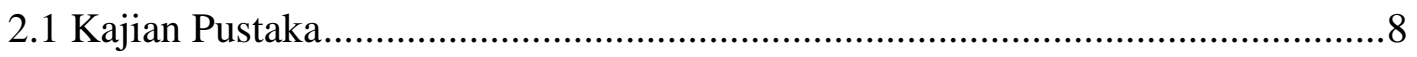

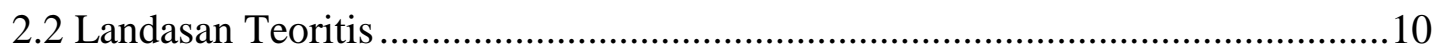

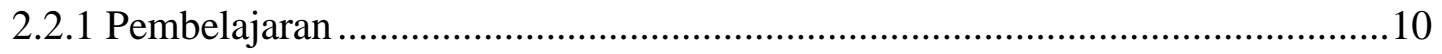

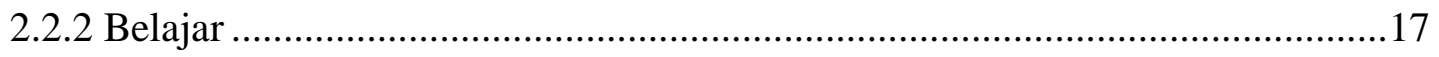

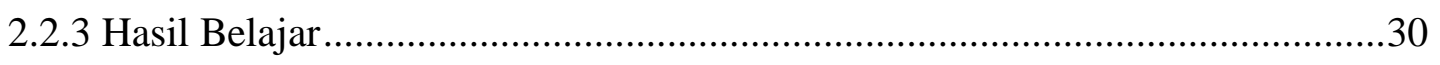

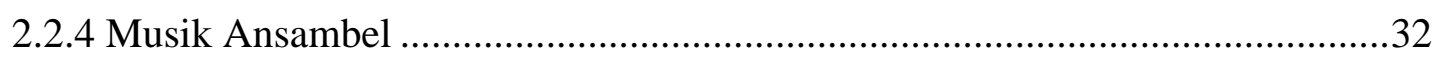

BAB III METODE PENELITIAN

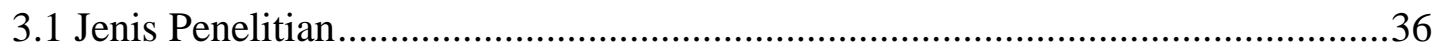




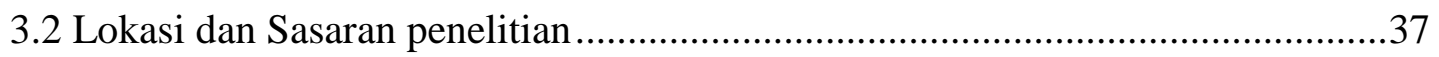

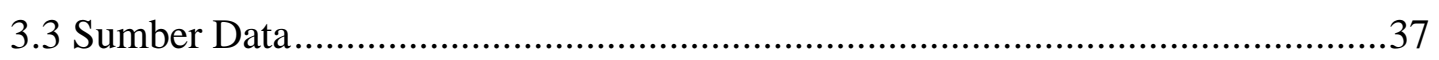

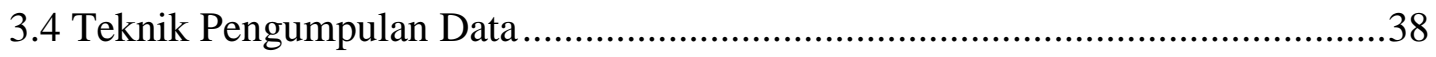

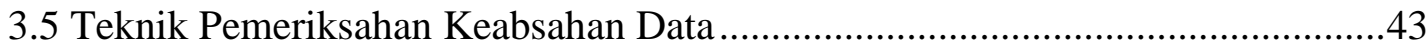

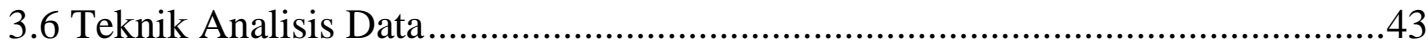

\section{BAB IV HASIL PENELITIAN}

4.1 Gambaran Umum Lokasi Penelitian ............................................................48

4.2 Implementasi Pembelajaran Ansambel Musik di SMPN 22 Semarang ..............59

4.2.1 Pembelajaran Karawitan sebagai Alternatif dalam Melaksanakan Kompetensi Menampilkan Lagu Etnik Nusantara dalam Bentuk Ansambel Musik

4.2.2 Kegiatan Perencanaan, Pelaksanaan, dan Evaluasi pembelajaran Ansambel

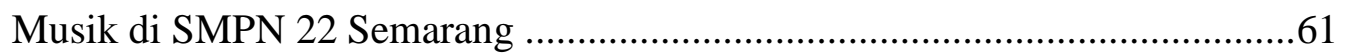

4.3 Faktor yang Mempengaruhi Hasil Belajar Ansambel Musik..............................70

BAB V PENUTUP

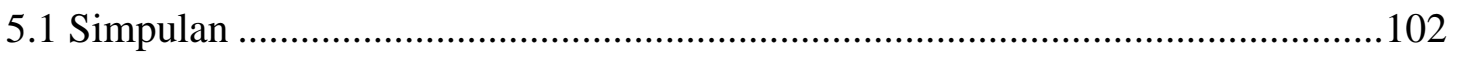

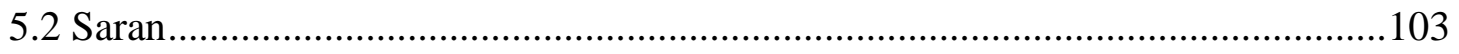

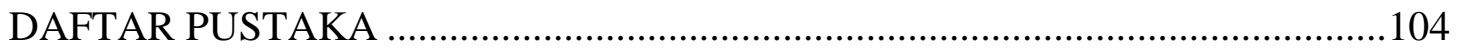

LAMPIRAN-LAMPIRAN 


\section{DAFTAR TABEL}

Tabel 3.1 Kisi-kisi Angket Faktor-faktor yang Memengaruhi Hasil Belajar

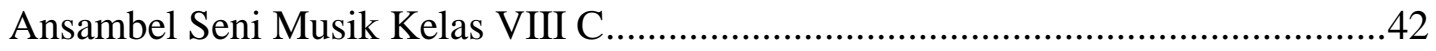

Tabel 3.2 Kualifikasi Hasil Presentase Skor Tiap Butir Pertanyaan.........................47

Tabel 4.1 Kualifikasi Pendidikan, Status, Jenis Kelamin, dan Jumlah Guru..............54

Tabel 4.2 Data Kepala Sekolah dan Wakil Kepala sekolah....................................55

Tabel 4.3 Jumlah Guru Sesuai dengan Latar Belakang Pendidikan .........................55

Tabel 4.4 Jumlah Siswa SMPN 22 Semarang ..................................................57

Tabel 4.5 Tenaga Administrasi dan Tenaga Pendukung SMPN 22 Semarang..........58

Tabel 4.6 Perhatian Guru Kepada Siswa................................................................ 71

Tabel 4.7 Perhatian Guru dalam Memberikan Tugas Kepada Siswa.........................72

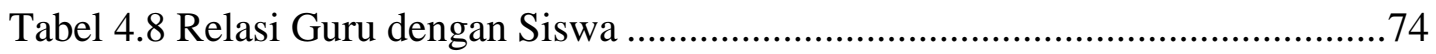

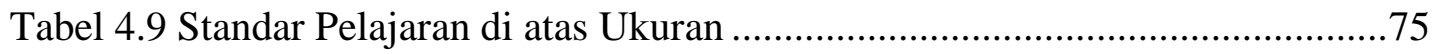

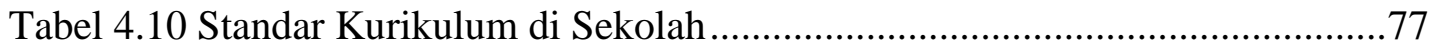

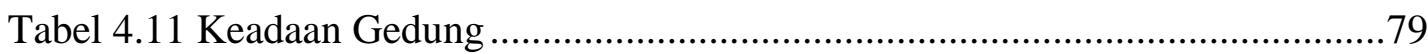

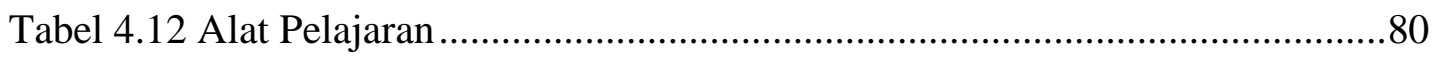

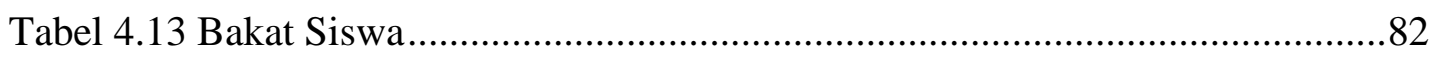

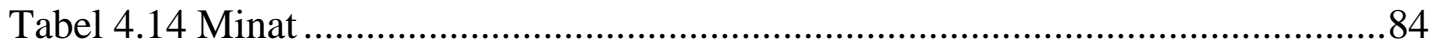

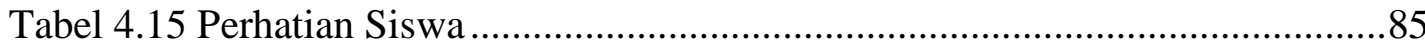

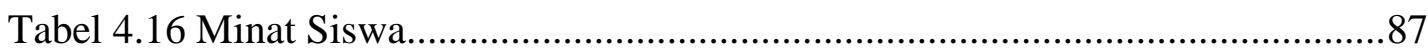

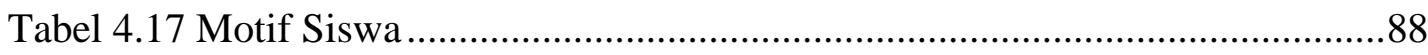

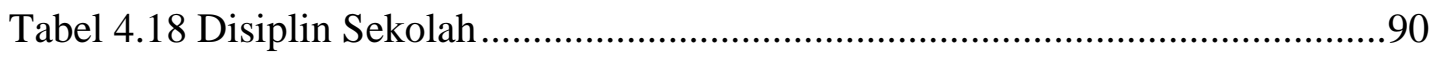

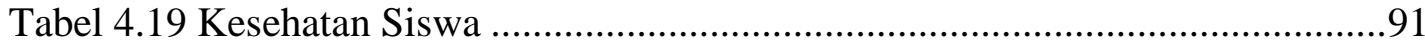




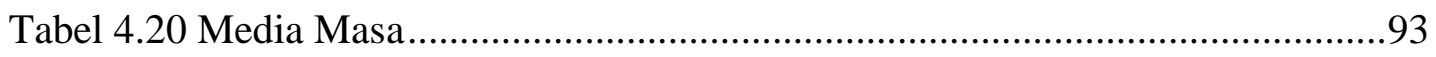

Tabel 4.21 Bentuk Kehidupan Masyarakat ..........................................................94

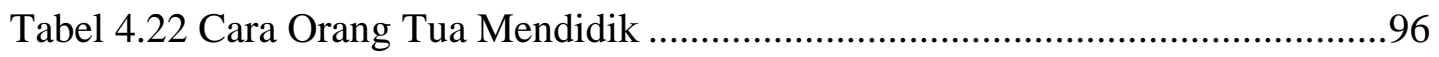

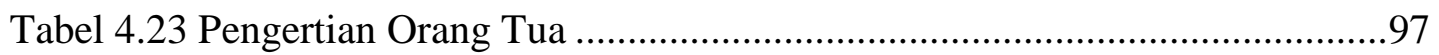

Tabel 4.24 Keadaan Ekonomi Keluarga ..............................................................99 


\section{DAFTAR BAGAN}

Bagan 3.1 Komponen-komponen Analisi Data : Model Interaktif ...........................44

Bagan 4.1 Struktur Organisasi SMPN 22 Semarang .............................................56 


\section{DAFTAR GAMBAR}

Gambar 4.1 Pintu Gerbang SMPN 22 Semarang..................................................48

Gambar 4.2 Histogram Perhatian Guru terhadap Siswa ........................................ 72

Gambar 4.3 Histogram Perhatian Guru dalam Memberikan Tugas kepada Siswa....73

Gambar 4.4 Histogram Relasi Guru dengan Siswa............................................... 75

Gambar 4.5 Histogram Standar Pelajaran di atas Ukuran...................................... 77

Gambar 4.6 Histogram Standar Kurikulum bagi Siswa........................................ 78

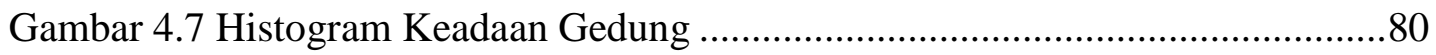

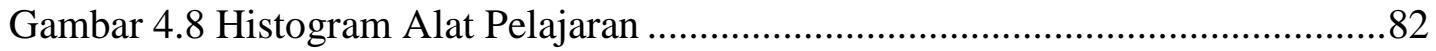

Gambar 4.9 Histogram Bakat....................................................................... 83

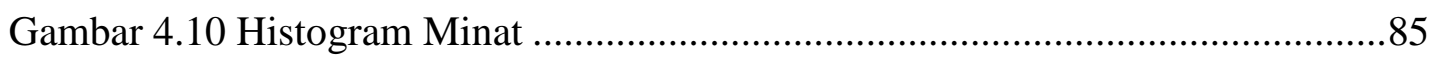

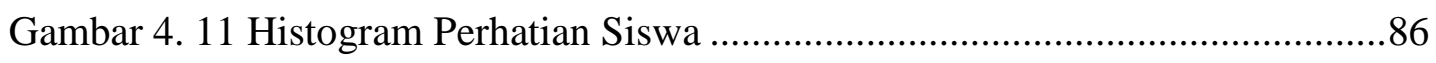

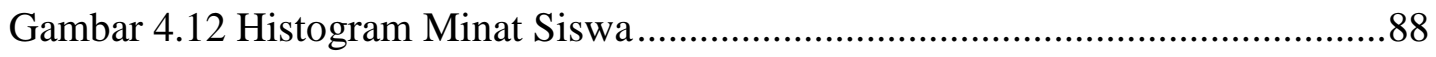

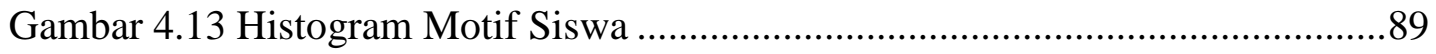

Gambar 4.14 Histogram Disiplin Sekolah .......................................................91

Gambar 4.15 Histogram Kesehatan Siswa.......................................................92

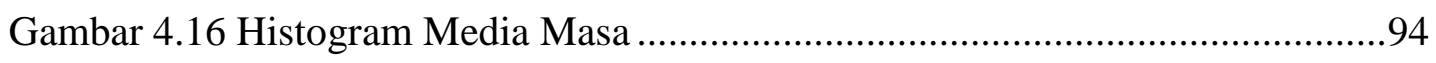

Gambar 4.17 Histogram Bentuk Kehidupan Masyarakat ........................................95

Gambar 4.18 Histogram Cara Orang Tua Mendidik...............................................97

Gambar 4.19 Histogram Pengertian Orang Tua....................................................98

Gambar 4.20 Histogram Keadaan Ekonomi Keluarga............................................100

Gambar 5.21 Notasi Gamelan Jawa ditulis di Papan Tulis Ruang Gamelan Jawa................116

Gambar 5.22 Siswa Saat Mengikuti Proses Pembelajaran Ansambel Gamelan 
Jawa

Gambar 5.23 Pergantian Kelompok Saat Latihan

Gambar 5.24 Siswa Berlatih dengan Melihat Notasi di Papan Tulis Depan Kelas ...117

Gambar 5.25 Siswa Sedang Berlatih Memainkan Kethuk 118

Gambar 5.26 Siswa Sedang Berlatih Memainkan Kenong 118

Gambar 5.27 Siswa Sedang Memainkan Gong 119

Gambar 5.28 Siswa Sedang Memainkan Bonang Penerus 119

Gambar 5.29 Siswa Sedang Memainkan Bonang Barung 120

Gambar 5.30 Siswa Sedang Memainkan Seluruh Alat Musik Gamelan Jawa

Secara Berkelompok 120

Gambar 5.31 Alat Musik Drum di Ruang Musik 121

Gambar 5.32 Alat Musik Rebana di Ruang Musik 121

Gambar 5.33 Gitar Klasik di Ruang Musik 122

Gambar 5.34 Keyboard di Ruang Musik 122

Gambar 5.35 Gitar di Ruang Musik 123

Gambar 5.36 Pianika dan Recorder di Ruang Musik 123

Gambar 5.37 Ruang Kelas 124 


\section{DAFTAR LAMPIRAN}

Lampiran 1 Rencana Pelaksanaan Pembelajaran (RPP) ........................................107

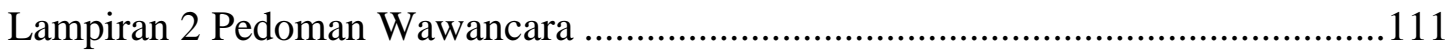

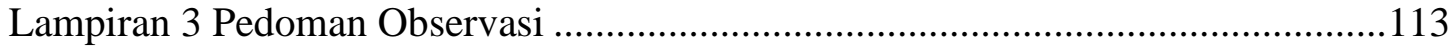

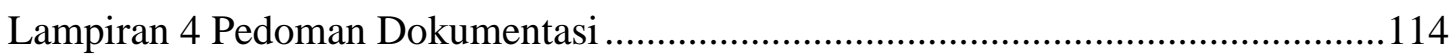

Lampiran 5 Notasi Lagu Suwe Ora Jamu .......................................................... 115

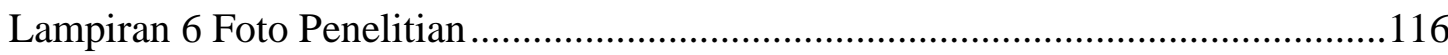

Lampiran 7 Contoh Hasil Pengisisan Angket Siswa Kelas VIII................................125

Lampiran 8 Surat Bukti Telah Melakukan Penelitian..............................................129

Lampiran 9 Surat Tugas Panitia Ujian Sarjana ........................................................ 130

Lampiran 10 Surat Keputusan Bimbingan Skripsi...............................................131 


\section{BAB I}

\section{PENDAHULUAN}

\subsection{Latar Belakang Masalah}

Tujuan dari pendidikan sebagaimana tercantum di dalam UU No. 20 tahun 2003 tentang Sikdiknas berbunyi pendidikan adalah usaha sadar dan terencana untuk mewujudkan suasana belajar dan proses pembelajaran agar peserta didik secara aktif mengembangkan potensi dirinya untuk memiliki kekuatan spiritual keagamaan, pengendalian diri, kepribadian, kecerdasan, akhlak mulia, serta keterampilan yang diperlukan dirinya, masyarakat dan bangsa.

Dalam rangka mencapai tujuan pendidikan nasional, pendidikan seni budaya sangat berkontribusi dalam pembentukan manusia Indonesia seutuhnya. Sebab, pendidikan seni budaya dan keterampilan memiliki peranan dalam pembentukan pribadi peserta didik yang harmonis dengan mempertimbangkan kebutuhan perkembangan anak dalam mencapai multi kecerdasan yang terdiri atas kecerdasan intrapersonal, visual spasial, musikal, linguistik, logik matematik, naturalis, kecerdasan adversitas, kecerdasan kreativitas, kecerdasan spiritual dan moral, dan kecerdasan emosional (Utomo dan Sinaga, 2009).

Seni musik yang di dalam kurikulum tingkat satuan pendidikan termasuk pada bagian dari mata pelajaran seni budaya merupakan salah satu mata pelajaran yang ada di pendidikan formal/sekolah mempunyai tujuan khusus yang berbeda dari mata pelajaran lainya. Tujuan khusus seni budaya antara lain menumbuhkembangkan sikap toleransi, menciptakan demokrasi yang beradab, menumbuhkan hidup rukun dalam masyarakat majemuk, mengembangkan 
kepekaan rasa dan keterampilan, menerapkan teknologi dalam berkreasi, menumbuhkan rasa cinta budaya dan menghargai warisan budaya Indonesia, serta membuat pergelaran dan pameran karya seni (Kemendikbud, 2014:2). Berdasarkan tujuan khusus tersebut, menumbuhkan rasa cinta budaya dan menghargai warisan budaya Indonesia merupakan hal yang sangat penting untuk dilakukan.

Sebagaimana yang kita ketahui bahwa Indonesia yang wilayahnya mulai dari sabang sampai merauke mempunyai warisan budaya secara turun temurun dan harus tetap dijaga dan dilestarikan keberadaanya agar tidak punah dan diakui oleh negara lain. Salah satu kesenian tradisional warisan budaya jawa yang sudah dikenal dan dipelajari diberbagai negara di dunia yaitu gamelan jawa.

Gamelan jawa yang menjadi identitas yang dihidupi oleh orang jawa selama bertahun-tahun saat ini mengalami erosi akibat kuatnya pengaruh barat yang disebarkan melalui teknologi media seperti film dan televisi. Anak-anak muda jaman sekarang lebih menyukai tari, lagu, dan musik barat ketimbang seni tradisional. Mereka lebih memilih mempelajari seni musik barat dari pada belajar karya seni tradisi. Karya seni barat terkesan lebih modern dan lebih bergengsi, juga lebih ekspresif, spontan dan energik sehingga dirasa lebih pas dengan gejolak jiwa muda (Eman, 2015).

Padahal sesungguhnya budaya lokal yang kita miliki ini dapat menjadikan kita lebih bernilai dibandingkan bangsa lain. Karena betapa berharganya nilainilai budaya lokal yang ada di negara ini. Untuk itu seharusnya kita lebih tanggap 
dan peduli lagi terhadap semua kebudayaan yang ada di Indonesia ini, agar budaya kita tetap terjaga dan tidak diambil orang lain (Satria, 2015).

Salah satu cara untuk meningkatkan ketahanan budaya bangsa adalah mengadakan pembelajaran seni musik gamelan jawa melalui lembaga pendidikan formal atau sekolah, dengan memasukkan seni musik gamelan jawa sebagai bahan atau materi pelajaran. Dengan mempelajari gamelan jawa di sekolah maka siswa akan melalui berbagai proses yang akan membentuk dasar pengetahuan yang tersusun dengan baik dan pemahaman yang baik pula terhadap gamelan jawa. Dari kegiatan mempelajari gamelan jawa maka harapanya akan timbul rasa menghargai, memiliki, dan pada akhirnya akan mencintai budaya bangsa ini pada diri siswa.

Di sekolah menengah pertama yang menerapkan kurikulum tingkat satuan pendidikan (KTSP), masih banyak guru seni musik yang belum berani menggunakan ansambel gamelan jawa sebagai materi pelajaran seni musik kelas VIII. Mereka lebih memilih mengajar dengan alat modern seperti pianika, recorder, dan gitar meskipun lagu yang dimainkan adalah lagu tradisional. Salah satu sekolah yang menggunakan musik gamelan jawa dalam kegiatan pembelajaran melalui mata pelajaran seni budaya dengan alokasi waktu dua jam pelajaran setiap pertemuan pembelajaran yaitu SMPN 22 Semarang. Di sekolah tersebut yang diajarkan gamelan jawa adalah siswa kelas VIII termasuk salah satunya yaitu kelas VIII C. Melalui kelas tersebutlah penulis akan melakukan penelitian untuk mengetahui bagaimana proses pembelajaran ansambel gamelan jawa yang dilaksanakan di SMPN 22 Semarang. 
Dalam setiap proses pembelajaran, keoptimalan dalam pembelajaran adalah harapan dari setiap orang termasuk guru, orang tua, maupun masyarakat. Namun, untuk mencapai keoptimalan tersebut ada banyak faktor yang mempengaruhi baik mempengaruhi keberhasilan belajar siswa maupun menghambat keberhasilan siswa. Faktor-faktor tersebut dapat berasal dari lingkungan keluarga, sekolah, maupun lingkungan masyarakat. Menurut Daryanto (2013:36) faktor-faktor yang mempengaruhi keberhasilan belajar siswa terdiri atas faktor intern dan faktor ekstern. Faktor intern berasal dari diri siswa sendiri dan faktor ekstern berasal dari luar diri siswa. Begitu juga di dalam pembelajaran ansambel gamelan jawa ada banyak faktor yang mempengaruhi keberhasilan siswa dalam belajar. Di sini penulis ingin mengetaui bagaimana tanggapan siswa mengenai faktor-faktor apa saja yang mempengaruhi keberhasilan belajar ansambel gamelan jawa. Dengan mengetahui tanggapan siswa harapanya proses pembelajaran ansambel gamelan jawa ke depanya menjadi lebih baik dan lebih optimal.

\subsection{Identifikasi Masalah}

Bermain musik dibagi menjadi dua kategori, yaitu bermain musik secara individu dan kelompok. Sesuai dengan kompetensi dasar yang akan diteliti dalam penelitian ini maka keterampilan yang akan diteliti adalah keterampilan bermain musik secara berkelompok atau ansambel.

Tugas guru dalam pembelajaran meliputi tiga hal. Pertama, membuat perencanaan, kedua melaksanakan pembelajaran, dan ketiga melakukan penilaian. Ketiga hal tersebut termasuk ke dalam bagian yang akan dibahas oleh peneliti 
yaitu tentang bagaimana pembelajaran ansambel di kelas VIII C SMPN 22 Semarang. Adapun penilaian disebut juga sebagai hasil belajar. Berdasarkan latar belakang yang telah ditulis, fokus penelitian ini yaitu hasil belajar siswa dalam bermain musik secara berkelompok atau ansambel.

Di dalam pembelajaran ada beberapa faktor yang mempengaruhi. Adapun dalam penelitian ini yang akan dikaji adalah faktor intern dan ekstern yang memengaruhi hasil belajar ansambel musik pada siswa kelas VIII C SMP/MTs.

\subsection{Pembatasan Masalah}

Batasan yang diambil dalam penelitian ini adalah tanggapan siswa mengenai faktor-faktor yang mempengaruhi hasil belajar bermain musik ansambel siswa kelas VIII C SMP/MTS dan bagaimana proses terlaksananya pembelajaran musik ansambel di kelas VIII C SMPN 22 Semarang.

\subsection{Rumusan Masalah}

1.4.1 Bagaimanakah implementasi pembelajaran ansambel musik di kelas VIII C SMPN 22 Semarang?

1.4.2 Bagaimanakah tanggapan siswa terhadap faktor-faktor yang mempengaruhi hasil belajar ansambel musik pada kelas VIII C SMPN 22 Semarang ?

\subsection{Tujuan Penelitian}

1.5.1 Untuk mengetahui bagaimana implementasi pembelajaran ansambel musik di kelas VIII C SMPN 22 Semarang. 
1.5.2 Untuk mengetahui tanggapan siswa terhadap faktor-faktor yang mempengaruhi hasil belajar ansambel musik pada siswa kelas VIII C SMPN 22 Semarang.

\subsection{Manfaat Penelitian}

1.6.1 Manfaat secara teoritis

Penelitian diharapkan dapat menambah khasanah baru dalam dunia pendidikan khususnya dalam pembelajaran Ansambel Seni Musik.

\subsubsection{Manfaat secara praktis}

Manfaat secara praktis di dapatkan setelah penelitian dilakukan, yakni membantu menemukan permasalahan pembelajaran. Penelitian ini memiliki manfaat bagi siswa dan guru seni musik.

1.6.2.1 Bagi guru. Pertama, sebagai refleksi dalam memperbaiki kualitas pembelajaran. Kedua, mampu memberi arah dan bimbingan kepada siswa dalam mencapai tujuan pembelajaran dengan tepat.

1.6.2.2 Bagi siswa. Dengan mengetahui faktor-faktor yang memengaruhi hasil belajar, akan lebih mengoptimalkan proses pembelajaran yang berpusat kepada siswa.

\subsection{Sistematika Skripsi}

Untuk mengetahui garis besar isi penelitian ini maka terlebih dahulu penulis akan menguraikan secara singkat sebagai berikut : 


\subsubsection{Bagian Awal}

Bagian ini berisi halaman judul, pengesahan, persetujuan bimbingan, motto dan persembahan, kata pengantar, sari, daftar isi, daftar singkatan, daftar tabel, daftar bagan, daftar diagram, daftar gambar, dan daftar lampiran.

\subsubsection{Bagian Isi}

Bagian ini terbagi menjadi lima bab yaitu :

Bab 1: Pendahuluan, berisi: latar belakang masalah, identifikasi masalah, pembatasan masalah, rumusan masalah, tujuan penelitian, manfaat penelitian, dan sistematika skripsi.

Bab 2: Kajian Pustaka dan Landasan Teori, berisi: kajian pustaka dan landasan teoritis. Landasan teori berisi: pembelajaran, belajar dan hasil belajar, musik ansambel.

Bab 3: Metode Penelitian, berisi: jenis penelitian, lokasi penelitian, sumber data, teknik pengumpulan data, teknik pemeriksaan keabsahan data, teknik analisis data.

Bab 4: Hasil Penelitian dan Pembahasan, berisi: gambaran umum lokasi penelitian, hasil penelitian, pembahasan.

Bab 5: Penutup, berisi: simpulan dan saran dari penelitiian.

\subsubsection{Bagian Akhir}

Bagian ini terdapat daftar pustaka yang berkaitan dengan penelitian dan lampiran-lampiran yang memuat kelengkapan penelitian. 


\section{BAB II}

\section{KAJIAN PUSTAKA DAN LANDASAN TEORITIS}

\subsection{Kajian Pustaka}

Penelitian mengenai pembelajaran ansambel sudah pernah dilakukan oleh peneliti sebelumnya. Penelitian-penelitian yang relevan untuk dijadikan tinjuan pustaka yaitu : Sunardi (2013), Febrianto (2011), dan Abdul Rachman (2016).

Penelitian yang dilakukan Sunardi (2013) berjudul "Meningkatkan Hasil Belajar Musik Ansambel Melalui Metode Tutor Sebaya kelas VIID SMP Negeri 14 Purworejo Tahun Pelajaran 2013/2013. Penelitian ini bertujuan untuk mengetahui, mendiskripsikan, dan menganalisa peningkatan hasil belajar bermian rekorder pada pembelajaran ansambel di kelas VIID SMP Negeri 12 Purworejo melalui melalui metode tutor sebaya, dan mengetahui serta mendiskripsikan peningkatan hasil belajar bermain pianika pada pembelajaran ansambel di kelas VIID SMP Negeri 12 Purworejo melalui metode tutor sebaya. Penelitian ini menggunakan pendekatan Penelitian Tindakan Kelas dengan menggunakan metode kualitatif dan kuantitatif.

Hasil penelitian menunjukkan bahwa metode tutor sebaya mampu meningkatkan hasil belajar musik ansambel dan mampu mengefektifkan waktu pertemuan di dalam kelas dibandingkan dengan metode klasikal. Persamaanya adalah penelitian Sunardi berorientasi pada peningkatan hasil belajar sedangkan penelitian ini berorientasi pada pembelajaran ansambel musik. Sedangkan perbedaan penelitian tersebut dengan penelitian ini yaitu pada pendekatan penelitianya. 
Penelitian yang dilakukan oleh Febrianto (2011) berjudul "Pembelajaran Ansambel Musik di Kelas VIII pada SMP Negeri 1 Pangkah Tegal”. Tujuan penelitian ini adalah untuk mengetahui dan mendiskripsikan pembelajaran ansambel musik di kelas VIII pada SMP Negeri 1 Pangkah. Penelitian ini menggunakan pendekatan deskriptif dan merupakan jenis penelitian kualitatif. Hasil penelitian menunjukkan bahwa pembelajaran ansambel musik di SMP N 1 Pangkah dibagi empat tahap yaitu tahap persiapan, tahap pelaksanaan, tahap evaluasi, dan remidi/tindak lanjut. Penelitian tersebut dengan penelitian ini memiliki persamaan pada pendekatan penelitianya.

Penelitian yang dilakukan oleh Abdul Rachman (2016) berjudul "Penggunaan Media Backing Track Pada Materi Memainkan Pola Iringan Keroncong di Jurusan Sendratasik Universitas Negeri Semarang”. Penelitian ini bertujuan untuk mengetahui faktor pendukung penggunaan media backing track pada pembelajaran mata kuliah keroncong di jurusan sendratasik program studi pendidikan seni musik universitas negeri semarang dan mengetahui bagaimana penggunaan media backing track pada mata kuliah keroncong di jurusan sendratasik program studi pendidikan seni musik universitas negeri semarang. Penelitian ini menggunakan pendekatan penelitian kualitatif dengan menggunakan metode deskriptif analisis dan interpretatif dengan memanfaatkan data kualitatif.

Hasil penelitian menunjukkan bahwa faktor pendukung dalam pembuatan backing track iringan musik keroncong adalah perangkat keras dan perangkat lunak. Perangkat keras tersebut adalah komputer, soundcard, speaker flat, headphone, mic, bass, cello petik, cak dan cuk. Sedangkan perangkat lunak 
(software) adalah software neudo. Sedangkan penggunaan media backing track pada pembelajaran mata kuliah keroncong adalah dengan memutar audio backing track iringan keroncong pola iringan engkel dan double, memutar backing track iringan keroncong lagu langgam "Unnes Konservasi” pada materi mengiringi lagu langgam keroncong, memutar audio backing track lagu "Keroncong Bebas" pada materi mengiringi lagu keroncong asli, dan memutar audio backing track lagu "Berawal dari Tatap" pada materi mengiringi lagu keroncong bebas. Ketika audio backing track diputar para mahasiswa memainkan alat musik bass, cello, cuk, dan cak sesuai dengan iringan audio backing track yang diputar.

Persamaan penelitian ini terletak pada penggunaan pendekatanya yaitu pendekatan kualitatif. Sedangkan perbedaanya teknik analisis datanya. Penelitian tersebut menggunakan teknik analisis data kualitatif, sedangkan penelitian ini menggunakan teknik analisis mix methods.

\subsection{Landasan Teoritis}

Beberapa teori yang akan dibahas dalam landasan teoritis ini yaitu tentang teori pembelajaran, belajar, hasil belajar, dan ansambel.

\subsubsection{Pembelajaran}

\subsubsection{Pengertian Pembelajaran}

Istilah pembelajaran lahir oleh sebab adanya interaksi antara guru dan siswa dalam ranah pendidikan. Pembelajaran merupakan padanan dalam bahasa Inggris instruction yang berarti proses membuat orang belajar (Husamah dalam Fitriyati, 2016:17). Pembelajaran merupakan aktivitas paling utama dalam proses pendidikan di sekolah. Pembelajaran merupakan suatu proses yang dilakukan 
individu untuk memperoleh perubahan perilaku yang baru secara keseluruhan, sebagai hasil pengalaman individu itu sendiri dalam interaksi dengan lingkunganya (Yudhawati dan Haryanto, 2011:14). Adapun proses pembelajaran merupakan sebuah aktivitas yang terpenting bagi manusia, alasanya: (1) individu akan merasakan adanya kebutuhan dan melihat tujuan yang ingin ia capai; (2) kesiapan (readiness) individu untuk mengetahui kebutuhan dan mencapai tujuan; (3) pemahaman situasi lingkungan; (4) menafsirkan situasi yaitu bagaimana individu melihat kaitan berbagai aspk yang terdapat dalam situasi; (5) tindakan balasan (respons); (6) akibat (hasil) pembelajaran (Yudhawati dan Haryanto, 2011:15).

Hasil dari proses pembelajaran adalah perubahan perilaku individu. Individu akan memeproleh perilaku yang baru, menetap, fungsional, positif, disadari dan sebagainya. Perubahan perilaku sebagai hasil pembelajaran ialah perilaku keseluruhan yang mencangkup aspek kognitif, afektif, dan psikomotorik (Yudhawati dan Haryanto, 2011:16). Jenis-jenis pembelajaran berdasarkan aspek pembelajaran yang akan dicapai yaitu: pembelajaran keterampilan, pembelajran sikap dan pembelajaran pengetahuan. Dan sifatnya dibedakan antara pembelajaran formal, informal, dan non formal (Yudhawati dan Haryanto, 2011:16). Sebuah pembelajaran dirancang dengan tujuan untuk menghasilkan proses belajar. Upaya ini dilakukan oleh guru dengan pertimbangan yang matang dan tersruktur. Sebuah pembelajaran harus menghasilkan belajar pada siswa dan harus dilakukan suatu perencanaan yang sistematis (Siregar 2014: 14). 
Sebuah pembelajaran memiliki sifat yang sangat kompleks karena melibatkan aspek pedagogis, psikologis, dan didaktis (Mulyasa dalam Fitriyati, 2016:18). Pedagogis bermakna bahwa guru menjadi pendamping siswa dalam proses belajar di lingkungan pendidikan yang terprogram. Psikologis bermakna bahwa siswa memiliki kemampuan belajar dan sifat serta kepribadian yang bermacam-macam sehingga guru pun harus memahami siswanya tidak sebatas luarnya saja. Sedangkan didaktis bermakna bahwa seorang guru harus memilih dan menentukan jenis pembelajaran yang akan diterapkan dengan menyesuikan dengan kompetensi yang akan diajarkan (Fitriyati, 2016:18).

Dari pendapat di atas dapat disimpulkan bahwa pembelajaran diartikan sebagai usaha pendidikan yang dilaksanakan secara terencana baik waktu, materi, proses, maupun hasil yang diharapkan dengan seperangkat tindakan yang dirancang untuk mendukung proses belajar siswa dimana tujuan pembelajaran telah ditetapkan sebelum proses belajar dilaksanakan.

\subsubsection{Komponen Pembelajaran}

Proses pembelajaran terjadi atas komponen-komponen yang ada di dalamnya. Komponen tersebut terdiri dari tujuan pembelajaran, materi pengajaran, pendidik, siswa, metode, evaluasi, dan alat/ sarana dan prasarana (Djamrah dalam Khamim, 2011:11).

a. Tujuan pembelajaran, tujuan pembelajaran yaitu tujuan yang hendak dicapai setelah terselenggaranya proses belajar mengajar. Tujuan pembelajaran merupakan hal utama yang harus difikirkan sebelum proses belajar mengajar dilaksanakan. Tujuan pembelajaran merupakan arah yang akan dituju dalam 
melaksanakan proses pembelajaran. Menurut Djamrah dalam Khamim (2011:11-12) di dalam tujuan pembelajaran terdapat sejumlah nilai yang harus ditanamkan kepada anak didik. Nilai-nilai itu nantinya akan mewarnai cara anak didik bersikap dan berbuat dalam lingkungan sosialnya baik di sekolah maupun di luar sekolah.

b. Materi pengajaran, materi pelajaran adalah bagian dari struktur keilmuan suatu bahan kajian yang dapat berupa pengertian konseptual, gugus isi atau konteks, proses, bidang ajar, dan keterampilan. Pokok bahasan memuat materi pembelajaran yang merupakan bahan untuk mencapai KD yang ditargetkan. Bahan pembelajaran ini harus benar-benar dapat menghantarkan tercapainya KD yang ditentukan. Harjanto (2003) Mengidentifikasi materi pokok/pembelajaran yang menunjang pencapaian kompetensi dasar dengan memperrtimbangkan: (a) potensi peserta didik; (b) relevansi dengan karakteristik daerah; (c) tingkat perkembangan fisik, intelektual, emosional, sosial, dan spiritual peserta didik; (d) kebermanfaatan bagi peserta didik; (e) struktur keilmuan; (f) aktualisasi, kedalaman, dan keluasan materi pembelajaran; (g) relevansi dengan kebutuhan peserta didik dan tuntutna lingkungan; (h) alokasi waktu (dalam Wahab, 2015:209).

c. Metode, metode merupakan cara yang digunakan guru dalam menyampaikan pelajaran yang disesuaikan dengan pokok bahasan yang diajarkan. Sehubungan dengan hal tersebut Willis (2012:99) mengatakan metode mengajar merupakan cara-cara tertentu yang dilakukan guru, untuk menyampaikan materi pelajaran, sehingga dapat dipahami dan dikuasai oleh 
anak didik, hingga dapat mengubah perilaku anak didik ke arah yang lebih baik sesuai dengan tujuan pendidikan. Ada beberapa macam metode yang sering digunakan guru dalam kegiatan belajar mengajar antara lain :

a. Metode diskusi, metode diskusi dalam pengajaran yaitu suatu cara penyajian materi pelajaran di mana siswa dibedakan kepada suatu masalah, baik berupa pertanyaan maupun berupa pernytaan yang bersifat problemik untuk dibahas atau dipecahkan oleh sisw secara bersama-sama (wahab, 2015: 212).

b. Metode ceramah, metode ceramah ialah suatu cara untuk menyampaikan bahan pelajaran dan informasi dengan cara memberitahukan secara lisan kepada orang lain yang membutuhkan (Willis, 2012:101). Metode ceramah dapat dikatakan metode pokok yang digunakan dalam proses belajar mengajar.

c. Metode problem solving (pemecahan masalah), metode ini merupakan metode yang paling tinggi tingkatanya dibandingkan dengan metode lain. Menggunakan metode ini harus mengetahui banyak teori seperti yang terjadi dalam bidang-bidang studi ilmiah.

d. Metode tanya jawab, metode tanya jawab merupakan metode yang memungkinkan terjadinya tanya jawab antara guru dengan siswa. Baik itu guru bertanya siswa menjawab atau sebaliknya siswa bertanya guru menjawab. Penggunaan metode inipun tidak terlepas dari cara-cara menggunakan metode ini. 
e. Metode demonstrasi, metode demonstrasi yaitu merupakan format belajar mengajar yang secara sengaja, menunjukkan atau memperagakan tindakan, proses atau prosedur yang dilakukan oleh guru atau orang lain kepada seluruh atu sebagian siswa (Wahab, 2015:213)

f. Sosio drama, drama sosial merupakan bermain peran yang berhubungan dengan isu sosial yang disebut dengan istilah interpersonal conflik. Drama sosial hanya membatasi diri dari pada permasalahan yang berkenaan dengan aspek sosial masyarakat. (Wahab, 2015: 213).

g. Metode karyawisata, metode karyawisata merupakan suatu cara untuk menyampaikan dan memperluas informasi kepada para pelajar dengan mengadakan kegiatan di luar sekolah, sambil menghibur mereka.

h. Metode kerja kelompok, metode kerja kelompok dapat diartikan sebagai format belajar mengajar yang menitikberatkan kepada interaksi antara anggota yang satu dengan anggota yang lain dalam satu kelompok guna menyelesaikan tugas-tugas secara bersama (Wahab, 2015:213).

d. Pendidik (guru), peran seorang guru dalam pembelajaran adalah sebagai pengelola kegiatan belajar mengajar serta bertindak sebagai fasilitator, motifator, dan peran lainya yang memungkinkan terciptanya kegiatan belajar mengajar yang efektif, sehingga tercapai tujuan dan hasil belajar yang diharapkan. Untuk itu, agar peran guru dijalankan dengan optimal, seorang guru harus menguasai materi, metode mengajar dan menggunakan pendekatan mengajar yang tepat. 
e. Siswa, menurut Djamrah anak didik adalah unsur manusiawi yang penting dalam kegiatan interaksi edukatif. Kemudian Moedjiono mengatakan bahwa dalam proses belajar mengajar siswa berperan sebagai pencari, penerima, dan penyimpan isi pelajaran yang dibutuhkan untuk mencapai tujuan (dalam Khamim, 2011:12).

f. Evaluasi, Arikunto mengatakan bahwa evaluasi merupakan kegiatan pengumpulan data untuk mengukur sejauh mana tujuan sudah tercapai. Dengan makna demikian maka anak panah berasal dari evaluasi menuju ke tujuan. Di sisi lain, jika dilihat dari langkah, dalam menyusun alat evaluasi ia mengacu pada tujuan yang sudah dirumuskan (dalam Khamim, 2011:12).

g. Alat (Sarana dan Prasarana)

Sarana merupakan hal yang sangat penting keberadanya di dalam proses belajar mengajar. Dengan adanya sarana dan prasarana yang lengkap akan semakin melancarkan proses belajar mengajar. Sarana merupakan segala sesuatu yang dapat dipakai sebagai alat dalam mencapai maksud atau tujuan (Kamus Besar Bahasa Indonesia, 2012:1226). Contoh sarana dalam pembelajaran misalnya buku pelajaran, papan tulis, spidol, kapur, pulpen, komputer, penggaris, rak dokumen, meja, kursi, OHP, dan sebagainya. Sedangkan prasarana merupakan segala sesuatu yang merupakan penunjang utama terselenggaranya suatu proses (Kamus Besar Bahasa Indonesia, 2012:1099). Contoh gedung, ruang belajar, dan tanah lapang. 


\subsubsection{Belajar}

Di dalam teori tentang belajar ini akan diuraikan mengenai pengertian belajar, jenis belajar, elemen belajar, dan faktor-faktor yang mempengaruhi belajar dan hasil belajar.

\subsubsection{Pengertian Belajar}

Belajar dimaknai sebagai usaha untuk memperoleh kepandaian atau ilmu serta berubah tingkah laku atau tanggapan yang disebabkan oleh pengalaman (Kamus Besar Bahasa Indonesia, 2012:23). Belajar ialah suatu proses usaha yang dilakukan seseorang untuk memperoleh suatu perubahan tingkah laku yang baru secara keseluruhan, sebagai hasil pengalaman sendiri dalam interaksi dengan lingkunganya (Slameto, 2010:2). Belajar merupakan sebuah proses yang kompleks yang terjadi pada semua orang yang ditandai dengan adanya perubahan perilaku pada dirinya yang menyangkut perubahan yang bersifat pengetahuan (kognitif), keterampilan (psikomotor), maupun yang menyangkut nilai dan sikap (afektif) (Siregar, 2014:3). Perubahan kemampuan dalam bereaksi relatif langgeng sebagai hasil latihan yang diperkuat. Perubahan yang langgeng dikonotasikan sebagai perubahan yang bersifat sementara seperti perubahan karena mabuk, lelah, jenuh, dan perubahan karena kematangan fisik tidak termasuk belajar Selanjutnya (Reber dalam Syah, 2010:66).

Dari pendapat para ahli di atas dapat disimpulkan bahwa arti belajar mengandung tiga unsur pokok, yaitu perubahan perilaku, pengalaman, dan perubahan dalam jangka waktu yang lama. Perubahan perilaku yang dimaksud dapat berbentuk perubahan pada aspek kognisi, afeksi, dan psikomotor. 


\subsubsection{Jenis-jenis Belajar}

Ada beberapa bentuk perilaku yang disebut sebagai belajar dalam kehidupan kita yang disebut sebagai jenis-jenis belajar. Jenis-jenis belajar menurut Wahab (2015:21) yaitu sebagai berikut.

a. Belajar arti ata-kata, belajar arti kata-kata maksudnya adalah orang mulai mengungkap arti yang terkandung dalam kata-kata yang digunakan.

b. Belajar kognitif, dalam belajar kognitif objek-objek yang ditanggapi tidak hanya yang bersifat materiil, tetapi juga bersifat tidak materil. Semakin banyak pikiran dan gagasan yang dimiliki seseorang, semakin luasnya dalam pikiran kognitif orang itu. Seseorang tidak bisa melepaskan diri dari belajar kognitif.

c. Belajar menghafal, menghafal adalah suatu aktivitas menanamkan suatu materi verbal di dalam ingatan, sehingga dapat memproduksikan (ingatan) kembali secara harfiah.

d. Belajar teoritis, belajar teoritis bertujuan untuk menempatkan semua data dan fakta (pengetahuan) dalam suatu kerangka organisasi mental, sehingga dapat dipahami dan digunakan untuk memecahkan problem, seperti terjadi dalam bidang-bidang studi ilmiah.

e. Belajar konsep, belajar konsep atau pengertian adalah satuan arti yang mewakili sejumlah objek yang mempunyai ciri-ciri yang sama.

f. Belajar kaidah, belajar kaidah adalah bila dua konsep atau lebih dihubungkan satu sama lain, terbentuk suatu ketentuan yang mempresentasikan suatu keteraturan. Kaidah adalah suatu pegangan yang tidak dapat diubah-ubah. 
g. Belajar berpikir, masalah dalam belajar terkadang ada yang harus dipecahkan sendiri, tanpa bantuan orang lain. pemecahan masalah itulah yang memerlukan pemikiran.

h. Belajar keterampilan motorik, dalam kehidupan manusia, keterampilan motorik memegang peranan sangat pokok, seorang anak kecil harus sudah menguasai berbagai keterampilan motorik.

i. Belajar estetis, belajar ini bertujuan untuk membentuk kemampuan menciptakan dan memperkaya keindahan dalam berbagai bidang kesenian.

Jadi, dapat diambil kesimpulan bahwa dengan belajar kita dapat mengetahuai sesuatu yang tidak diketahui menjadi tahu. Belajar juga memerlukan cara berpikir yang baik, itu semua dapat kita ketahui dengan belajar. Karena dengan belajar kita dapat memiliki keterampilan menggali potensi-potensi yang ada pada diri kita (Wahab, 2015:24).

\subsubsection{Elemen Belajar}

Elemen belajar merupakan bagian-bagian yang berperan penting dalam proses belajar kita. Menurut Rifa'i dan Anni (2011:84) bagian-bagian yang penting yang dapat merubah tingkah laku seseorang terbagi atas empat yaitu; a) peserta didik, peserta didik memiliki organ penginderaan yang digunakan untuk menangkap rangsangan, otak yang digunakan untuk mentransformasikan hasil penginderaan ke dalam memori yang kompleks; dan syaraf atau otot yang digunakan untuk menampilkan kinerja yang menunjukkan apa yang telah dipelajari; b) rangsangan (stimulus), proses belajar terjadi karena adanya rangsangan yang menimbulkan respon. Contoh rangsangan seperti cahaya, suara, 
warna, guru, dan sebaginya; c) memori, memori merupakan suatu sistem di dalam otak yang berfungsi untuk menyimpan berbagai kemampuan yang dimiliki oleh siswa seperti kemampuan berupa pengetahuan, keterampilan, dan sikap yang dihasilkan dari kegiatan belajar yang telah dilakukan siswa sebelumnya. Sehubungan dengan fungsi memori Santrock (2008:312) mengatakan bahwa memori membuat diri kita berkesinambungan. Tanpa memori tidak mampu menghubungkan apa yang terjadi kemarin dengan apa yang di alami sekarang. Agar memori bekerja, anak harus mengambil informasi, menyimpanya, dan kemudian mengambilnya kembali untuk suatu tujuan di kemudian hari; d) respon, respon terjadi akibat adanya rangsangan. Peserta didik yang sedang mengamati stimulus akan mendorong memori memberikan respon terhadap stimulus tersebut. Dengan kata lain respon merupakan sebuah aktivitas yang dilakukan seseorang akibat adanya rangsangan.

Dari elemen-elemen belajar dapat kita simpulkan bahwa proses belajar terjadi atas saling mempengaruhinya elemen-elemen belajar antara elemen satu dengan yang lainya.

\subsubsection{Faktor-faktor yang Mempengaruhi Belajar dan Hasil Belajar}

\section{Ansambel Musik}

Setiap orang atau guru pasti menginginkan proses dan hasil belajar yang ideal untuk anak maupun siswa. Akan tetapi tidak semua proses dan hasil belajar dapat sesuai dengan apa yang diharapkan. Sebab ada faktor-faktor yang dapat mempengaruhi proses dan hasil belajar siswa. Faktor-faktor tersebut berdasarkan 
pendapat Daryanto (2013:36) dikelompokkan menjadi dua yaitu faktor internal dan eksternal.

a. Faktor Internal. Faktor internal yaitu faktor yang ada pada diri siswa. Ada tiga jenis faktor internal yang mempengaruhi belajar dan hasil belajar siswa diantaranya yaitu faktor jasmaniah, faktor psikologi dan faktor kelelahan.

1) Faktor jasmaniah

Kondisi jasmani dapat mempengaruhi semangat dan intensitas siswa dalam mengikuti pelajaran. Ada dua jenis faktor jasmaniah yang mempengaruhi belajar diantaranya yaitu; a) faktor kesehatan, kesehatan manusia dipandang dari dua sisi yaitu kesehatan jasmani (tubuh/badan) dan kesehatan rohani (mental). Kesehatan jasmani dapat dijaga dengan rutin berolahraga dan makan teratur sedangkan kesehatan mental dapat dijaga dengan menjaga hubungan baik dengan lingkungan sosial serta melakukan aktifitas ibadah untuk menenangkan jiwanya; b) cacat tubuh, cacat tubuh dibedakan atas cacat tubuh ringan seperti kurang pendengaran, kurang penglihatan, gangguan psikomotor dan cacat tubuh yang tetap (serius) seperti buta, tuli, bisu, hilang tangan dan kaki.

2) Faktor psikologis, faktor psikologis diartikan sebagai faktor yang berhubungan dengan kejiawaan seseorang. Menurut Slameto (2010:54) ada tujuh faktor yang termasuk dalam faktor psikologis yang mempengaruhi belajar siswa diantaranya yaitu.

a. Intelegensi/kecerdasan,Setiap individu memiliki inteligensi berupa potensi biopsychogical yang berbeda. Gardner mengemukakan tujuh jenis inteligensi yaitu : musikalitas (musical intelligence), kelenturan tubuh 
(bodily-kinesthetic intelligence), logika-matematika (logical-mathematical intelligence), inteligensi dalam bidang kebahasaan (linguistic intelligence), inteligensi ruang (spatial intelligence), hubungan pribadi (interpersonal intelligence), dan intrapersonal intelligence (Gardner dalam Astuti, 2002:18).

Musikalitas merupakan jenis inteligensi yang membutuhkan kepekaan seseorang terhadap hubungan antar nada. Musikalitas ini bergantung juga pada aspek inteligensi yang lain seperti aspek kelenturan tubuh, interpersonal dan intrapersonal. Khusus untuk ansambel musik, faktor yang menentukan keberhasilan adalah kemampuan individu dan interpersonal. Kemampuan individu meliputi musikalitas yaitu kepekaan nada dan kelenturan jari, sedangkan kemampuan interpersonal adalah kemampuan dalam menyesuaikan diri dengan anggota kelompok ansambel yang lain.

b. Perhatian, perhatian dikatakan dapat mempengaruhi belajar siswa. Perhatian adalah sebuah perasaan dan keyakinan yang kuat terhadap sesuatu yang ditunjukkan dengan rasa ingin tahu yang tinggi. Apabila siswa mempunyai perhatian maka akan cepat memancing respon siswa sehingga proses belajar pada siswa akan semakin cepat.

c. Minat, minat datang dari dalam hati sanubari siswa. Dengan adanya minat seseorang dapat melakukan hal yang diminati dengan rasa senang. Menurut Dalyono (2007:49) ada tidaknya minat terhadap sesuatu pelajaran 
dapat dilihat dari cara anak mengikuti pelajaran, lengkap tidaknya catatan dan lain-lain.

d. Bakat, bakat adalah potensi/kecakapan dasar yang dibawa sejak lahir. Setiap individu mempunyai bakat yang berbeda-beda. Menurut Dalyono (2007:50) orang tua yang berkecimpung di bidang kesenian, anaknya akan mudah mempelajari seni suara, tari, dan lain-lain. Jadi, seseorang akan mudah mempelajari yang sesuai dengan bakatnya. Apabila seorang anak harus mempelajari bahan yang lain dari bakatnya ia akan cepat bosan, mudah putus asa, dan tidak senang.

e. Motif, motifasi merupakan sebuah dorongan untuk melakukan sesuatu. Semakin besar motivasi maka akan semakin besar pula ketahanan siswa dalam menghadapi tantangan dalam proses belajarnya untuk mencapai apa yang menjadi tujuan dalam belajarnya. Untuk itu, keberadaan motivasi sangat penting dalam mendukung proses belajar siswa.

f. Kematangan, Menurut Slameto (2010:58) kematangan adalah suatu tingkat/fase dalam pertumbuhan seseorang, dimana alat-alat tubuhnya sudah siap untuk melaksanakan kecakapan baru. Misalnya anak dengan kakinya sudah siap untuk berjalan, tangan dengan jari-jarinya sudah siap menulis, dengan otaknya sudah siap untuk berpikir abstrak dan lain-lain. Untuk itu sudah jelas bila belajar akan lebih berhasil jika anak sudah siap (matang).

g. Kesiapan, kesiapan adalah kesediaan untuk memberi response atau bereaksi. Kesediaan itu timbul dari dalam diri seserorang dan juga 
berhubungan dengan kematangan, karena kematangan berarti kesiapan untuk melaksanakan kecakapan (Drever dalam Slameto, 2010:59). Apabila siswa mempunyai kesiapan untuk merespon pelajaran maka akan memudahkan terjadinya proses belajar pada diri anak. Untuk itu kesiapan jelas mempengaruhi proses dan hasil belajar siswa.

h. Kelelahan, kelelahan merupakan reaksi tubuh yang terjadi akibat dari kurangnya istirahat tubuh. Dalam keadaan lelah sangat berbahaya apabila selalu dipaksa untuk mengerjakan sesuatu karena hasilnya menjadi tidak maksimal. Seperti yang dikatakan Slameto (2010:59) bahwa kelelahan dapat menimbulkan sulit berkonsentrasi dan kecenderungan untuk membaringkan tubuh.

b. Faktor ekstern, faktor eksternal yaitu faktor-faktor dari luar peserta didik yang mempengaruhi kegiatan belajar. Menurut Slameto (2010:60) faktor ekstern yang mempengaruhi kegiatan belajar siswa diantaranya yaitu faktor keluarga, faktor sekolah dan faktor masyarakat.

1) Faktor keluarga. Keluarga merupakan sebuah lingkup terkecil dari anggota masyarakat. Akan tetapi dari lingkup terkecil inilah pengaruh dalam proses pendidikan seorang siswa sangatlah besar. Dalam hal ini Slameto (2010:60) membagi empat faktor keluarga yang mempengaruhi belajar siswa diantaranya yaitu cara orang tua mendidik anak, relasi antar anggota keluarga, suasana rumah, keadaan ekonomi keluarga, pengertian dari keluarga dan latar belakang kebudayaan. 
a. Cara orang tua mendidik, mendidik akan lebih baik jika dilakukan dari hati. Mendidik hendaknya dilakukan sesuai dengan pengetahuan mendidik yang baik. Sebab, pendidikan pertama bagi seorang anak adalah dari lingkungan keluarganya. Seringnya interaksi anak dengan keluarga akan mempengaruhi cara siswa belajar di sekolah. Untuk itu, orang tua hendaknya memberikan didikan yang terbaik untuk anaknya yang akan menghantarkan anaknya dalam keberhasilan belajar.

b. Relasi antar anggota keluarga, hubungan orang tua maupun saudara seorang anak hendaknya terjalin dengan baik. Sebab, apabila hubungan baik dan saling mendukung dalam proses belajar maka akan berpengaruh positif terhadap kemajuan belajar anak/siswa.

c. Suasana rumah, suasana rumah hendaknya diciptakan dengan nyaman, tentram dan aman dari gangguan sehingga akan melancarkan proses belajar siswa.

d. Keadaan ekonomi keluarga, keadaan ekonomi keluarga berpengaruh terhadap kemajuan belajar siswa. Keadaan ekonomi yang kurang stabil akan menghambat kemajuan belajar siswa. Begitu juga apabila siswa terlahir dari keluarga yang kaya raya ada kemungkinan orang tua tidak tahan melihat anaknya belajar dengan bersusah payah sehingga kemajuan belajar anak terhambat (Slameto, 2010:64).

e. Pengertian orang tua, pengertian orang tua sangat dibutuhkan dalam mendukung proses belajar siswa. Orang tua hendaknya membantu anaknya apabila mendapatkan kesulitan dalam belajar. 
f. Latar belakang kebudayaan, kebiasaan-kebiasaan yang dilakukan orang tua akan berpengaruh terhadap proses dan hasil belajar siswa. Sebaiknya orang tua memberikan contoh kebiasaan baik ke arah yang mendukung proses belajar siswa.

2) Faktor sekolah

Sekolah sebagai tempat untuk menuntut ilmu dan belajar juga bisa menjadi faktor yang berpengaruh terhadap proses dan hasil belajar siswa. Menurut Slameto (2010:61) faktor sekolah yang mempengaruhi belajar siswa terdiri dari metode mengajar, kurikulum, hubungan guru dengan siswa, hubungan siswa dengan siswa, disiplin sekolah, alat pelajaran, waktu sekolah, standar pelajaran di atas ukuran, keadaan gedung, metode belajar, dan tugas rumah.

a. Metode mengajar, metode atau cara mengajar guru dapat mempengaruhi proses dan hasil belajar siswa. Metode mengajar guru hendaknya disesuaikan dengan materi pembelajaran dan kondisi siswa sehingga pembelajaran dapat tepat sasaran dalam mencapai tujuan pembelajaran.

b. Kurikulum, hendakanya kurikulum dibuat sesuai dengan kemampuan dan dan karakter siswa serta perencanaan yang mendetail sehingga dapat melayani belajar siswa baik secara kelompok maupun secara individual. Kurikulum yang dibuat terlalu padat, tidak sesuai dengan kemampuan rata-rata siswa, tidak sesuai dengan bakat dan minat siswa termasuk kurikulum yang tidak baik (Slameto, 2010:66). 
c. Relasi guru dengan siswa, hubungan guru dengan siswa memberi pengaruh terhadap proses belajar dan hasil belajar siswa. Sikap guru yang menyenangkan, hangat, cinta persaudaraan, tidak menakutkan, dan sejenisnya serta menghindari sikap yang tidak disukai siswa dapat memperbaiki hubungan dengan siswa. Dengan cara seperti itu siswa akan terdorong untuk rajin belajar.

d. Hubungan siswa dengan siswa; menciptakan hubungan yang baik antar siswa dapat memberikan pengaruh positif terhadap proses dan hasil belajar siswa. Hubungan yang baik antar siswa dapat melancarkan proses belajar siswa. Hubungan yang baik akan memberi dampak saling menghormati, menyayangi, dan menyemangati antara satu dengan yang lainya. Ini penting untuk proses belajar siswa. Hubungan siswa yang dipenuhi dengan pertengkaran, persaingan yang tidak sehat akan menghambat proses belajar siswa.

e. Disiplin sekolah; kedisiplinan di sekolah mempengaruhi sikap siswa dalam belajar. Disiplin di sekolah merupakan suatu yang wajib ditegakkan. Sebab dengan disiplinlah nilai pendidikan akan terwujud. Dengan disiplin diharapkan tujuan pembelajaran dapat tercapai. Banyak contoh tidak terlaksananya disiplin di sekolah disebabkan karena murid-murid liar, sering terlambat datang, tugas yang diberikan tidak dilaksanakan, kewajibanya dilalaikan, sekolah berjalan tanpa kendali, dan sebagainya.

f. Alat pelajaran; alat pelajaran mempunyai peran penting dalam proses pembelajaran. Alat pelajaran dapat membantu proses pembelajaran 
menjadi lebih baik dan lebih optimal. Alat-alat yang dibutuhkan dalam pembelajaran misalnya papan tulis, penghapus, spidol, proyektor, LKS dan sebagainya. Dalyono (2007:244) mengatakan timbulnya alat pelajaran akan menentukan; 1) perubahan metode mengajar guru; 2) segi dalamnya ilmu pengetahuan pada pikiran anak; 3) memenuhi tuntutan dari bermacam-macam tipe anak.

g. Waktu sekolah; waktu sekolah berpengaruh terhadap proses belajar dan hasil belajar siswa. Waktu sekolah yang optimal untuk belajar adalah pagi hari sebab kondisi fikiran masih fresh dan energi masih terkumpul.

h. Standar pelajaran di atas ukuraan, pelajaran hendaknya disesuaikan dengan ukuran kemampuan siswa. Standar pelajaran yang sesuai dengan kemampuan siswa akan lebih mudah dikuasai oleh siswa dan tujuan pembelajaran dapat mudah tercapai. Apabila guru terlalu memaksakan siswa untuk menguasai pelajaran diatas kemampuan rata-rata mereka maka pembelajaran akan sulit untuk dikuasai dan tujuan pembelajaran menjadi tidak tercapai.

i. Keadaan gedung, keadaan gedung untuk belajar hendaknya layak untuk digunakan belajar. Keadaan gedung yang rusak akan menghambat proses belajar mengajar. Gedung yang layak untuk belajar misalkan kondisinya aman dari kebocoran, ventilasi udaranya cukup dan suasananya tidak bising sehingga nyaman untuk belajar.

j. Metode belajar, metode belajar siswa sangat mempengaruhi proses belajar siswa. Dengan metode belajar yang tepat maka siswa dapat lebih mudah 
memahami bahan pelajaran yang harus dikuasai. Metode belajar yang kurang baik misalkan metode belajar kebut semalam. Semua materi dipelajari dalam semalam pada malam sebelum ujian dilaksanakan. Metode belajar seperti ini tentu sangat tidak efektif dan akan berakibat pada hasil belajar yang tidak optimal.

k. Tugas rumah, tugas rumah yang terlalu banyak akan menyita waktu dan mengurangi aktivitas siswa di rumah dan di lingkungan masyarakat. Hendaknya guru tidak terlalu banyak memberi tugas rumah kepada siswa.

3) Faktor masyarakat

Masyarakat dan bentuk kehidupanya juga dapat mempengaruhi proses belajar di dalam diri seorang siswa. Menurut Slameto (2010:61) faktor-faktor yang mempengaruhi belajar siswa di lingkungan masyarakat yaitu; a) kegiatan siswa dalam masyarakat, siswa yang aktif di masyarakat akan berkembang kepribadianya akan tetapi siswa juga harus dibatasi agar tidak terganggu belajarnya. Jika mungkin sebaiknya siswa memilih kegiatan yang mendukung belajar. Kegiatan itu misalnya kursus bahasa inggris, kelompok diskusi, PKK remaja dan sebagainya; b) media masa, media masa memberikan pengaruh terhadap proses belajar siswa. Media masa yang memberikan banyak pengetahuan-pengetahuan positif dapat mendukung proses belajar siswa. Dan sebaliknya media masa yang memberikan tontonan negatif dapat menghambat proses belajar siswa; c) bentuk kehidupan masyarakat, bentuk kehidupan masyarakat yang positif / lingkungan yang baik akan memberikan pengaruh yang baik terhadap siswa. Misal dalam 
sebuah lingkungan terdapat banyak orang berpendidikan dan senang terhadap belajar maka dapat memberi dampak positif terhadap belajar siswa. Siswa menjadi terdorong untuk belajar lebih giat lagi. Berbeda apabila lingkungan tersebut banyak orang yang tidak bersekolah, maka siswa akan bergaul dan ikut terbawa keadaan sehingga menjadi malas untuk belajar.

Dari penjelasan di atas dapat disimpulkan bahwa setiap orang atau siswa mengalami beberapa faktor yang dapat mendukung maupun menghambat proses belajarnya. Baik itu dari lingkungan keluarga, masyarakat, maupun sekolah. Seorang guru yang kompeten dan profesional diharapkan mampu mengantisipasi kemungkinan-kemungkinan munculnya kelompok siswa yang menunjukkan gejala kegagalan dengan berusaha mengetahui dan mengatasi faktor yang menghambat proses belajar mereka.

\subsubsection{Hasil Belajar}

Di dalam teori tentang hasil belajar ini akan diuraikan mengenai pengertian hasil belajar, jenis hasil belajar dan macam-macam hasil belajar.

\subsubsection{Pengertian Hasil Belajar}

Menurut Purwanto (2009:47) hasil belajar merupakan perolehan dari proses belajar siswa sesuai dengan tujuan pengajaran. Menurut Rifa'i dan Anni, (2011:97) hasil belajar merupakan perubahan perilaku yang diperoleh peserta didik setelah mengalami kegiatan belajar. Perolehan aspek-aspek perubahan perilaku tersebut bergantung pada apa yang dipelajari oleh peserta didik. Menurut Sudjana (2014:3) hasil belajar siswa pada hakikatnya adalah perubahan tingkah laku yang mencangkup bidang kognitif, afektif, dan psikomotorik 
Dari beberapa pendapat di atas, dapat diambil kesimpulan bahwa hasil belajar merupakan perubahan perilaku yang mencangkup bidang kognitif, afektif, dan psikomotorik yang diperoleh peserta didik setelah mengalami kegiatan belajar.

\subsubsection{Jenis-jenis Hasil Belajar}

Bloom dalam Rifa'i dan Anni (2011:86) membagi jenis-jenis hasil belajar menjadi tiga yaitu; a) ranah kognitif, ranah kognitif ditandai dengan adanya pengetahuan, kemampuan, dan kemahiran intelektual. Ranah kognitif ada enam kategori yaitu pengetahuan(knowledge), pemahaman (comprehension), penerapan (application), analisis (analysis), sintesis (synthesis), dan penilaian (evaluation); b) ranah afektif, hasil belajar afektif yaitu berhubungan dengan perasaan, sikap, minat, dan nilai. Ranah afektif terdiri dari lima kategori yaitu penerimaan (receiving), penanggapan (responding), penilaian (valuing), pengorganisasian (organization), pembentukan pola hidup (organization by a value complex); c) ranah psikomotorik, hasil belajar psikomotorik berhubungan dengan kemampuan fisik seperti keterampilan fisik, keterampilan motorik dan syaraf, manipulasi objek, dan `koordinasi syaraf. Ranah psikomotorik terdiri dari tujuh kategori yaitu persepsi (perception), kesiapan (set), gerakan terbimbing (guided respons), gerakan terbiasa (mechanism), gerakan kompleks (complex overt respons), penyesuaian (adaptation), dan kreatifitas (originality) (Elizabet Simpson dalam Rifa'i dan Anni, 2011:89) 


\subsubsection{Macam-macam hasil belajar}

Gagne dalam Aunurrahman (2012:47) membagi macam-macam hasil belajar menjadi lima yaitu sebagai berikut; a) keterampilan intelektual, atau pengetahuan prosedural yang mencangkup belajar konsep, prinsip dan pemecahan masalah yang diperoleh melalui penyajian materi di sekolah; b) strategi kognitif, yaitu kemampuan untuk memecahkan masalah-masalah baru dengan jalan mengatur proses internal masing-masing individu dalam memperhatikan, belajar, mengingat, dan berpikir; c) informasi verbal, yaitu kemampuan untuk mendeskripsikan sesuatu dengan kata-kata dengan jalan mengatur informasiinformasi yang relevan; d) keterampilan motorik, yaitu kemampuan untuk melaksanakan dan mengkoordinasikan gerakan-gerakan yang berhubungan dengan otot; e) sikap, yaitu suatu kemampuan internal yang mempengaruhi tingkah laku seseorang yag didasari oleh emosi, kepercayaan-kepercayaan serta faktor intelektual.

\subsubsection{Musik Ansambel}

Teori yang berkenaan dengan ansambel dalam penelitian ini akan diuraikan mengenai pengertian ansambel, jenis-jenis ansambel, dan proses belajar ansambel musik.

\subsubsection{Pengertian Ansambel}

Salah satu bentuk cara memainkan alat musik adalah ansambel. Musik ansambel adalah bermain musik secara bersama-sama dengan menggunakan beberapa alat musik tertentu serta memainkan lagu-lagu dengan aransemen sederhana. Menurut Banoe dalam Afrizal (2015 : 26) Ensemble berasal dari 
bahasa perancis yangberarti kelompok musik dalam satuan kecil atau permainan bersama dalam satuan kecil alat musik. Senada dengan pendapat di atas, Syafiq dalam Afrizal (2015:26) mengatakan bahwa ansambel adalah kelompok kegiatan seni musik yang dilakukan lebih dari satu orang, dan tampil sebagai hasil kerjasama di bawah pimpinan seorang pelatih. Kemudian lebih diperjelas lagi oleh Ardianto dalam Kurniawati (2007:12) yang mengatakan bahwa ansambel dalam musik adalah permainan bersama dalam kelompok kecil dengan jumlah pemain berkisar antara dua sampai lima belas orang.

Dari beberapa pendapat yang dikemukakan di atas dapat disimpulkan bahwa ansambel adalah salah satu bentuk cara memainkan alat musik secara bersama-sama dengan menggunakan beberapa alat musik tertentu serta memainkan lagu-lagu dengan aransemen sederhana yang tampil sebagai hasil kerjasama di bawah pimpinan seorang pelatih dengan dengan jumlah pemain berkisar antara dua belas sampai lima belas orang.

\subsubsection{Jenis-jenis Ansambel}

Musik ansambel dapat dikelompokkan berdasarkan penyajianya dan berdasarkan jenis alat musiknya. Berdasarkan penyajianya, musik ansambel di kelompokkan menjadi dua yaitu musik ansambel sejenis dan musik ansambel campuran. Menurut Setianingsih dkk. dalam Kurniawati (2007:14) ansambel sejenis yaitu bermain musik secara bersama-sama dengan menggunakan satu jenis alat musik dalam jumlah banyak. Dimana kebanyakan musik ansambel sejenis disebutkan menurut alat musiknya misalnya ansambel musik gitar, ansambel muik recorder, pianika, alat musik ritmis, atau biola. Adapun ansambel campuran yaitu 
bemain musik secara bersama-sama dalam sebuah kelompok dengan menggunakan alat musik melodis, harmonis, dan ritmis yang dimainkan secara bersamaan. Kebersamaan ini sangat penting untuk menghasilkan sajian musik yang terpadu dan enak didengar. Tempo yang digunakan harus stabil untuk memberikan kedisiplinan dan ketenangan jiwa, terutama bagi pemain musik.

Menurut peranan dan fungsinya alat-alat musik yang digunakan dalam bermain musik ansambel dikelompokkan menjadi tiga macam, yaitu alat musik melodis, alat musik ritmis, dan alat musik harmonis. Alat musik ritmis merupakan alat yang digunakan untuk memberikan irama (ritme) tertentu dalam pergelaran musik. Hal ini berhubungan dengan ketukan dan birama, misalnya : kendang, tifa, tamborin, rebana, drum set, timpani, triangel, bass, bongo, simbal, gong, dan lain sebagainya. Adapun alat musik melodis yaitu alat musik yang digunakan untuk memainkan rangkaian nada atau melodi sebuah lagu. Misalnya : biola, recorder, flute, dan sebagainya. Sedangkan alat musik harmonis yaitu alat musik yang berperan sebagai pembawa panduan nada (accord) misalnya gitar pengiring, kolintang, ukulele, banjo dan lain-lain.

\subsubsection{Proses Belajar Ansambel Musik}

Menurut Kurniawati, (2007:16) proses belajar ansambel meliputi tiga bagian yaitu; a) pembagian kelompok, pembagian kelompok ansambel musik ditentukan oleh guru seni musik. Misalkan setiap kelompok berjumlah tujuh sampai delapan siswa yang terdiri dari tiga pemain pianika, dua pemain rekorder, satu pemainn gitar akustik, satu pemain triangel, dan satu pemain castanet; b) penempatan dan pemilihan alat musik, langkah ini dilakukan oleh guru seni musik 
dengan mempertimbangkan keahlian dan potensi yang dimiliki oleh masingmasing siswa dalam bermain musik. Terutama penempatan alat musik gitar akustik; c) pembelajaran setiap instrumen (alat musik), pembelajaran instrumen atau alat musik dilakukan oleh guru secara berkelompok. Siswa dalam kelompok sudah mengetahui posisi masing-masing sesuai dengan alat musik yang dimainkan. Tiap kelompok diberi pengarahan oleh guru tentang membaca partitur lagu, memainkan alat musik dengan posisi jari yang benar, memperhatikan tempo lagu, dan sebagainya. 


\section{BAB III \\ METODE PENELITIAN}

\subsection{Jenis Penelitian}

Jenis penelitian yang digunakan dalam penelitian ini adalah penelitian kualiatif deskriptif dengan menggunakan analisis Mix Methods (metode kombinasi). Metode kualitatif yaitu prosedur penelitian yang menghasilkan data deskriptif berupa kata-kata tertulis atau lisan dari orang-orang dan perilaku yang dapat diamati (Bogdan dan Taylor dalam Margono, 2010:36). Metode penelitian kualitatif dapat diartikan sebagai metode penelitian yang berlandaskan filsafat pospositivisme, digunakan untuk meneliti pada kondisi obyek yang alamiah, (sebagai lawanya adalah eksperimen) dimana peneliti sebagai instrumen kunci, tekhnik pengumpulan data dilakukan secara triangulasi (gabungan), analisis data bersifat induktif/kualitatif, dan hasil penelitian kualitatif lebih menekankan makna dari pada generalisasi (Sugiyono, 2014:1). Deskriptif yaitu menggambarkan keadaan subyek/obyek penelitian yang sedang berlangsung, berdasarkan faktafakta yang tampak atau sebagaimana adanya (Mc Millan dan Schumacher dalam Sukmadinata, 2013:96).

Mix Methods yaitu penggabungan dua metode (kualitatif dan kuantitatif) dalam satu penelitian. Mix Methods dalam penelitian ini digunakan untuk menganalisis data-data hasil penelitian dalam menjawab dua rumusan masalah yang berbeda. Data yang berhubungan dengan pembelajaran ansambel dianalisis menggunakan metode kualitatif sedangkan data yang berkaitan dengan faktor- 
faktor yang memengaruhi hasil belajar ansambel dianalisis menggunakan metode kuantitatif.

\subsection{Lokasi dan Sasaran Penelitian}

\subsubsection{Lokasi Penelitian}

Lokasi penelitian ini dilakukan di SMPN 22 Semarang, kelurahan Nongkosawit, kecamatan Gunung Pati. Dipilihnya lokasi tersebut karena SMPN 22 Seamrang mempunyai kegiatan pembelajaran ansambel gamelan jawa pada kelas VIII. Dengan demikian penulis dapat memperoleh data yang tepat baik melalui wawancara dengan guru seni musik maupun dengan observasi langsung di sekolah tersebut.

\subsubsection{Sasaran Penelitian}

Sasaran dalam penelitian ini sesuai dengan masalah yang dikemukakan ialah pelaksanaan pembelajaran ansambel yang meliputi langkah apa saja yang harus dilakukan guru pada tahap persiapan, pelaksanaan pembelajaran, dan sesudah tahap pembelajaran atau evaluasi, penggunaan metode, materi pembelajaran yang disajikan, pengelolaan kelas serta faktor-faktor yang mempengaruhi hasil belajar ansambel siswa.

\subsection{Sumber Data}

Sumber data dalam penelitian ini berasal dari dua sumber, yaitu sumber primer dan sumber sekunder. Sumber primer adalah sumber data yang langsung memberikan data kepada pengumpul data, dan sumber sekunder merupakan sumber yang tidak langsung memberikan data kepada pengumpul data, misalnya lewat orang lain atau lewat dokumen (Sugiyono, 2010:308). 
Sumber data primer dalam penelitian ini diperoleh dari hasil wawancara secara langsung kepada kepala sekolah SMPN 22 Semarang, guru mata pelajaran seni musik di SMPN 22 Semarang, siswa kelas VIII C di SMPN 22 Semarang dan kepala TU SMPN 22 Semarang. Data sekunder diperoleh dari jurnal imliah, majalah ilmiah, buku cetak dan lain sebagainya.

\subsection{Teknik Pengumpulan Data}

Teknik pengumpulan data dalam penelitian ini menggunakan teknik wawancara, observasi, angket, dokumentasi dan angket.

\subsubsection{Teknik Wawancara}

Wawancara adalah pertemuan dua orang untuk bertukar informasi dan ide melalui tanya jawab, sehingga dapat dikonstruksikan makna dalam suatu topik tertentu (Esterberg dalam Sugiyono, 2014:72). Esterberg dalam Sugiyono (2014:73) mengemukakan beberapa macam wawancara, yaitu wawancara tersetruktur, semi terstruktur, dan tidak terstruktur. Wawancara terstruktur (Structured interview) digunakan sebagai teknik pengumpulan data, bila peneliti atau pengumpul data telah mengetahui dengan pasti tentang informasi apa yang akan diperoleh. Wawancara Semi terstruktur (Semisructure Interview) sudah termasuk dalam in-dept interview, dimana dalam pelaksanaannya lebih bebas bila dibandingkan dengan wawancara terstruktur. Wawancara tidak berstruktur (Unstructured intervie) ialah wawancara yang bebas dimana peneliti tidak menggunakan pedoman wawancara yang telah tersusun secara sistematis dan lengkap untuk mengumpulkan datanya. 
Berdasarkan pengertian tersebut, wawancara yang digunakan dalam penelitian ini adalah wawancara terstruktur yaitu pewawancara membawa pedoman wawancara yang mencangkup garis besar tentang hal yang akan diteliti. Wawancara tersebut ditujukan kepala sekolah, guru seni musik, siswa, dan kepala TU. Wawancara akan difokuskan pada pembelajaran ansambel seni musik. Dan untuk guru seni musik wawancara difokuskan pada apa yang dipersiapkan sebelum pembelajaran ansambel, dan bagaimana gambaran pelaksanaan pembelajaran ansambel. Wawancara kepada siswa dilaksanakan setelah pembelajaran ansambel melalui tahap evaluasi.

\subsubsection{Teknik Studi Dokumen}

Studi dokumenter (documentary study) merupakan suatu tekhnik pengumpulan data dengan menghimpun dan menganalisis dokumen-dokumen, baik dokumen tertulis, gambar, maupun elektronik. Dokumen-dokumen yang telah didapatkan kemudian isinya dianalisis (diurai), dibandingkan, dan dipadukan (sintesis) membentuk satu hasil kajian yang sistematis, padu dan utuh. Jadi, studi dokumen tidak sekadar mengumpulkan dan menuliskan atau melaporkan dalam bentuk kutipan-kutipan tentang sejumlah dokumen, akan tetapi yang dilaporkan dalam penelitian adalah hasil analisis terhadap dokumen-dokumen tersebut (Sukmadinata 2013:222). Dalam teknik studi dokumen ini peneliti mencari dokumen tertulis seperti RPP, data profil sekolah, data siswa kemudian gambar dalam bentuk foto, serta data dalam bentuk audio visual. 


\subsubsection{Teknik Observasi}

Teknik observasi adalah kegiatan pengamatan dan pemusatan perhatian terhadap sesuatu objek dengan menggunakan seluruh alat indera yang dapat dilakukan melalui indera penglihatan, penciuman, pendengaran, peraba, dan pengecap (Arikunto dalam Priyandaru, 2011:51). Observasi atau pengamatan didefinisikan sebagai perhatian yang terfokus terhadap kejadian, gejala atau sesuatu. Observasi partisipan adalah observasi yang dilakukan oleh peneliti yang berperan sebagai anggota yang berperan serta dalam kehidupan masyarakat topik penelitian. Observasi non partisipan adalah observasi yang menjadikan peneliti sebagai penonton atau penyaksi terhadap gejala atau kejadian yang menjadi topik penelitian (Emzir, 2010:37).

Dalam penelitian ini observasi dilakukan secara langsung oleh peneliti dan peneliti sebagai pengamat. Untuk itu, observasi yang digunakan ialah observasi nonpartisipan. Observasi dilaksanakan dengan alat observasi berupa pedoman observasi. Observasi pada penelitian ini dilaksanakan selama dua kali. Observasi yang pertama peneliti mendatangi sekolah dan menemui guru seni musik untuk menanyakan jadwal pembelajaran ansambel dilaksanakan, lokasi kelas observasi, dan menanyakan persiapan apa yang dilakukan sebelum proses belajar mengajar ansambel berlangsung. Peneliti juga menemui petugas TU guna melengkapi data penelitian untuk mengumpulkan berbagai informasi mengenai kondisi sekolah. Observasi yang kedua peneliti mengamati jalanya proses pembelajaran ansambel seni musik di kelas VIII C dengan menggunakan pedoman observasi dan alat 
perekam audio visual agar dapat diputar kembali dan menjadi dokumentasi bagi penelitian.

Berdasarkan pedoman observasi, peneliti mengambil data mengenai; (a) kondisi lingkungan sekolah dan kondisi lingkungan sekitar sekolah; (b) situasi proses belajar mengajar mata pelajaran seni musik materi ansambel yang meliputi aktivitas guru dan siswa dalam kegiatan belajar mengajar dari awal hingga akhir pembelajaran; (c) kurikulum pembelajaran seni musik; (d) sarana dan prasarana yang tersedia untuk belajar seni musik; (e) jenis media yang digunakan dalam pembelajaran seni musik pada saat proses pembelajaran ansambel; (f) alat-alat yang digunakan dalam proses pembelajaran ansambel; (g) proses pelaksanaan penggunaan metode dan media dalam pembelajaran ansambel seni musik. Observasi dilaksanakan dengan bantuan catatan lapangan, alat perekam audio visual dan foto camera.

\subsubsection{Teknik Angket}

Angket merupakan teknik pengumpulan data yang dilakukan dengan cara memberi seperangkat pertanyaan atau pernyataan tertulis kepada responden untuk dijawabnya (Sugiyono, 2008:142). Dalam penelitian ini, angket yang diberikan kepada siswa berupa pernyataan-pernyataan yang diisi sesuai dengan fakta. Angket ini berfungsi untuk mengetahui faktor-faktor apa saja yang memengaruhi hasil belajar ansambel siswa. Angket yang digunakan peneliti adalah angket yang berupa pernyataan tertutup, siswa tinggal memlilih jawaban yang tersedia. Angket tertutup adalah angket yang disusun dengan menyediakan pilihan jawaban lengkap sehingga responden hanya tinggal memberi tanda pada jawaban yang 
dipilih (Arikunto, 2013:42). Hal ini dilakukan mengingat jumlah responden cukup banyak yaitu tiga puluh satu orang siswa. Lembar angket terdiri dari 20 butir pertanyaan. Dalam setiap butir pernyataan terdiri dari empat pilihan jawaban. Empat pilihan jawaban yaitu : SL(selalu), SR(sering), KK(kadang-kadang), TP(tidak pernah). Adapun angket dibagikan di luar jam pelajaran agar tidak mengganggu proses belajar mengajar.

Berikut kisi-kisi angket faktor-faktor yang memengaruhi hasil belajar ansambel siswa.

Tabel 3.1 Kisi-kisi Angket Faktor-faktor yang Memengaruhi Hasil Belajar Ansambel Seni Musik Kelas VIII C

\begin{tabular}{|c|l|c|c|}
\hline No & \multicolumn{1}{|c|}{ Indikator } & Nomor Item & Jumlah \\
\hline 1. & Kesehatan & $10,13,14$ & 3 \\
\hline 2. & Kecerdasan & 18 & 1 \\
\hline 3. & Perhatian & 11 & 1 \\
\hline 4. & Minat & $4,12,19$ & 3 \\
\hline 5. & Bakat & 2 & 1 \\
\hline 6. & Motif & 3 & 1 \\
\hline 7 & Metode belajar & 29 & 1 \\
\hline 8. & Kesiapan & 17 & 1 \\
\hline 9. & Kelelahan & 21 & 1 \\
\hline 10. & Hubungan siswa dengan siswa & 27 & 1 \\
\hline 11. & Kurikulum & 25 & 1 \\
\hline 12. & Disiplin sekolah & 9 & 1 \\
\hline 13. & Alat pelajaran & 5,15 & 1 \\
\hline 14. & Keadaan gedung & 6 & 1 \\
\hline 15. & Cara orang tua mendidik & 8 & 1 \\
\hline 16. & Relasi anggota keluarga & 22,28 & 1 \\
\hline 16 & Suasana rumah & 16 & 2 \\
\hline 17. & Keadaan ekonomi keluarga & & 1 \\
\hline 18. & Pengertian orang tua & 24 & 1 \\
\hline 19. & Metode mengajar & & 1 \\
\hline 20. & Relasi guru dengan siswa & 23 & 1 \\
\hline & & & 1 \\
\hline
\end{tabular}




\begin{tabular}{|c|l|l|l|}
\hline 21. & Tugas rumah & 30 & 1 \\
\hline 22. & Standar pelajaran di atas ukuran & 20 & 1 \\
\hline 23. & Kegiatan siswa dalam masyarakat & 31 & 1 \\
\hline 24. & Media masa & 32 & 1 \\
\hline 25 & Bentuk kehidupan masyarakat & 33 & 1 \\
\hline
\end{tabular}

\subsection{Teknik Pemeriksaan Keabsahan Data}

Menurut Sumaryanto dalam Fadlila (2015:40) terdapat tujuh teknik yang dapat digunakan oleh peneliti untuk memeriksa keabsahan data kualitatif yang diperoleh, yaitu; (1) perpanjangan keikutsertaan, (2) ketekunan pengamatan, (3) triangulasi, (4) pemeriksaan sejawat, (5) analisis kasus negatif, (6) pengecekan kecukupan referensi, dan (7) pengecekan anggota. Didalam penelitian ini peneliti menggunakan teknik triangulasi untuk menguji atau memeriksa keabsahan data yang telah diperoleh dilapangan. Triangulasi berarti penemuan informasi dari satu sumber yang menggunakan berbagai cara, dan juga dari berbagai sumber dengan menggunakan satu cara. Peneliti menggunakan triangulasi agar mendapatkan data yang lebih konsisten, tuntas, dan pasti. Peneliti menggunakan sumber data yang telah diperoleh dilapangan seperti dari dokumen, hasil wawancara, dan dari hasil observasi dilapangan.

\subsection{Teknik Analisis Data}

Analisis data adalah proses mencari dan menyusun secara sistematis data yang diperoleh dari hasil wawancara, catatan lapangan, dan bahan-bahan lain sehingga dapat mudah difahami, dan temuanya dapat diinformasikan kepada orang lain. Analisis data dilakukan dengan mengorganisasikan data, mejabarkanya ke dalam unit-unit, melakukan sintesa, menyusun ke dalam pola, memilih mana 
yang penting dan yang akan dipelajari, dan membuat kesimpulan yang dapat diceritakan kepada orang lain (Bogdan dalam Sugiyono, 2014:88). Aktivitas dalam analisis dilakukan secara interaktif dan berlangsung secara terus menerus sampai tuntas, sehingga datanya sudah jenuh. Aktivitas dalam analisis data yaitu data collection, data reduction, data display, dan data conclusion drawing/verification. Model interaktif dalam analisis data ditunjukkan pada bagan berikut.

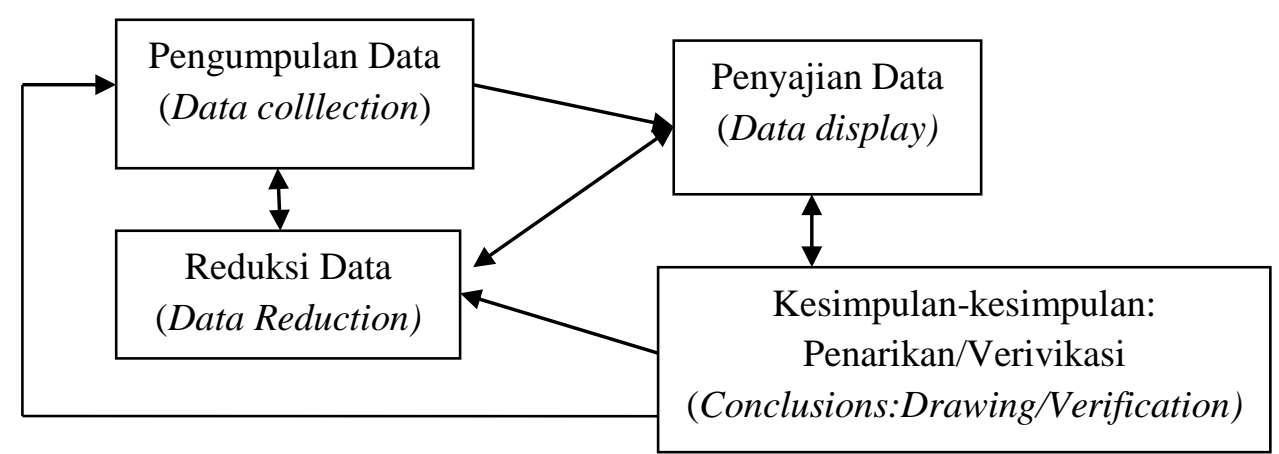

Bagan 3.1 Komponen-komponen Analisis Data : Model Interaktif Sumber : Analisis Data Kualitatif (Miles \& Huberman, 2014)

\subsubsection{Pengumpulan Data (Data colllection)}

Dalam penelitian ini, penulis mengumpulkan data di lapangan melalui kegiatan wawancara, angket, observasi, dan dokumentasi.

\subsubsection{Reduksi Data (Data Reduction)}

Reduksi data merupakan proses berfikir sensitif yang memerlukan kecerdasan dan keluasan serta kedalaman wawasan yang tinggi (Sugiyono, 2014:93). Untuk mereduksi data, peneliti akan memfokuskan pada tujuan yang akan dicapai. Tujuan yang sebenarnya adalah pada temuan-temuan dilapangan. Temuan tersebut merupakan temuan yang berbeda yang belum ada sebelumnya dan itulah yang menjadi pokok perhatian dalam mereduksi data. 
Setiap temuan yang didapatkan oleh peneliti dilapangan dianalisis dengan cara didokumentasikan dan dicatat sebagai data untuk kemudian di tindak lanjuti setelah menjadi data. Dalam penelitian ini, penulis menganalisis temuan-temuan yang didapat dilapangan dari hasil wawancara, hasil observasi, dan hasil dokumentasi.

\subsubsection{Penyajian Data (Data Display)}

Penyajian data merupakan kelanjutan dari proses analisis data dan reduksi, yaitu dengan cara menyusun data-data yang telah terkumpul setelah di reduksi. Menurut Sugiyono (2014:95) menyatakan bahwa yang paling sering digunakan untuk menyajikan data dalam penelitian kualitatif adalah dengan teks yang bersifat naratif.

\subsubsection{Penarikan Kesimpulan dan Verifikasi (Conclusions:Drawing/Verification)}

Langkah selanjutnya dalam analisis data kualitatif adalah penarikan kesimpulan dan verifikasi. Menurut Sugiyono (2014:99) kesimpulan dalam penelitian kualitatif merupakan temuan yang dapat berupa deskripsi atau gambaran suatu objek yang sebelumnya masih remang-remang atau gelap sehingga setelah diteliti menjadi jelas, dapat berupa hubungan kausal atau interaktif, hipotesis atau teori. Penulis dalam penelitian ini mengambil kesimpulan dari data-data yang telah didapat dan yang berhubungan dengan aspek analisis data yaitu dari mulai pengumpulan data, reduksi data, sampai dengan penyajian data yang telah disusun menjadi satu fokus penelitian.

Adapun analisis data angket, peneliti menggunakan teknik analisis secara kuantitatif yang disebut deskripsi analisis yaitu menggambarkan apa adanya. Hasil 
pesentase skor tiap butir pernyataan dikualifikasikan menggunakan tabel kualifikasi sebagai berikut:

\subsubsection{Tabel Frekuensi}

Membuat tabel frekuensi dilengkapi dengan presentase. Dalam hal ini penulis menggunakan rumus sebagai berikut:

Keterangan:

$$
\begin{array}{ll}
\boldsymbol{p} & \\
= & \frac{F}{N} \\
&
\end{array}
$$

$\mathrm{P} \quad=$ Jumlah jawaban yang diharapkan

$\mathrm{F} \quad=$ Number of cases (jumlah frekuensi/banyak individu)

$\mathrm{N} \quad=$ Angka presentase

(Sudjono dalam Lutfiyah, 2014:42)

\subsubsection{Kualifikasi Hasil Presentase Skor Tiap Butir Pertanyaan}

Setelah dipresentasekan menggunakan rumus presentase, hasil presentase skor tiap butir pernyataan dikualifikasikan menggunakan tabel kualifikasi (Arikunto dalam Luthfiah, 2014:41). Kualifikasi digunakan untuk menempatkan presentase tiap butir soal dalam tingkatan. Kualifikasi dimulai dari kualifikasi tertinggi yaitu baik sekali apabila perolehan presentase kurang dari atau sama dengan $100 \%$, kemudian kualifikasi baik diperoleh jika presentase hasil jawaban kurang dari atau sama dengan $80 \%$, lalu kualifikasi cukup diperoleh jika presentase hasil jawaban kurang dari atau sama dengan 60\%. Selanjutnya kualifikasi kurang diperoleh jika presentase hasil jawaban kurang dari atau sama 
40\%. Kualifikasi terahir yaitu sangat kurang jika presentase hasil jawaban kurang dari atau sama dengan $20 \%$.

Tabel 3.2 Kualifikasi Hasil Presentase Skor Tiap Butir Pertanyaan

\begin{tabular}{|c|c|}
\hline Presentase $\mathbf{( \% )}$ & Kualifikasi \\
\hline $80 \%<$ presentase $\leq 100 \%$ & Baik sekali \\
\hline $60 \%<$ presentase $\leq 80 \%$ & Baik \\
\hline $40 \%<$ presentase $\leq 60 \%$ & Cukup \\
\hline $20 \%<$ presentase $\leq 40 \%$ & Kurang \\
\hline $0 \%<$ presentase $\leq 20 \%$ & Kurang sekali \\
\hline
\end{tabular}




\section{BAB IV}

\section{HASIL PENELITIAN DAN PEMBAHASAN}

\subsection{Gambaran Umum Lokasi Penelitian}

Gambaran umum dari penelitian ini terdiri dari lokasi penelitian, sejarah berdirinya lokasi penelitian, prestasi siswa, kegiatan ekstrakurikuler, sarana dan prasarana sekolah, visi dan misi sekolah, tanaga pengajar SMPN 22 Semarang, struktur organisasi sekolah, siswa SMPN 22 Semarang, tenaga administrasi dan tenaga pendukung SMPN 22 Semarang.

\subsubsection{Lokasi}

SMPN 22 Semarang berlokasi di Jalan Raya Gunungpati, Kelurahan Nongkosawit, Kecamatan Gunung Pati. SMPN 22 Semarang berdiri di atas tanah seluas $\pm 11.204 \mathrm{~m}^{2}$. Letak SMPN 22 Semarang sangat strategis karena dekat dengan pemukiman warga. Akses menuju sekolahpun sangat mudah karena letak sekolah berada sangat dekat dengan jalan raya sehingga mudah dijangkau oleh alat transportasi umum maupun pribadi.

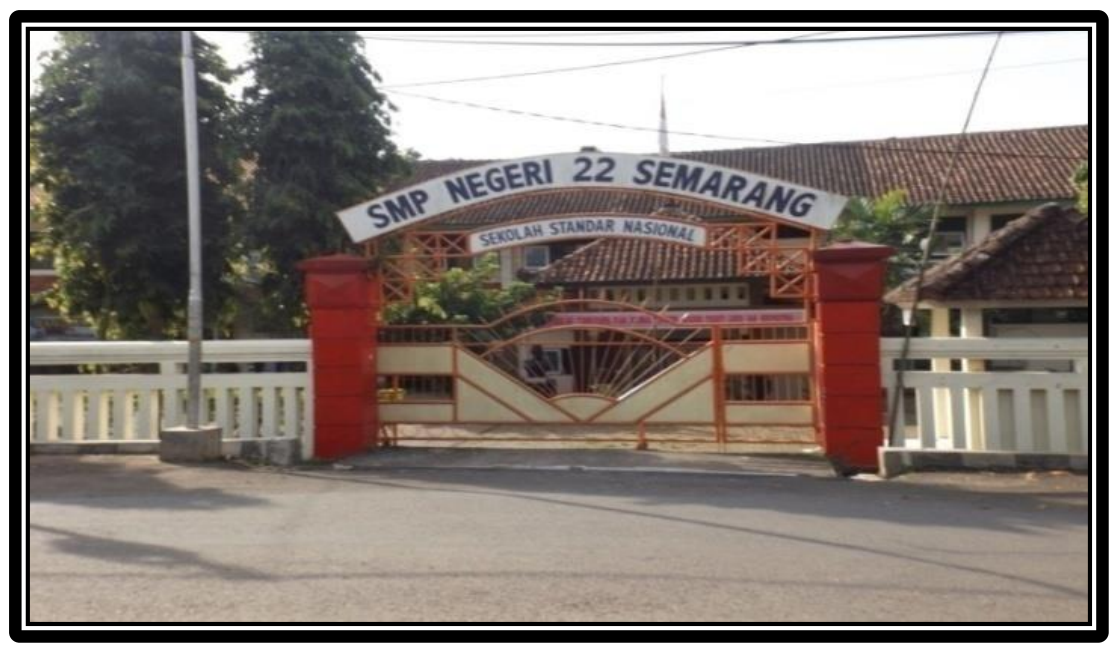

Gambar 4.1 Pintu Gerbang SMPN 22 Semarang

(Dokumentasi:Yulfiani, Juni 2017 


\subsubsection{Sejarah}

SMPN 22 Semarang berdiri sejak tahun 70an. Berdasarkan informasi yang diperoleh di Web Site SMPN 22 Semarang, pendiri SMPN 22 Semarang terdiri dari unsur Tipika dan unsur Dinas Pendidikan di Kecamatan Gunungpati. Semula bernama SMP Pemerintah daerah Gunungpati dibangun 12 November 1972 di atas tanah milik bondo deso yang terletak di Plalangan dengan luas $1140 \mathrm{~m}^{2}$. Tanah bondo deso tersebut diserahkan guna pembangunan SMP Negeri pada rembug desa dan perwakilan dari lembaga pemerintah desa dan semua pihak lakilaki dan perempuan.

Kemudian berdasarkan surat Kepala Kantor Pembinaan PMUP nomor surat 203/C.2/III/73 tanggal 2 Mei 1973 tercatat sebagai SMP swasta dengan nama SMP Gunungpati, dan surat nomor 243/C.2/3/74 tanggal 2 Mei 1974 perihal surat tanda tercatat sebagai SMP swasta pada point 2 menyatakan: (1) Nama Sekolah : SMP Daerah Gunungpati (2) Tempat : Gunungpati Ungaran (3) Dibawah Asuhan : Yayasan Pemerintah Daerah Telah tercatat sebagai SMP Swasta dalam daerah Propinsi Jawa Tengah dengan Nomor : IC/15/1974. Adapun sarana yang ada terdiri tujuh ruang kelas, satu ruang tata usaha, satu ruang kepala sekolah, satu ruang gudang dan tiga kamar mandi dengan dua belas orang guru dan tiga orang tata usaha.

Berdasarkan rapat kerja Kepala Sekolah dan Ketua Panitia SMP/SMA persiapan Negeri se Eks Karisidenan Wilayah Departemen P dan K Propinsi Jawa Tengah tanggal 25 Juni 1977 di SMP Negeri 7 Salatiga, panitia SMP Pemerintah Daerah Gunungpati mengajukan permohonan penegerian SMP tersebut, sekaligus 
merupakan pengulangan permohonan surat nomor 01/Papen/SMP/IX/74 tanggal 2 September 1974. Harapan panitia penegerian dapat disahkan karena SMP Pemerintah daerah gunungpati telah diakui sebagai SMP Swasta oleh Kabin PMUP nomor 203/C.2/III/73 tanggal 2 Mei 1973 dan nomor 243/C.2/3/74 tanggal 2 Mei 1974, telah dua kali meluluskan anak didik, mengingat kecamatan Gunungpati sejak tanggal 19 Mei 1976 masuk wilayah kodya Semarang belum memiliki SLTP Negeri, juga memperhatikan anemo masyarakat Gunugpati terhadap adanya SLTP Negeri.

Akhirnya, terbitlah SK Menteri P \& K RI tanggal 15 September 1978 No 0299/O/1978 SMP Pemerintah Daerah Gunungpati menjadi SMP Negeri satu Gunungpati terhitung mulai tanggal 1 April 1978. Menjadi SMP Negeri 22 Semarang sejak 4 Oktober 1984 berdasakan SK Menteri P\& K Nomor 0437/O/1984. Adapun Kepala Sekolah yang pernah memimpin SMP Negeri 22 Semarang sebagai berikut : Sudarmi dari 1 Juni 1976 s. d. 30 Mei 1979, Drs. Dirman Karsimin dari 31 Mei 1979 s. d. 26 Februari 1983, Bedjo Adi Siswanto, B.S.c dari 27 Februari 1983 s. d. 26 September 1990, Sri Retnaningsih dari 27 September 1990 s. d. 31 Maret 1993, Drs. Kardi dan 1 Juni 1993 s. d. 13 Juli 1998, Dra. Sri Purwatini dari 14 Juli 1998 s. d. 27 April 2004, Drs. Al Bekti Wisnu Tomo dari 28 April 2004 s. d 15 November 2005, Drs. Puyadi M.Pd dari 16 November 2005 s. d. 12 November 2009, Dra. H. Ida N Candra M.Pd dari 13 November 2009 s. d. 24 November 2012, Drs. Catonggo Sulistiyono S.Kom dari 25 November 2012 s. d. sekarang. 


\subsubsection{Prestasi Siswa}

Prestasi siswa merupakan capaian keberhasilan siswa dalam berbagai bidang baik akademik maupun non akademik. Prestasi yang telah diraih oleh siswa dan siswi SMPN 22 Semarang terdiri dari finalis Karya Ilmiah Remaja Tingkat Kota, juara III KIR tingkat Kota, juara Harapan III Putra Siswa Teladan Tingkat Kota, juara I Vocabulary Tk Kota Semarang, juara I Treasure Hunt Tk Kota Semarang, juara II Grammer Tingkat Kota Semarang, juara III General Knoledge Kota Semarang, juara III Writing Tingkat Kota Semarang dan juara I Lomba Cipta Puisi Tingkat Kota Semarang, juara I MTQ Putri, juara 1 lari $60 \mathrm{~m}$ $\mathrm{Pa}$ O2SN Tk. Kota, juara I lari $60 \mathrm{~m} \mathrm{~Pa} \mathrm{O2SN} \mathrm{Tk.} \mathrm{Provinsi,} \mathrm{juara} \mathrm{II} \mathrm{Lempar}$ Lembing Pi. O2SN Tk. Kota, juara III Lopat Jauh Pi. O2SN Tk. Kota, juara I Lompat Jauh Pi. POPDA Tk. Kota, juara Umum Pa. Lomba Pramuka Tk. Provinsi, juara I PBB Pa. Tk. Provinsi, juara II Futsal Tk. Kota Semarang, juara II dan Juara III Lomba Akting Kota Semarang dan masih banyak lagi prestasiprestasi yang lainya

\subsubsection{Kegiatan Ekstrakurikuler}

Kegiatan ekstrakurikuler merupakan kegiatan di luar mata pelajaran yang dilakukan peserta didik di kelas maupun di luar kelas, umumnya di luar jam pelajaran. Kegiatan ini ditujukan agar siswa dapat mengembangkan kepribadian, bakat, dan kemampuanya di berbagai bidang di luar bidang akademik. Adapun kegiatan ekstrakurikuler di SMPN 22 Semarang terdiri dari berbagai kegiatan baik itu di bidang seni, olahraga maupun pengembangan kepribadian. Kegiatan ekstrakurikuler di SMPN 22 Semarang diantaranya yaitu BTA (Baca Tulis Al- 
Qur'an, pramuka, komputer, PMR, KIR, conversation, english club, matematic club, paskibra, mading, karawitan, seni musik, seni tari, sepak bola, bola voli, bulu tangkis, dan pencak silat.

\subsubsection{Sarana dan Prasarana}

Sarana dan prasarana merupakan alat yang dibutuhkan guna menunjang keefektifan proses belajar mengajar. Sarana dan prasarana yang tersedia di SMPN 22 Semarang cukup lengkap dan memadai untuk kegiatan pendidikan. Sarana dan prasarana yang tersedia terdiri dari ruang perpustakaan, ruang laboraturium IPA, ruang pimpinan, ruang komputer, ruang guru, ruang tata usaha, tempat beribadah, ruang konseling, ruang UKS, ruang organisasi kesiswaan, jamban, gudang, ruang sirkulasi, dan tempat bermain/berolahraga.

Adapun sarana dan prasarana pendukung yaitu terdiri dari greenhouse, kebun sekolah, ruang karawitan, ruang seni musik, ruang pramuka, ruang penyimpanan alat olahraga, koperasi sekolah, dapur sekolah, kamar mandi/WC guru, kamar mandi/WC siswa, gedung pertemuan aula, dan tempat parkir satu dan dua. Berbagai fasilitas juga disediakan oleh SMPN 22 Semarang seperti empat puluh empat unit komputer yang terhubung dengan jaringan Local Arean Network (LAN), tekhnologi jaringan nirkabel berupa HOT SPOT area dengan acces point sebanyak empat titik yang memungkinkan warga sekolah untuk mengakses internet di seluruh ruang kelas dan halaman sekolah, sistim aplikasi sekolah terintegrasi dengan internet, laptop, LCD projector yang terpasang di ruang kelas dan ruang laboraturium, mesin penggandaan, mesin foto copy dan lain-lain. 


\subsubsection{Visi dan Misi}

Visi dan misi sekolah merupakan sebuah rumusan cita-cita yang ingin dicapai sekolah melalui proses pembelajaran. Dengan kata lain, fungsi visi dan misi menjadi sebuah arah dalam proses pembelajaran untuk mewujudkan cita-cita yang diharapkan. Uraian visi dan misi SMPN 22 Semarang tahun ajaran 2016/2017 yaitu sebagai berikut. (a) Visi : Terwujudnya insan bertakwa, berbudi pekerti luhur dan berprestasi, dan bersahabat dengan lingkungan. (b) Misi : (1) Meningkatkan keimanan dan ketakwaan terhadap Tuhan Yang Maha Esa. (2) Meningkatkan perilaku yang baik sesuai dengan norma agama dan budaya bangsa. (3) Mengembangkan isi kurikulum dan pembelajaran dengan pendekatan CTL. (4) Meningkatkan mutu pembelajaran berbasis IT. (5) Mengembangkan kompetensi guru dan tenaga kependidikan. (6) Meningkatkan dan mengembangkan fasilitas dan sarana pendidikan. (7) Meningkatkan hasil penilaian dan kualitas lulusan yang memiliki daya saing. (8) Meningkatkan mutu kelembagaan dan manajemen sekolah. (9) Meningkatkan suasana lingkungan sekolah yang kondusif. (10) Meningkatkan kepedulian terhadap lingkungan sekolah yang bersih, sehat, dan asri.

\subsubsection{Tenaga Pengajar SMPN 22 Semarang}

SMPN 22 Semarang memiliki 35 orang tenaga pengajar, dua orang wakil kepala sekolah dan seorang kepala sekolah. Tiap-tiap guru mengajarkan mata pelajaran sesuai dengan ijazahnya masing-masing termasuk guru Seni Budaya. Pelajaran Seni Budaya di SMPN 22 Semarang diampu oleh dua tenaga pendidik, yaitu bapak Kasih yang mengajarkan materi Seni Tari, Seni Rupa dan Seni Musik 
dan ibu Siti Maskurotun yang mengajarkan materi Seni Musik. Guru pengajar di SMPN 22 Semarang mmiliki latar belakang pendidikan variatif yaitu tamat Strata dua (S2), Strata satu (S1), Diploma I (D1), dan Diploma II (D2). Untuk mengetahui keadaan pendidik dan tenaga kependidikan dan tingkat lulusan pendidikanya dapat dilihat pada tabel berikut.

Tabel 4.1 Kualifikasi Pendidikan, Status, Jenis Kelamin, dan Jumlah Guru

\begin{tabular}{|c|l|c|c|c|c|c|}
\hline \multirow{2}{*}{ No } & \multirow{2}{*}{ Tingkat Pendidikan } & \multicolumn{3}{|c|}{ Jumlah dan Status Guru } & \multirow{2}{*}{} \\
\cline { 3 - 6 } & & \multicolumn{2}{|c|}{ GT/PNS } & \multicolumn{2}{|c|}{$\begin{array}{c}\text { GTT/Guru } \\
\text { Bantu }\end{array}$} & \\
\cline { 3 - 6 } & & L & P & L & P & \\
\hline 1. & S3/S2 & & & - & - & 3 \\
\hline 2. & S1 & & & - & - & 28 \\
\hline 3. & D-4 & - & - & - & - & - \\
\hline 4. & D3/Sarmud & & & - & - & 2 \\
\hline 5. & D2 & - & - & - & - & - \\
\hline 6. & D1 & & & - & - & 2 \\
\hline 7. & $\leq$ SMA/sederajat & - & - & - & - & - \\
\hline \multicolumn{2}{|c|}{ Jumlah } & & & - & - & 35 \\
\hline
\end{tabular}

\subsubsection{Kepala Sekolah}

Tugas kepala sekolah yaitu memajukan sekolah. Seperti yang dikatakan oleh Muhadjir (Mentri Pendidikan dan Kebudayaan) yang mengatakan bahwa kepala sekolah merupakan manajer sebuah sekolahan. Setiap sekolah di Indonesia adalah pusat manajemen pendidikan, dan tugas mengubah menejemen itu ada pada kepala sekolah sebagai menejer sekolah. Untuk itu, untuk memajukan pendidikan di Indonesia, kepala sekolah memegang penuh kendali maju atau tidaknya sekolah, sehingga apabila menjadi kepala sekolah penting membuat ide kreatif untuk memajukan sekolah. Kepala Sekolah di SMPN 22 Semarang dibantu oleh wakil kepala sekolah yang terdiri dari wakil kepala sekolah I dan wakil 
kepala sekolah II dalam melaksanakan tugasnya. Berikut ini tabel data mengenai pendidikan, usia dan masa kerja kepala sekolah dan wakil-wakil kepala sekolah.Dalam menjalankan tugasnya sebagai kepala sekolah, kepala sekolah dapat menggantikan guru yang tidak bisa mengajar jika ada guru yang berhalangan untuk melaksanakan tugas mengajarnya.

Tabel 4.2 Data Kepala Sekolah dan Wakil Kepala Sekolah

\begin{tabular}{|c|c|c|c|c|c|c|c|c|}
\hline \multirow{2}{*}{ No } & \multirow{2}{*}{ Jabatan } & \multicolumn{2}{|c|}{ Nama } & \multicolumn{2}{|c|}{$\begin{array}{c}\text { Jenis } \\
\text { Kelamin }\end{array}$} & \multirow{2}{*}{$\begin{array}{c}\text { Usia } \\
(\mathrm{TH})\end{array}$} & $\begin{array}{c}\text { Pendidikan } \\
\text { Akhir }\end{array}$ & \multicolumn{2}{|c|}{$\begin{array}{c}\text { Masa } \\
\text { Kerja }\end{array}$} \\
1. SH & BL \\
\hline 1. & Kepala Sekolah & $\begin{array}{l}\text { Drs. Sawukir } \\
\text { M.Pd }\end{array}$ & L & - & 51 & S2 & 23 & 06 \\
\hline 2. & $\begin{array}{l}\text { Wakil Kepala } \\
\text { Sekolah I }\end{array}$ & $\begin{array}{l}\text { Joko Winarno, } \\
\text { M.Pd }\end{array}$ & L & - & 49 & S2 & 49 & 03 \\
\hline 3. & $\begin{array}{l}\text { Wakil Kepala } \\
\text { Sekolah II }\end{array}$ & $\begin{array}{l}\text { Widharningsih } \\
\text { S.Pd }\end{array}$ & - & P & 47 & S1 & 11 & 02 \\
\hline
\end{tabular}

\subsubsection{Guru}

Guru merupakan orang yang mempunyai tanggung jawab mengajar dan mendidik siswa di sekolah. Guru di SMPN 22 Semarang menempuh jenjang pendidikan yang terdiri dari D1, D3, S1, dan S2. Berikut ini disajikan tabel jumlah guru dengan tugas mengajar sesuai dengan latar belakang pendidikan (keahlian) dari berbagai macam jenjang pendidikan.

Tabel 4.3 Jumlah Guru Sesuai dengan Latar Belakang Pendidikan

\begin{tabular}{|c|c|c|c|c|c|c|}
\hline No & Guru & D1 & D3 & S1 & S2 & Jumlah \\
\hline 1 & IPA & 1 & - & 3 & 1 & 5 \\
\hline 2 & Matematika & - & - & 3 & - & 3 \\
\hline 3 & B. Indonesia & - & 1 & 3 & - & 4 \\
\hline 4 & B. Inggris & - & - & 5 & - & 5 \\
\hline 5 & Pend. Agama & - & - & 2 & 1 & 3 \\
\hline 6 & IPS & - & - & 4 & - & 4 \\
\hline 7 & Penjasorkes & 1 & - & - & 1 & 2 \\
\hline 8 & Seni Budaya & - & - & 2 & - & 2 \\
\hline 9 & PKN & - & - & 2 & - & 2 \\
\hline
\end{tabular}




\begin{tabular}{|c|c|c|c|c|c|c|}
\hline 10 & TIK & - & - & 2 & - & 2 \\
\hline 11 & B. Jawa & - & 1 & 2 & - & 3 \\
\hline & Jumlah & 2 & 2 & 28 & 3 & 35 \\
\hline
\end{tabular}

\subsubsection{Struktur Organisasi Sekolah}

Dalam pelaksanaan pembelajaran di SMP Negeri 22 Semarang kepala sekolah dibantu oleh wakil kepala sekolah, ketua-ketua urusan, staf pimpinan, guru, tata usaha, dan karyawan, serta yang tidak kalah penting adalah komite sekolah yang turut mengawasi arah kebijakan pengembangan sekolah yang tersusun dalam tata organisasi sekolah. Untuk memperjelas struktur organisasi di SMP Negeri 22 Semarang akan disajikan bagan dalam gambar 4.1 Berikut:

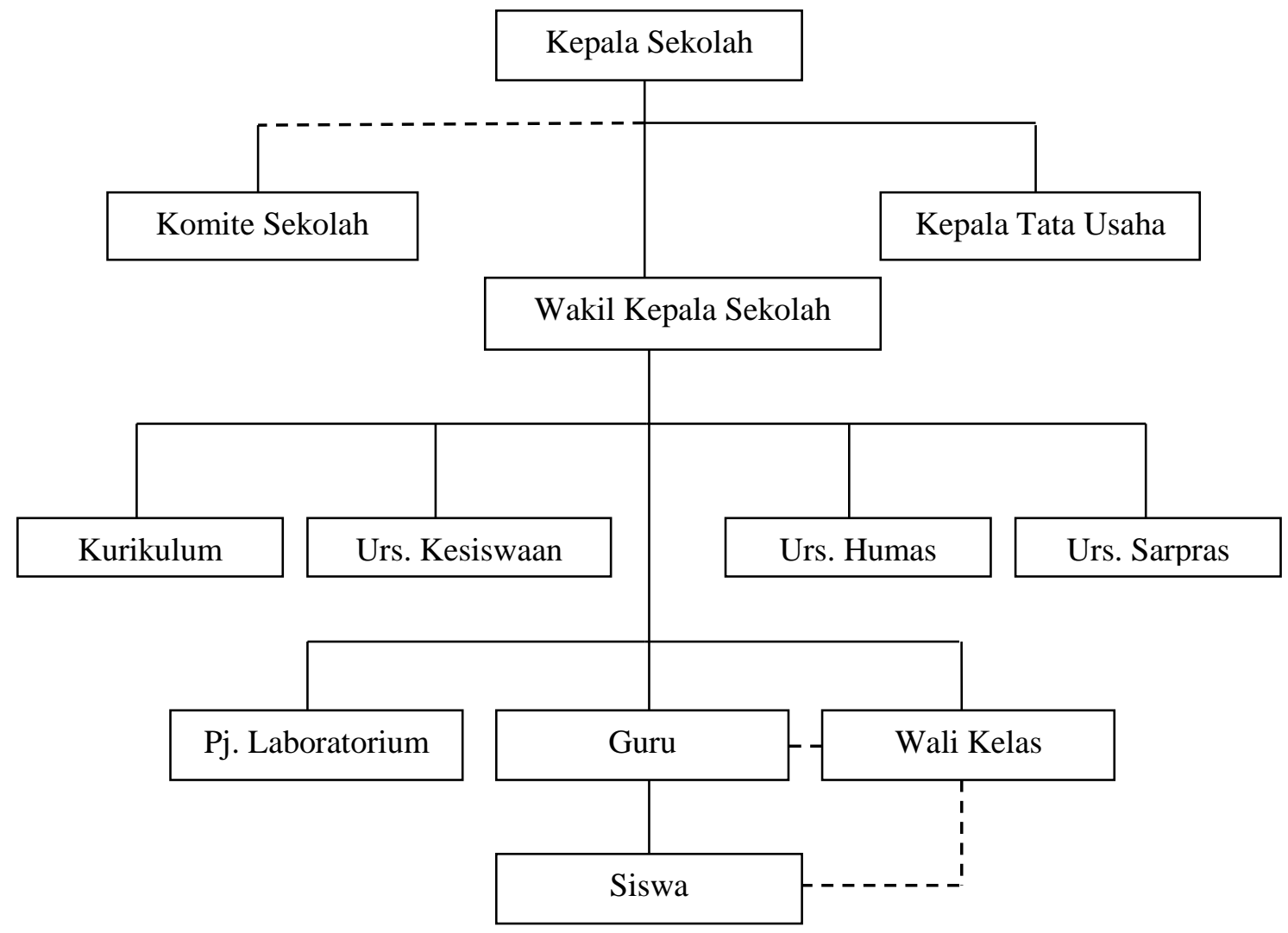


Keterangan :

Garis komando

Garis koordinasi

Bagan 4.1 Struktur Organisasi SMPN 22 Semarang

Sumber : Data Struktur Organisasi SMP Negeri 22 Semarang

\subsubsection{Siswa SMPN 22 Semarang}

Pada tahun 2016/2017 jumlah siswa SMP Negeri 22 Semarang tercatat sebanyak 780 siswa dengan pembagian dalam kelas VII dibagi menjadi 8 ruang kelas, kelas VIII dibagi menjadi 8 ruang kelas, dan kelas IX yang juga dibagi menjadi 8 ruang kelas. Siswa terbagi atas kelas VII berjumlah 283 anak, kelas VIII berjumlah 246 anak, dan kelas IX berjumlah 251 anak. Secara keseluruhan jumlah siswa di SMP Negeri 22 Semarang terdiri atas 343 siswa laki-laki dan 437 siswa perempuan. Adapun rincian selengkapnya sebagai berikut :

Tabel 4.4 Jumlah Siswa SMPN 22 Semarang

\begin{tabular}{|c|c|c|c|}
\hline Kelas & Laki-laki & Perempuan & Jumlah \\
\hline VII A & 12 & 24 & 36 \\
\hline VII B & 18 & 18 & 36 \\
\hline VII C & 18 & 18 & 36 \\
\hline VII D & 15 & 20 & 35 \\
\hline VII E & 16 & 20 & 36 \\
\hline VII F & 16 & 20 & 36 \\
\hline VII G & 15 & 20 & 35 \\
\hline VII H & 16 & 17 & 33 \\
\hline VIII A & 8 & 24 & 32 \\
\hline VIII B & 11 & 20 & 31 \\
\hline VIII C & 11 & 20 & 31 \\
\hline VIII D & 13 & 18 & 31 \\
\hline VIII E & 14 & 18 & 32 \\
\hline VIII F & 14 & 17 & 31 \\
\hline VIII G & 14 & 16 & 30 \\
\hline VIII H & 12 & 16 & 28 \\
\hline IX A & 10 & 22 & 32 \\
\hline IX B & 16 & 16 & 32 \\
\hline IX C & 16 & 16 & 32 \\
\hline
\end{tabular}




\begin{tabular}{|c|c|c|c|}
\hline IX D & 16 & 16 & 32 \\
\hline IX E & 16 & 16 & 32 \\
\hline IX F & 14 & 16 & 30 \\
\hline IX G & 16 & 14 & 30 \\
\hline IX H & 16 & 15 & 31 \\
\hline Jumlah & $\mathbf{3 4 3}$ & $\mathbf{4 3 7}$ & $\mathbf{7 8 0}$ \\
\hline
\end{tabular}

Sumber : Daftar Nama Siswa SMP Negeri 22 Semarang 2016/2017

\subsubsection{Tenaga Administrasi dan Tenaga Pendukung SMPN 22 Semarang}

Tenaga administrasi dan tenaga pendukung di SMP Negeri 22 Semarang pada tahun 2016/2017 terdiri dari sepuluh bagian. Masing-masing bagian terdiri dari satu pegawai yang mempunyai latar belakang pendidikan yang berbeda. Agar lebih rinci data tenaga pendukung SMPN 22 Semarang disajikan dalam tabel berikut ini.

Tabel 4.5 Tenaga Administrasi dan Tenaga Pendukung SMPN 22 Semarang

\begin{tabular}{|c|l|c|c|c|c|c|c|c|c|c|c|c|}
\hline \multirow{2}{*}{ No } & \multirow{2}{*}{$\begin{array}{l}\text { Tenaga } \\
\text { Pendukung }\end{array}$} & SMP & SMA & D1 & D2 & D3 & S1 & \multicolumn{2}{|c|}{ PNS } & \multicolumn{2}{|c|}{ Honorer } & \multirow{2}{*}{ Jumlah } \\
\cline { 2 - 11 } 1. & $\begin{array}{l}\text { Koordinator } \\
\text { Administrasi }\end{array}$ & - & - & 1 & - & - & - & - & P & - & - & 1 \\
\hline 2. & Kebersihan & 1 & - & - & - & - & - & L & - & - & - & 1 \\
\hline 3. & Kepegawaian & 1 & - & - & - & - & - & L & - & - & - & 1 \\
\hline 4. & Kesiswaan & - & - & - & 1 & - & - & - & & - & P & 1 \\
\hline 5. & $\begin{array}{l}\text { Kebersihan } \\
\text { dan pemb. } \\
\text { Air minum }\end{array}$ & - & 1 & - & - & - & - & - & - & - & P & 1 \\
\hline 6. & Kebersihan & - & 1 & - & - & - & - & - & - & L & - & 1 \\
\hline 7. & $\begin{array}{l}\text { Persuratan } \\
\text { dan satpam }\end{array}$ & - & 1 & - & - & - & - & - & - & L & - & 1 \\
\hline 8. & Kebersihan & - & 1 & - & - & - & - & - & - & L & - & 1 \\
\hline 9. & $\begin{array}{l}\text { Penjaga } \\
\text { malam }\end{array}$ & - & 1 & - & - & - & - & - & - & L & - & 1 \\
\hline 10. & $\begin{array}{l}\text { Penjaga } \\
\text { malam 2 }\end{array}$ & - & 1 & - & - & - & - & - & - & L & - & 1 \\
\hline
\end{tabular}




\subsection{Implementasi Pembelajaran Ansambel Musik di SMPN 22 Semarang}

Implementasi dalam pembelajaran ansambel musik di SMPN 22 Semarang meliputi pembelajaran karawitan sebagai alternatif dalam melaksanakan kompetensi menampilkan lagu etnik nusantara dalam bentuk ansambel musik dan kegiatan perencanaan, pelaksanaan, dan evaluasi pembelajaran ansambel musik di SMPN 22 Seamrang.

\subsubsection{Pembelajaran Karawitan sebagai Alternatif dalam Melaksanakan Kompetensi Menampilkan Lagu Etnik Nusantara dalam Bentuk Ansambel Musik}

Sebuah pembelajaran memiliki sifat yang sangat kompleks karena melibatkan aspek pedagogis, psikologis, dan didaktis (Mulyasa dalam Fitriyati, 2016:18). Pedagogis bermakna bahwa guru menjadi pendamping siswa dalam proses belajar di lingkungan pendidikan yang terprogram. Psikologis bermakna bahwa siswa memiliki kemampuan belajar dan sifat serta kepribadian yang bermacam-macam sehingga guru pun harus memahami siswanya tidak sebatas luarnya saja. Sedangkan didaktis bermakna bahwa seorang guru harus memilih dan menentukan jenis pembelajaran yang akan diterapkan dengan menyesuikan dengan kompetensi yang akan diajarkan (Fitriyati, 2016:18).

Di dalam kurikulum tingkat satuan pendidikan, salah satu standar kompetensi yang harus dicapai oleh siswa adalah siswa dapat mengekspresikan diri melalui karya seni musik. Adapun salah satu kompetensi dasarnya adalah menyajikan karya seni musik tradisional Nusantara secara perseorangan dan berkelompok di kelas atau di sekolah. Melalui kompetensi dasar ini, guru diharuskan untuk mengajar siswa agar siswa mampu menyajikan karya seni musik 
tradisional baik secara perseorangan maupun kelompok. Tahap yang harus dilakukan guru yaitu melakukan perencanaan pembelajaran terlebih dahulu dengan menyiapkan rencana pelaksanaan pembelajaran. Di dalam kurikulum tingkat satuan pendidikan, guru atau sekolah diberikan hak untuk mengembangkan pembelajaranya sesuai dengan kemampuan guru, karakteristik siswa, dan fasilitas yang tersedia.

Berdasarkan pengamatan peneliti, di SMPN 22 Semarangterdapatberbagai sarana dan prasarana yang disediakan oleh sekolah untuk kepentingan pembelajaran salah satunya yaitu ruang gamelan jawa. Berdasarkan wawancara dengan guru seni musik kelas VIII, kepala sekolah SMPN 22 Semarang memang menyukai kesenian jawa terutama gamelan jawa. Hal ini terbukti dari setiap event yang diadakan SMPN 22 Semarangselalu melibatkan gamelan jawa. Seperti yang pernah dilakukan di SMPN 22 Semarang pada tahun 2016 dalam rangka memperingati hari pahlawan nasional, SMPN 22 Semarang mengadakan lomba memainkan gamelan jawa khusus untuk siswa di SMPN 22 Semarang yang mewakilkan perwakilanya setiap kelas. Acara ini diikuti oleh perwakilan setiap kelas dan disaksikan oleh guru-guru, siswa, dan semua karyawan SMPN 22 Semarang. Acara ini sangat meriah sehingga ada salah satu surat kabar kota semarang yang meliput kegiatan tersebut.Sehingga ini semakin memperkuat semangat guru maupun sekolah dalam melestarikan gamelan jawa di lingkungan sekolah.

Adapun di SMPN 22 Semarang guru seni musik kelas VIII SMPN 22 Semarang adalah seorang yang mempunyai kemampuan yang mumpuni dalam hal 
bermain gamelan jawa. Beliau sangat mahir memainkan gamelan jawa. Nada-nada yang terdapat pada alat musik gamelan sudah menyatu dengan beliau. Hal ini sangat logis, sebab melihat latar belakang guru seni musik kelas VIII SMPN 22 Semarang adalah lulusan seni tari pada jenjang pendidikan D2 dan lulusan seni musik S1. Sehingga gamelan yang menjadi iringan tari sudah tidak asing lagi ditelinga beliau.

Sedangkan dari aspek siswa, berdasarkan hasil tanggapan siswa terhadap angket faktor-faktor yang mempengaruhi hasil belajar ansambel musik, siswa kelas VIII C SMPN 22 Semarang menanggapinya dengan positif. Artinya kedisiplinan di dalam sekolah merupakan hal yang penting bagi mereka. Berdasarkan kenyataan tersebut, sudah dapat diketahui bahwa disiplin siswa dalam belajar juga tinggi. Untuk itu, belajar bagi mereka merupakan suatu aktivitas yang harus dilaksanakan dengan serius.

Berdasarkan alasan tersebutlah ansambel gamelan jawa diajarkan di SMPN 22 Semarang. Semua aspek sangat mendukung baik sekolah, guru, maupun siswa untuk adanya pembelajaran ansambel gamelan jawa di SMPN 22 Semarang.

\subsubsection{Kegiatan Perencanaan, Pelaksanaan dan Evaluasi Pembelajaran Ansambel Musik di SMPN 22 Semarang}

\subsubsection{Perencanaan}

Kurikulum Tingkat Satuan Pendidikan (KTSP) adalah kurikulum operasional yang disusun oleh dan dilaksanakan di masing-masing satuan pendidikan. KTSP terdiri dari tujuan pendidikan tingkat satuan pendidikan, struktur dan muatan kurikulum tingkat satuan pendidikan, dan silabus. Silabus 
adalah rencana pembelajaran pada suatu kelompok mata pelajaran tema tertentu yang mencangkup standar kompetensi, kompetensi dasar, materi pokok pembelajaran, kegiatan pembelajaran, indikator pencapaian kompetensi untuk penilaian, penilaian, alokasi waktu, dan sumber belajar. Rencana Pelaksanaan Pembelajaran adalah rencana yang menggambarkan prosedur dan pengorganisasian pembelajaran untuk mencapai suatu kompetensi dasar yang ditetapkan dan dijabarkan dalam silabus.

Di dalam Silabus, Standar Kompetensi yang yang harus dicapai siswa yaitu siswa dapat mengekspresikan diri melalui karya seni musik. Melalui Kompetensi Dasar menyajikan karya seni musik tradisional Nusantara secara perseorangan dan berkelompok di kelas atau di sekolah, materi yang diberikan berupa penyajian musik. Kegiatan pembelajaran yang dilakukan yaitu berlatih memainkan hasil aransemen dan menyajikan musik hasil aransemen baik perorangan maupun kelompok dengan alokasi waktu empat jam pelajaran. Adapun indikator dari pencapaian kompetensi yaitu siswa mampu menyajikan karya musik secara perorangan dan kelompok di kelas maupun di sekolah. Teknik penilaian berupa tes praktik kinerja dan bentuk instrumen penilaian berupa tes uji petik kerja. Sumber belajar yang digunakan berupa partitur lagu-lagu nusantara, alat-alat musik yang digunakan, dan buku teks.

Di dalam Rencana Pelaksanaan Pembelajaran (RPP), Standar kompetensiyang harus dicapai yaitu siswa dapat mengekspresikan diri melalui karya seni musik. Melalui kompetensi dasar menyajikan karya seni musik etnik nusantara untuk disajikan secara perorangan dan kelompok di kelas atau di 
sekolah,tujuan yang ingin dicapai pada akhir pembelajaran adalah membentuk susunan panitia pagelaran, menyajikan lagu etnik nusantara sesuai dengan pilihan kelompok dan berlatih memainkan lagu nusantara dengan alat musik melodis secara kelompok. Karakter siswa yang diharapkan yaitu disiplin, tekun, tanggung jawab, ketelitian, kerja sama, percaya diri, dan kecintaan. Materi pembelajaran yang akan disampaikan adalah kreasi musik nusantara dan pergelaran kelas dengan alokasi waktu 4 x 40 menit ( 2 x pertemuan). Metode pembelajaran yang digunakan yaitu metode pendekatan CTL dan life skill.

Adapun langkah-langkah pembelajaran pada pertemuan pertama dan kedua meliputi kegiatan pendahuluan, kegiatan inti, dan kegiatan penutup. Pada kegiatan pendahuluan guru melakukan tanya jawab berbagai hal terkait dengan wawasan siswa mengenai materi yang akan disajikan. Pada kegiatan inti kegiatankegiatan yang dilaksanakan adalah eksplorasi, elaborasi, dan konfirmasi. Pada kegiatan penutup guru menanyakan kesulitan siswa selama PBM dan menugaskan untuk berlatih memainkan hasil aransemen secara kelompok. Untuk alat dan sumber belajar yang digunakan selama pembelajaran adalah buku "Seni Budaya", Cassette/DVD/guru, recorder sopran, pianika, dan gitar akustik.

Penilaian dilaksanakan selama proses dan sesudah pembelajaran. Indikator pencapaian kompetensi yaitu siswa mampu membuat perencanaan pementasan di dalam kelas dengan uraian tugas yang tepat, dan memainkan hasil aransemen. Penilaian terkait dengan teknik, bentuk instrumen, dan contoh instrumen. Dengan format penilaian meliputi aspek-aspek kepanitiaan, kekompakan kelompok, kreatifitas aransemen, dan kedisiplinan dalam berlatih. 


\subsubsection{Pelaksanaan}

Tahap pelaksanaan dilaksanakan selama tiga pertemuan dengan waktu masing-masing pertemuan 2 x 40 menit. Pada setiap pertemuan guru menyampaikan materi dengan tahapan pembukaan, inti, dan penutup.Padakegiatan pendahuluan guru melakukan tanya jawab berbagai hal terkait dengan wawasan siswa mengenai materi yang akan disajikan. Pada kegiatan inti diawali dengan eksplorasi. Dalam kegiatan eksplorasi, guru membuat perencanaan pagelaran, menyanyikan lagu etnik nusantara sesuai pilihan dengan kelompoknya, dan memfasilitasi peserta didik melakukan percobaan di studio, atau lapangan.

Tahapan kedua adalah elaborasi. Dalam kegiatan elaborasi, guru melatih secara kelompok lagu pilihan dengan alat musik melodis, guru menuliskan hasil aransemen sederhana lagu pilihan dalam kelompok, guru memfasilitasi peserta didik melakukan pameran, turnamen, festival, serta produk yang dihasilkan. Tahapan yang ketiga adalah konfirmasi. Dalam kegiatan konfirmasi, guru memberikan umpan balik positif dan penguatan dalam bentuk lisan, tulisan, isyarat, maupun terhadap keberhasilan peserta didik. Guru memberikan konfirmasi terhadap hasil eksplorasi dan elaborasi peserta didik melalui berbagai sumber. Guru memfasiltasi peserta didik melakukan refleksi untuk memperoleh pengalaman belajar yang telah dilakukan. Guru memfasilitasi peserta didik untuk memperoleh pengalaman yang bermakna dalam mencapai kompetensi dasar yang mencangkup: a) guru berfungsi sebagai narasumber dan fasilitator dalam menjawab pertanyaan peserta didik yang menghadapi kesulitan, dengan 
menggunakan bahasa yang baku dan benar; b) membantu menyelesaikan masalah; c) memberi acuan agar peserta didik dapat melakukan pengecekan hasil eksplorasi; d) memberi informasi untuk bereksplorasi lebih jauh; e) memberi motivasi kepada peserta didik yang kurang atau belum berpartisipasi aktif.

Pada kegiatan penutup guru menanyakan kesulitan siswa selama proses belajar mengajar dan guru juga menugaskan untuk berlatih memainkan hasil aransemen secara kelompok. Alat dan sumber belajar yang digunakan untuk proses belajar mengajar adalah buku Seni Budaya, guru, seperangkat gamelan jawa yang meliputi bonang barung, bonang penerus, saron, demung, kethuk, kenong, kendhang, gong.

Berdasarkan analisis peneliti, ada beberapa kegiatan yang tercantum di RPP akan tetapi pada pelaksanaanya tidak dilaksanakan sebagaimana mestinya. Contoh pada kegiatan inti yaitu pada kegiatan eksplorasi, perencanaan pergelaran tidak dilaksanakan dan setiap kelompok tidak menentukan lagunya masingmasing. Pada kegiatan elaborasi, setiap kelompok tidak menuliskan aransemen sederhana lagu pilihan, serta tidak ada pelaksanaan pameran, turnamen, festival, serta produk yang dihasilkan dari kegiatan pembelajaran tersebut. Alokasi jam pelajaran yang ada pada perencanaan pembelajaran tidak sesuai dengan pelaksanaan pembelajaran.

\subsection{Proses Pelaksanaan Pembelajaran Ansambel Musik di Kelas VIII C SMPN 22 Semarang}

Pertemuan pertama dalam tahap pendahuluan, guru mengkodisikan siswa agar siap mengikuti pembelajaran. Guru melakukan apersepsi dengan melakukan tanya jawab tentang pengalaman siswa terkait ansambel meliputi pengertian dan 
unsur-unsur musik. Ada beberapa siswa yang aktif menjawab sesuai dengan yang mereka tahu, siswa yang lainya ada yang diam dan ada yang mencoba mencari tahu lewat buku paket. Setelah itu, siswa diberi motivasi serta penjelasan oleh guru mengenai tujuan, manfaat, cakupan materi pembelajaran, dan langkahlangkah yang akan dilakukan dalam pembelajaran keterampilan bermain ansambel.

Pada tahap inti,siswa diberi penjelasan tentang teori mengenai ansambel gamelan jawa. Kemudian guru menuliskan dan menjelaskan notasi lagu suwe ora jamu gamelan jawa di papan tulis. Adapun deskripsi dari notasi lagu suwe ora jamu gamelan jawa adalah sebagai berikut:

Notasi lagu suwe ora jamu menggunakan pelog 6 , alat musik yang menjadi BK (buko) adalah bonang barung dan kendang. Dengan notasi BK untuk bonang barung yaitu $-3-5-6-5-3-2-6 / 6-6 / 6$, di barengi dengan notasi kendang BK $t \mathrm{t} p \mathrm{~b} p \mathrm{p} p$. Notasi t berbunyi tak, $\mathrm{p}$ berbunyi pung, sedangkan $\mathrm{b}$ berbunyi bum. Setelah notasi $6 / 6$ dan $\mathrm{p}$ langsung diikuti oleh gong dengan simbol lingkaran. Dan setelah gong dibunyikan barulah diikuti dengan alat musik yang lain seperti kethuk dengan simbol + , kenong dengan simbol $\mathrm{N}$, dan kempul dengan simbol P. Dengan notasi lagu $++\mathrm{N}+\mathrm{P}+\mathrm{N}+\mathrm{P}+\mathrm{N}+\mathrm{P}+\mathrm{N}$.

Guru mengarahkan siswa untuk berkelompok tujuh sampai delapan orang sesuai urut absen untuk dilatih ansambel secara berkelompok. Mula-mula kelas sempat gaduh saat siswa mulai berkelompok dengan temanya. Namun berlahanlahan suasana gaduh kembali normal setelah masing-masing siswa telah berkelompok. 
Setelah siswa berkelompok, siswa ditempatkan pada masing-masing alat musik yang dipilih oleh siswa untuk dimainkan. Siswa diarahkan untuk memahami masing-masing alat musik yang dimainkan dengan diberi contoh oleh guru. Ketika guru memberi contoh atau arahan, tidak jarang ada siswa yang bertanya terkait arahan yang diberikan oleh guru. Guru pun mengulangi arahan yang dianggap kurang jelas.

Setelah siswa selesai diberi arahan, siswa bersama masing-masing kelompoknya dibimbing oleh guru untuk berlatih memainkan alat musik gamelan secara berkelompok. Pada tahap ini, ada beberapa siswa yang terlihat kurang sungguh-sungguh dengan menyandarkan badanya ke tembok tetapi latihan tetap berjalan secara bergantian per kelompok. Guru memberikan apresiasi kepada siswa yang memainkan gamelan jawa dengan baik dan benar. Guru mengajari siswa yang masih keliru dalam memainkan gamelan jawa.

Pada tahap penutup, siswa bersama guru menyimpulkan pembelajaran yang telah dilaksanakan dari awal hingga akhir. Siswa bersama guru melaksanakan refleksi kegiatan pelajaran yang telah dilaksanakan sebelumnya. Tidak lupa guru memberikan penguatan terhadap hasil refleksi dari pembelajaran yang telah dilaksanakan. Guru dan siswa bersama-sama menutup pembelajaran.

Pada pertemuan kedua tahap pendahuluan, guru mengkondisikan siswa agar siap mengikuti pembelajaran. Guru mengulas kembali sekaligus bertanya jawab dengan siswa terkait materi yang telah dipelajari sebelumnya mengenai langkah-langkah memainkan ansambel gamelan jawa. Seperti pada pertemuan pertama, siswa di kelas ini ada yang aktif menjawab dan ada yang diam. Guru 
menyampaikan cangkupan materi pembelajaran dan langkah-langkah yang akan dilakukan dalam pembelajaran memainkan ansambel gamelan jawa.

Pada tahap inti, siswa diarahkan untuk menempati alat musik gamelan yang telah dipilih pada pertemuan sebelumnya. Guru mulai melatih siswa per kelompok. Pada tahap ini, beberapa siswa terlihat konsentrasi tetapi ada juga yang merasa kesulitan dalam memainkan ansambel jawa. Dengan sabar guru mengajari dan mengarahkan siswa yang masih kesulitan. Selain itu ada juga siswa yang sering menengok ke kanan kiri karena belum bisa memainkan gamelan dengan tepat. Guru juga mengarahkan siswa tersebut dalam meminkan sebisa guru membantu siswa tersebut. Masing-masing siswa ada yang terlihat serius dalam mengikuti pembelajaran latihan memainkan ansambel dan ada juga yang mengobrol dengan teman-temanya saat menunggu giliran latihan.

Setelah latihan selesai, guru memberikan apresiasi dan memberi motivasi terhadap pembelajaran yang telah dilaksanakan. Siswa bersama guru menyimpulkan pembelajaran yang telah dilakukan. Siswa bersama guru merefleksi kegiatan pembelajaran yang telah dilakukan dan menyampaikan persiapan evaluasi untuk minggu depan. Bersama-sama siswa dan guru menutup pembelajaran.(Suharto, Sumaryanto, \& Ganap, 2017)

Pada pertemuan ketiga tahap pendahuluan, guru mengkondisikan siswa agar siap mengikuti pembelajaran. Guru mengulas kembali sekaligus bertanya jawab dengan siswa terkait materi yang telah dipelajari sebelumnya mengenai langkah-langkah memainkan ansambel gamelan jawa. Seperti pada pertemuan kedua, siswa di kelas ini ada yang aktif menjawab dan ada yang diam. Guru 
menyampaikan langkah-langkah yang akan dilakukan dalam pembelajaran dalam tes memainkan ansambel gamelan jawa.

Pada tahap inti, siswa diarahkan untuk menempati alat musik gamelan yang telah dipilih pada pertemuan sebelumnya. Guru memberi kesempatan kepada siswa untuk berlatih sebelum tes dilakukan. Guru mulai menilai siswa per kelompok.Pada tahap ini, beberapa siswa ada yang terlihat konsentrasi tetapi ada juga yang masihkeliru dalam memainkan ansambel jawa. Guru menilai siswa sesuai dengan kondisi kemampuan siswa saat tes dilakukan. Saat tes berlangsung, masing-masing siswa ada yang terlihat serius dan ada juga yang mengobrol dengan teman-temanya saat menunggu giliran tes.

Setelah tes selesai, guru memberikan apresiasi dan memberi motivasi terhadap tes yang telah dilaksanakan. Siswa bersama guru menyimpulkan pembelajaran yang telah dilakukan. Siswa bersama guru merefleksi kegiatan pembelajaran yang telah dilakukan dan bersama-sama menutup pembelajaran.

\subsubsection{Penilaian}

Penilaian dilaksanakan selama proses dan sesudah pembelajaran. Dalam indikator pencapaian kompetensi yang dinilai adalah teknik (tes praktik kinerja) dan bentuk instrumen (tes uji petik kinerja). Format penilaian selama proses pembelajaran berlangsung adalah meliputi aspek-aspek sebagai berikut: kepanitiaan, kekompakan kelompok, kreativitas aransemen, dan kedisiplinan dalam berlatih. Penilaian menggunakan keterangan ceklis pada angka: angka 1=sangat kurang, 2=kurang, 3=cukup, 4=baik, 5=sangat baik. Pada aspek 
penilaian di atas, aspek kepanitiaan dan kreativitas aransemen tidak dipakai dalam proses evaluasi pembelajaran.

\subsubsection{Kesulitan yang Ditemui pada Siswa Kelas VIII C SMPN 22 Semarang dalam Mengekspresikan Diri melalui Karya Seni Musik}

Kesulitan yang ditemui siswa dalam pembelajaran mengekspresikan karya Seni Musik adalah sebagai berikut: a) tempo; mengatur tempo dalam memainkan ansambel musik menggunakan gamelan jawa bagi sebagian siswa sangat sulit, itu dikarenakan siswa tidak terbiasa memainkan gamelan jawa. Terlebih pada gamelan jawa satu penabuh dengan penabuh lain harus saling memperhatikan agar keserasian dan ketepatan nada bisa berjalan bersama-sama; b) artikulasi; kedisiplinan dalam memainkan artikulasi, panjang pendek nada pada saat memainkan ritme yang dimainkan secara bersamaan maupun pada saat memainkan melodi yang sama belum kompak sehingga bunyi yang dihasilkan kurang rapih dan bersih dalam bermain musik ansambel. Hal ini terjadi lantaran waktu latihan yang terbatas sehingga latihan lebih fokus pada ketepatan nada; c) interpretasi/pembawaan; pembawaan sulit dilakukan siswa saat memainkan lagu dengan alat musik, itu dikarenakan siswa kurang mempunyai rasa percaya diri. Selain itu juga banyak siswa yang masih belum mengenal alat musik gamelan jawa, karena mereka lebih sering memainkan alat musik modern.

\subsection{Faktor yang Mempengaruhi hasil Belajar Ansambel Musik}

Penelitian ini dilaksanakan di kelas VIII C SMPN 22 Semarang dengan jumlah responden yaitu 31 orang siswa. Faktor-faktor yang mempengaruhi hasil belajar ansambel musik di kelas VIII C disajikan dalam bentuk tabel dan gambar pada setiap indikator. Setiap indikator terdapat total pesentase siswa yang 
memilih jawaban selalu, sering, cukup, dan tidak pernah. Berikut ini disajikan hasil tanggapan siswa mengenai faktor-faktor yang memepengaruhi proses dan hasil belajar ansambel gamelan jawa.

\subsubsection{Indikator Perhatian Guru Seni Musik Terhadap Siswa}

Indiktor perhatian guru terhadap siswa terdapat pada butir soal ke 26 atas pernyataan "guru memperhatikan setiap siswa pada saat pembelajaran berlangsung”. Hasil jawaban siswa dapat dilihat pada tabel berikut.

Tabel 4.6 Indikator Perhatian Guru Seni Musik Terhadap Siswa

\begin{tabular}{|c|l|c|c|}
\hline No & Alternatif jawaban & Frekuensi & Persentasi \\
\hline 1. & Selalu & 15 & $48 \%$ \\
2. & Sering & 8 & $26 \%$ \\
3. & Kadang-kadang & 8 & $26 \%$ \\
4. & Tidak pernah & - & $0 \%$ \\
5. & Jumlah & 31 & $100 \%$ \\
\hline
\end{tabular}

Berdasarkan tabel hasil jawaban indikator perhatian guru seni musik terhadap siswamenunjukkan siswa yang memilih jawaban selalu adalah 15 orang atau sebesar $48 \%$. Jawaban sering dipilih oleh 8 orang atau sebesar $26 \%$. Jawaban kadang-kadang dipilih oleh 8 orang atau sebesar 26\%. Jawaban tidak pernah dipilih oleh 0 orang atau $0 \%$. Berdasarkan hasil tersebut dapat disimpulkan bahwa tanggapan siswa terhadap faktor-faktor yang mempengaruhi hasil belajar ansambel musik pada indikator perhatian guru seni musik terhadap siswa berada pada kualifikasi “ baik”. Sebab, presentase jawaban selalu dan sering dengan total $74 \%$ berada pada presentase $60 \%$ < sampai dengan $80 \%$. Sedangkan presentase jawaban kadang-kadang dan tidak pernah adalah $26 \%$. 
Berdasarkan pengamatan penulis saat proses pembelajaran, guru selalu memberi peringatan kepada siswa yang nilainya masih kurang agar belajar lebih giat dan serius lagi. Guru juga menunjukkan kedisiplinan yang tinggi saat proses pembelajaran sehingga siswa tidak malas-malasan dalam belajar. Hasil ini dapat dilihat pada gambar dibawah ini :

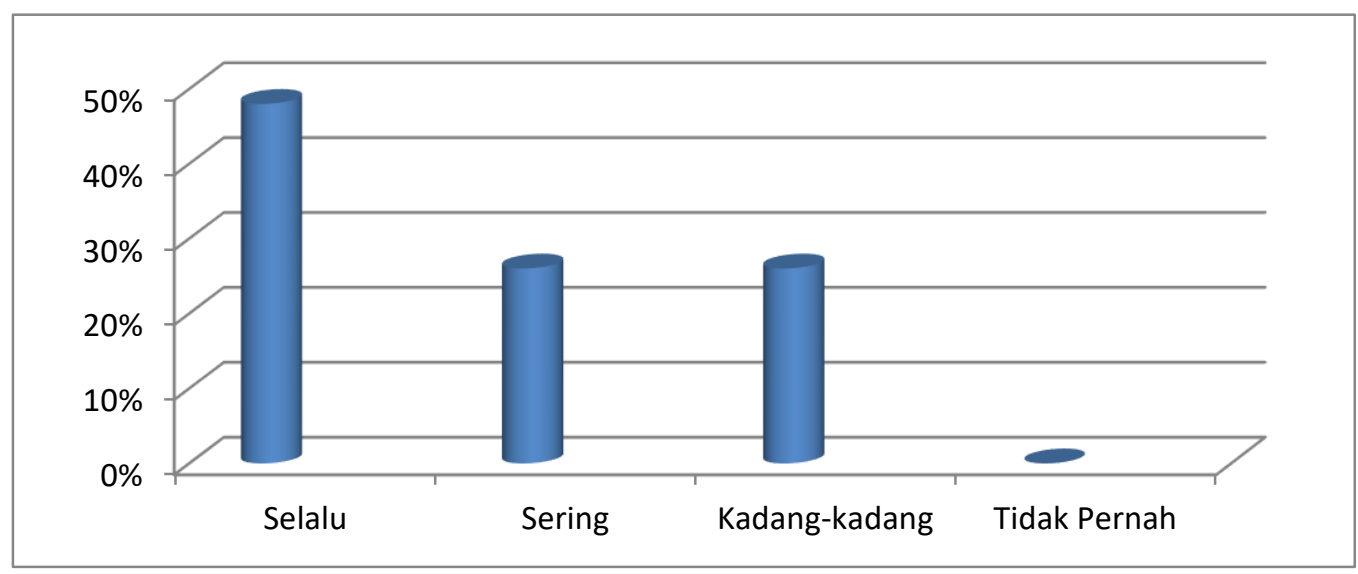

Gambar 4.2 Histogram Perhatian Guru Seni Musik terhadap Siswa

\subsubsection{Indikator Perhatian Guru dalam Memberikan Tugas Kepada Siswa}

Indikator perhatian guru dalam memberikan tugas kepada siswa terdapat pada butir soal ke 30 atas pernyataan "guru memberikan tugas tambahan yang harus dikerjakan di rumah" Hasil jawaban siswa dapat dilihat pada tabel berikut.

Tabel 4.7 Perhatian Guru dalam Memberikan Tugas Kepada Siswa

\begin{tabular}{|c|l|c|c|}
\hline No & \multicolumn{1}{|c|}{ Alternatif jawaban } & Frekuensi & Persentasi \\
\hline 1. & Selalu & 8 & $26 \%$ \\
2. & Sering & 10 & $33 \%$ \\
3. & Kadang-kadang & 11 & $35 \%$ \\
4. & Tidak pernah & 2 & $6 \%$ \\
5. & Jumlah & 31 & $100 \%$ \\
\hline
\end{tabular}


Berdasarkan tabel hasil jawaban indikator perhatian guru dalam memberikan tugas kepada siswa menunjukkan siswa yang memilih jawaban selalu adalah 15 orang atau sebesar 48\%. Jawaban sering dipilih oleh 8 orang atau sebesar $26 \%$. Jawaban kadang-kadang dipilih oleh 11 orang atau sebesar $35 \%$. Jawaban tidak pernah dipilih oleh 2 orang atau $6 \%$. Berdasarkan hasil tersebut dapat disimpulkan bahwa tanggapan siswa terhadap faktor-faktor yang mempengaruhi hasil belajar ansambel musik pada indikator perhatian guru dalam memberikan tugas kepada siswa berada pada kualifikasi “ cukup”. Sebab, presentase jawaban selalu dan sering dengan total $59 \%$ berada pada presentase $40 \%$ < sampai dengan $60 \%$. Sedangkan presentase jawaban kadang-kadang dan tidak pernah adalah $41 \%$. Berdasarkan data tersebut dapat disimpulkan bahwa tanggapan siswa terhadap pemberian tugas adalah cukup. Artinya tugas yang diberikan guru kepada siswa tidak mengganggu aktivitas siswa yang lain di luar sekolah. Hasil ini dapat dilihat pada gambar dibawah ini :

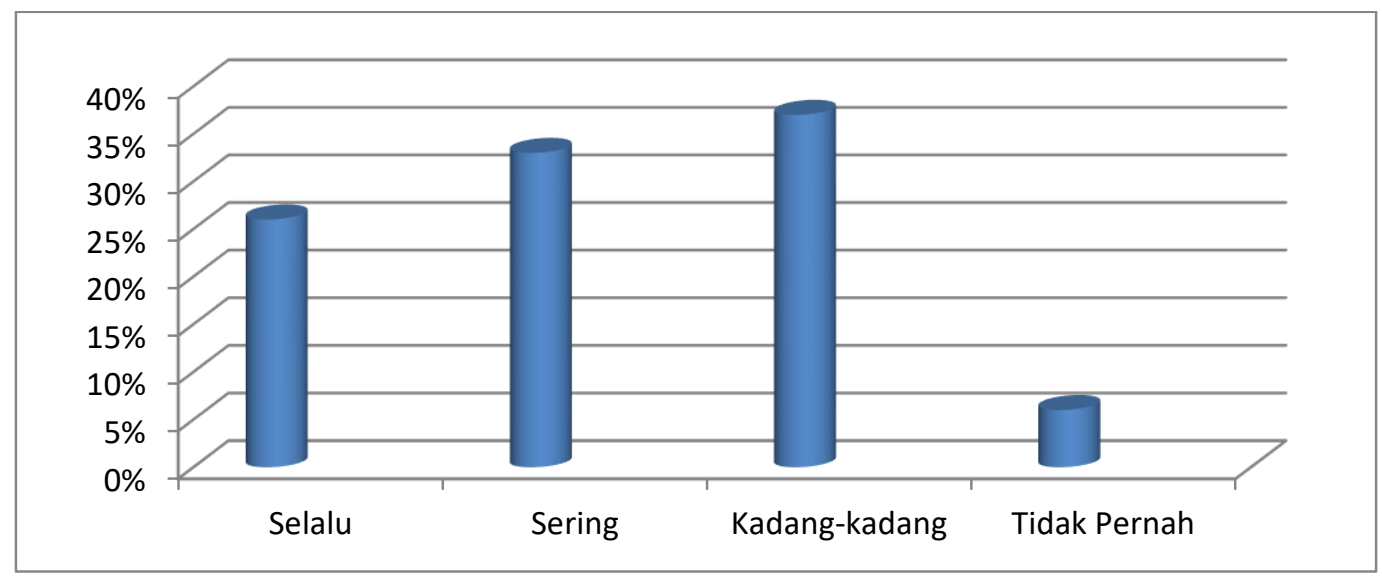

Gambar 4.3 Histogram Perhatian Guru dalam Memberikan Tugas Kepada Siswa 


\subsubsection{Indiktor Relasi Guru dengan Siswa}

Indikator relasi guru dengan siswa terdapat pada butir soal ke 16 atas pernyataan "guru seni musik mempunyai hubungan yang baik dengan siswa" Hasil jawaban siswa dapat dilihat pada tabel berikut ini.

Tabel 4.8 Relasi Guru dengan Siswa

\begin{tabular}{|c|l|c|c|}
\hline No & \multicolumn{1}{|c|}{ Alternatif jawaban } & Frekuensi & Persentasi \\
\hline 1. & Selalu & 14 & $45 \%$ \\
2. & Sering & 8 & $26 \%$ \\
3. & Kadang-kadang & 8 & $26 \%$ \\
4. & Tidak pernah & 1 & $3 \%$ \\
5. & Jumlah & 31 & $100 \%$ \\
\hline
\end{tabular}

Berdasarkan tabel pernyataan indikator relasi guru dengan siswa menunjukkan siswa yang memilih jawaban selalu adalah 14 orang atau sebesar 45\%. Jawaban sering dipilih oleh 8 orang atau sebesar 26\%. Jawaban kadangkadang dipilih oleh 8 orang atau sebesar 26\%. Jawaban tidak pernah dipilih oleh 1 orang atau 3\%. Berdasarkan hasil tersebut dapat disimpulkan bahwa tanggapan siswa terhadap faktor-faktor yang mempengaruhi hasil belajar ansambel musik pada indikator relasi guru dengan siswa berada pada kualifikasi " baik". Sebab, presentase jawaban selalu dan sering dengan total $71 \%$ berada pada presentase $60 \%$ < sampai dengan $80 \%$. Sedangkan presentase jawaban kadang-kadang dan tidak pernah adalah $29 \%$.

Relasi guru dengan siswa memberi pengaruh terhadap proses belajar dan hasil belajar siswa. Sikap guru yang menyenangkan, hangat, cinta persaudaraan, tidak menakutkan, dan sejenisnya serta menghindari sikap yang tidak disukai siswa dapat memperbaiki hubungan dengan siswa. Dengan cara seperti itu siswa akan terdorong untuk rajin belajar. Hubungan guru musik kelas VIII dengan siswa 
selama ini baik. Berdasarkan pengamatan peneliti, relasi guru seni musik kelas VIII dengan siswa cukup akrab, baik saat pembelajaran maupun saat di luar jam pelajaran. Siswa di kelas VIII C tidak ada yang bermasalah dengan guru seni musik. Siswa selalu menunjukkan kepatuhan terhadap guru dan mengikuti pembelajaran sesuai dengan arahan guru seni musik kelas VIII. Guru memberikan nilai kepada siswa berdasarkan atas kemampuan siswa dalam memainkan ansambel gamelan jawa. Hasil ini dapat dilihat pada gambar berikut :

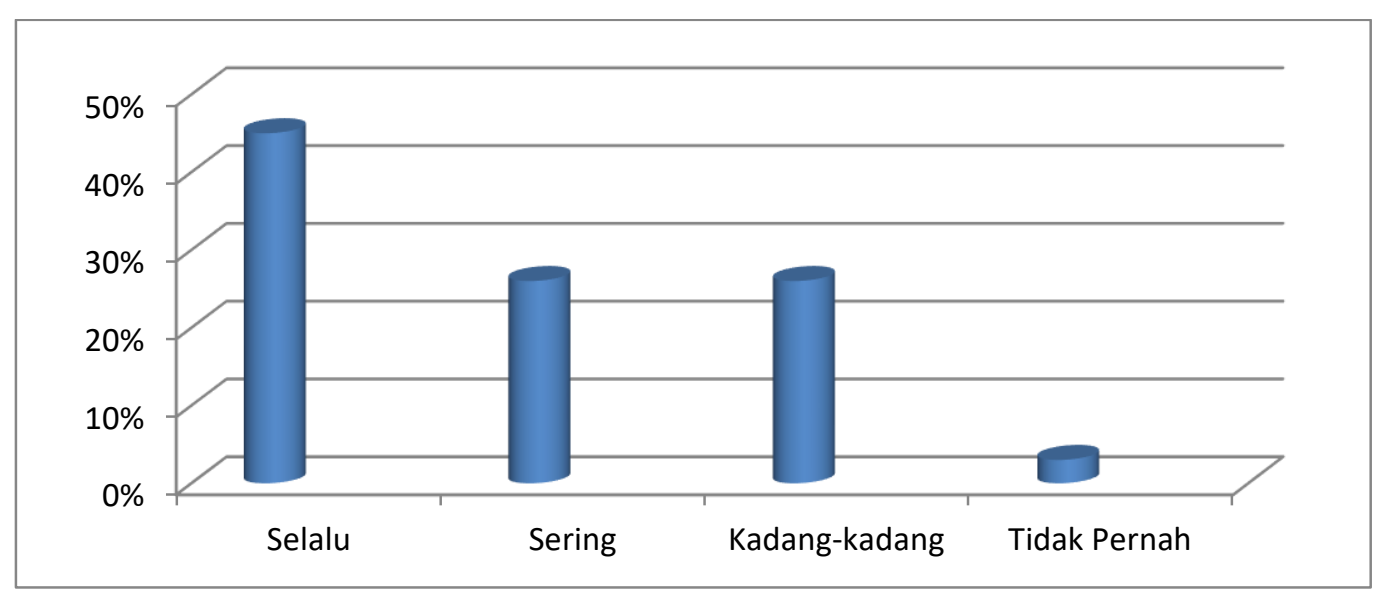

Gambar 4.4 Histogram Relasi Guru dengan Siswa

\subsubsection{Indikator Standar Pelajaran di atas Ukuran}

Indikator standar pelajaran di atas ukuran terdapat pada butir soal ke 20 atas pernyataan "siswa dapat menjawab pertanyaan yang diberikan oleh guru dengan baik" Hasil jawaban siswa dapat dilihat dalam tabel berikut.

Tabel 4.9 Standar Pelajaran di atas Ukuran

\begin{tabular}{|c|l|c|c|}
\hline No & \multicolumn{1}{|c|}{ Alternatif jawaban } & Frekuensi & Persentasi \\
\hline 1. & Selalu & 4 & $13 \%$ \\
2. & Sering & 8 & $26 \%$ \\
3. & Kadang-kadang & 19 & $61 \%$ \\
4. & Tidak pernah & 0 & $0 \%$ \\
5. & Jumlah & 31 & $100 \%$ \\
\hline
\end{tabular}


Berdasarkan tabel pernyataan indikator standar pelajaran di atas ukuran menunjukkan siswa yang memilih jawaban selalu adalah 4 orang atau sebesar 13\%. Jawaban sering dipilih oleh 8 orang atau sebesar $26 \%$. Jawaban kadangkadang dipilih oleh 19 orang atau sebesar $61 \%$. Jawaban tidak pernah dipilih oleh 0 orang atau $0 \%$. Berdasarkan hasil tersebut dapat disimpulkan bahwa tanggapan siswa terhadap faktor-faktor yang mempengaruhi hasil belajar ansambel musik pada indikator standar pelajaran di atas ukuran berada pada kualifikasi " kurang baik". Sebab, presentase jawaban selalu dan sering dengan total 39\% berada pada presentase $20 \%$ < sampai dengan $40 \%$. Sedangkan presentase jawaban kadangkadang dan tidak pernah adalah $61 \%$. Standar pelajaran hendaknya disesuaikan dengan ukuran kemampuan siswa.

Standar pelajaran hendaknya disesuaikan dengan kemampuan siswa supaya tujuan pembelajaran dapat tercapai. Apabila guru terlalu memaksakan siswa untuk menguasai pelajaran diatas kemampuan rata-rata mereka maka pembelajaran akan sulit untuk dikuasai dan tujuan pembelajaran sulit tercapai. Berdasarkan pengamatan peneliti mengenai hasil tersebut ada beberapa siswa yang kurang memahami apa yang diajarkan oleh guru. Namun sebagian lainya mampu mengikuti pelajaran dengan baik terutama pada pembelajaran praktik memainkan ansambel gamelan jawa. Hasil ini dapat dilihat pada gambar berikut. 


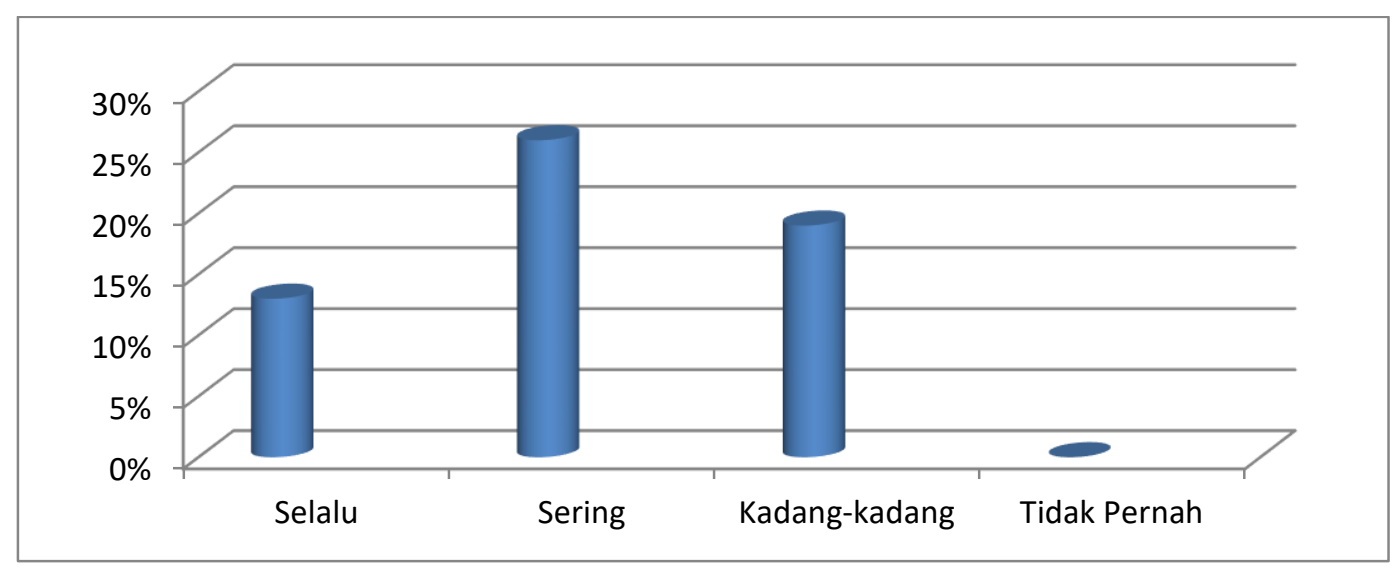

Gambar 4.5 Histogram Standar Pelajaran di atas Ukuran

\subsubsection{Indikator Standar Kurikulum di Sekolah}

Indikator standar kurikulum di sekolah terdapat pada butir soal ke 25 atas pernyataan "rata-rata siswa dapat mengikuti pelajaran yang diberikan sekolah dengan baik" Hasil jawaban siswa dapat dilihat pada tabel berikut.

Tabel 4.10 Standar Kurikulum di Sekolah

\begin{tabular}{|c|l|c|c|}
\hline No & \multicolumn{1}{|c|}{ Alternatif jawaban } & Frekuensi & Persentasi \\
\hline 1. & Selalu & 13 & $42 \%$ \\
2. & Sering & 12 & $39 \%$ \\
3. & Kadang-kadang & 6 & $19 \%$ \\
4. & Tidak pernah & 0 & $0 \%$ \\
5. & Jumlah & 31 & $100 \%$ \\
\hline
\end{tabular}

Berdasarkan tabel pernyataan indikator standar kurikulum di sekolah menunjukkan siswa yang memilih jawaban selalu adalah 13 orang atau sebesar 42\%. Jawaban sering dipilih oleh 12 orang atau sebesar 39\%. Jawaban kadangkadang dipilih oleh 6 orang atau sebesar 19\%. Jawaban tidak pernah dipilih oleh 0 orang atau 0\%. Berdasarkan hasil tersebut dapat disimpulkan bahwa tanggapan siswa terhadap faktor-faktor yang mempengaruhi hasil belajar ansambel musik pada indikator standar kurikulum di sekolah berada pada kualifikasi "sangat 
baik". Sebab, presentase jawaban selalu dan sering dengan total $81 \%$ berada pada presentase $80 \%$ < sampai dengan $100 \%$. Sedangkan presentase jawaban kadangkadang dan tidak pernah adalah $19 \%$.

Kurikulum hendakanya dibuat sesuai dengan kemampuan dan karakter siswa serta perencanaan yang mendetail sehingga dapat melayani belajar siswa baik secara kelompok maupun secara individual. Kurikulum yang dibuat terlalu padat, tidak sesuai dengan kemampuan rata-rata siswa dan tidak sesuai dengan bakat dan minat siswa termasuk kurikulum yang tidak baik (Slameto, 2010:66). Berdasarkan pengamatan peneliti, kurikulum yang digunakan pada kelas VIII adalah kurikulum tingkat satuan pendidikan (KTSP). Berdasarkan pengamatan peneliti terhadap hasil tersebut siswa selalu terlihat ceria dan semangat saat mengikuti setiap pembelajaran yang dilakukan. Apabila waktunya pelajaran dimulai siswa terlihat tertib dan siap mengikuti pembelajaran. Hasil ini dapat dilihat pada gambar berikut.

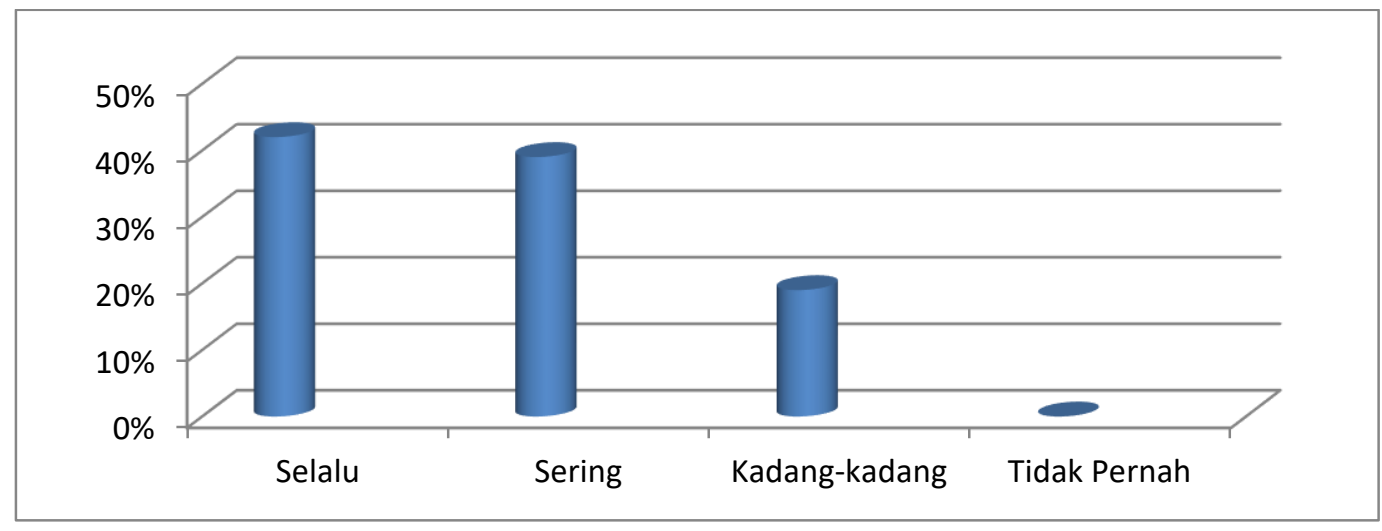

Gambar 4.6 Histogram Standar Kurikulum bagi Siswa 


\subsubsection{Indikator Keadaan Gedung}

Indikator keadaan gedung terdapat pada butir soal ke 1 atas pernyataan "suasana disekitar terasa nyaman" Hasil jawaban siswa dapat dilihat dalam tabel berikut.

Tabel 4.11 Keadaan Gedung

\begin{tabular}{|c|l|c|c|}
\hline No & \multicolumn{1}{|c|}{ Alternatif jawaban } & Frekuensi & Persentasi \\
\hline 1. & Selalu & 6 & $19 \%$ \\
2. & Sering & 8 & $26 \%$ \\
3. & Kadang-kadang & 17 & $55 \%$ \\
4. & Tidak pernah & - & $0 \%$ \\
5. & Jumlah & 31 & $100 \%$ \\
\hline
\end{tabular}

Berdasarkan tabel pernyataan indikator keadaan gedung di sekolah menunjukkan siswa yang memilih jawaban selalu adalah 6 orang atau sebesar 19\%. Jawaban sering dipilih oleh 8 orang atau sebesar 26\%. Jawaban kadangkadang dipilih oleh 17 orang atau sebesar 55\%. Jawaban tidak pernah dipilih oleh 0 orang atau $0 \%$. Berdasarkan hasil tersebut dapat disimpulkan bahwa tanggapan siswa terhadap faktor-faktor yang mempengaruhi hasil belajar ansambel musik pada indikator keadaan gedung di sekolah berada pada kualifikasi “cukup". Sebab, presentase jawaban selalu dan sering dengan total $45 \%$ berada pada presentase $40 \%$ < sampai dengan $60 \%$. Sedangkan presentase jawaban kadangkadang dan tidak pernah adalah 55\%.

Keadaan gedung untuk belajar hendaknya layak untuk digunakan belajar. Keadaan gedung yang rusak akan menghambat proses belajar mengajar. Gedung yang layak untuk belajar misalkan kondisinya aman dari kebocoran, ventilasi udaranya cukup dan suasananya tidak bising sehingga nyaman untuk belajar. 
Berdasarkan pengamatan peneliti terhadap keadaan gedung di sekolah tersebut, keadaan gedung masih bagus dan kuat akan tetapi, jarak antara bagian gedung yang satu dengan yang lainya sangat dekat dan hampir setiap lokasi terdapat bangunan. Pemilihan gedung atau ruangan bermain musik juga kurang tepat karena selain ruangan tidak kedap suara juga sangat dekat atau bersebelahan dengan ruang kelas. Sehingga kurang efektif untuk proses belajar mengajar di sekolah tersebut. Hasil ini dapat dilihat pada gambar berikut.

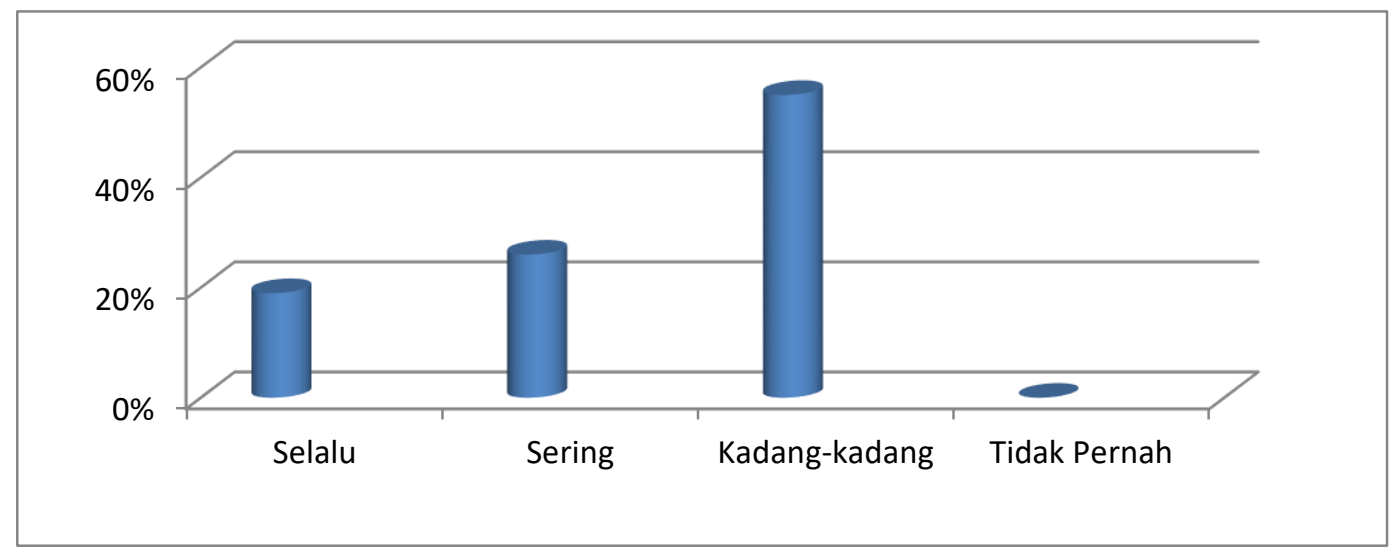

Gambar 4.7 Histogram Keadaan Gedung

\subsubsection{Indikator Alat Pelajaran}

Indikator alat pelajaran terdapat pada butir soal ke 5 atas pernyataan "sarana dan prasarana di sekolah memadai" Hasil jawaban siswa dapat dilihat pada tabel berikut.

Tabel 4.12 Alat Pelajaran

\begin{tabular}{|c|l|c|c|}
\hline No & \multicolumn{1}{|c|}{ Alternatif Jawaban } & Frekuensi & Persentasi \\
\hline 1. & Selalu & 16 & $52 \%$ \\
2. & Sering & 9 & $29 \%$ \\
3. & Kadang-kadang & 6 & $19 \%$ \\
4. & Tidak pernah & - & $0 \%$ \\
5. & Jumlah & 31 & $100 \%$ \\
\hline
\end{tabular}


Berdasarkan tabel pernyataan indikator alat pelajaran di sekolah menunjukkan siswa yang memilih jawaban selalu adalah 16 orang atau sebesar 52\%. Jawaban sering dipilih oleh 9 orang atau sebesar 29\%. Jawaban kadangkadang dipilih oleh 6 orang atau sebesar 19\%. Jawaban tidak pernah dipilih oleh 0 orang atau 0\%. Berdasarkan hasil tersebut dapat disimpulkan bahwa tanggapan siswa terhadap faktor-faktor yang mempengaruhi hasil belajar ansambel musik pada indikator alat pelajaran di sekolah berada pada kualifikasi "sangat baik". Sebab, presentase jawaban selalu dan sering dengan total $81 \%$ berada pada presentase $80 \%$ < sampai dengan $100 \%$. Sedangkan presentase jawaban kadangkadang dan tidak pernah adalah $29 \%$.

Alat pelajaran mempunyai peran penting dalam proses pembelajaran. Alat pelajaran dapat membantu proses pembelajaran menjadi lebih baik dan lebih optimal. Alat-alat yang dibutuhkan dalam pembelajaran misalnya papan tulis, penghapus, spidol, proyektor, LKS dan sebagainya. Dalyono (2007:244) mengatakan timbulnya alat pelajaran akan menentukan; 1) perubahan metode mengajar guru; 2) segi dalamnya ilmu pengetahuan pada pikiran anak; 3) memenuhi tuntutan dari bermacam-macam tipe anak. Berdasarkan pengamatan peneliti, alat yang disediakan di sekolah tersebut cukup lengkap terutama alat untuk belajar musik. Sekolah menyediakan dua ruangan yang khusus digunakan untuk menampung alat-alat musik yang dibutuhkan dalam pembelajaran. Ruangan yang pertama digunakan untuk menampung alat-alat musik gamelan dan ruangan kedua ukuranya lebih luas dari ruang gamelan sekitar 8x9 meter dan digunakan untuk menyimpan alat-alat musik tradisional dan modern seperti rebana, 
seperangkat alat musik band, sejumlah pianika, sejumlah secorder, sejumlah gitar klasik, sound sistem dan sebagainya. Hasil ini dapat dilihat pada gambar dibawah ini:

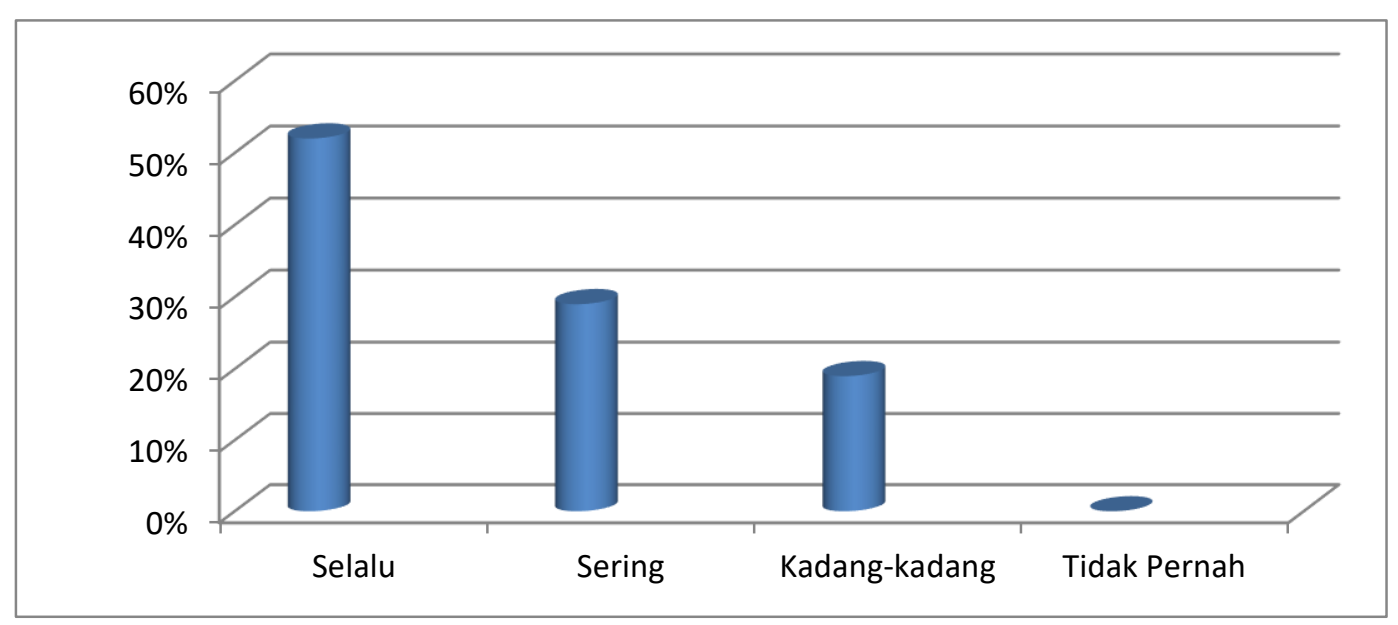

Gambar 4.8 Histogram Alat Pelajaran

\subsubsection{Indikator Bakat Siswa}

Indikator bakat siswa terdapat pada butir soal ke 2 atas pernyataan "materi pembelajaran ansambel seni musik ini lebih mudah dipahami" Hasil jawaban siswa dapat dilihat dalam tabel berikut.

Tabel 4.13 Bakat Siswa

\begin{tabular}{|c|l|c|c|}
\hline No & \multicolumn{1}{|c|}{ Alternatif Jawaban } & Frekuensi & Persentasi \\
\hline 1. & Selalu & 7 & $22 \%$ \\
2. & Sering & 13 & $42 \%$ \\
3. & Kadang-kadang & 11 & $36 \%$ \\
4. & Tidak pernah & 0 & $0 \%$ \\
5. & Jumlah & 31 & $100 \%$ \\
\hline
\end{tabular}

Berdasarkan tabel pernyataan indikator bakat siswa menunjukkan siswa yang memilih jawaban selalu adalah 7 orang atau sebesar $22 \%$. Jawaban sering dipilih oleh 13 orang atau sebesar 42\%. Jawaban kadang-kadang dipilih oleh 11 orang atau sebesar $36 \%$. Jawaban tidak pernah dipilih oleh 0 orang atau $0 \%$. 
Berdasarkan hasil tersebut dapat disimpulkan bahwa tanggapan siswa terhadap faktor-faktor yang mempengaruhi hasil belajar ansambel musik pada indikator bakat siswa berada pada kualifikasi "baik". Sebab, presentase jawaban selalu dan sering dengan total $64 \%$ berada pada presentase $60 \%<$ sampai dengan $80 \%$. Sedangkan presentase jawaban kadang-kadang dan tidak pernah adalah $36 \%$.

Bakat adalah potensi/kecakapan dasar yang dibawa sejak lahir. Setiap individu mempunyai bakat yang berbeda-beda. Menurut Dalyono (2007:50) orang tua yang berkecimpung di bidang kesenian, anaknya akan mudah mempelajari seni suara, tari, dan lain-lain. Jadi, seseorang akan mudah mempelajari yang sesuai dengan bakatnya. Apabila seorang anak harus mempelajari bahan yang lain dari bakatnya ia akan cepat bosan, mudah putus asa, dan tidak senang. Berdasarkan pengamatan penulis, kebanyakan siswa tertarik dan suka bernyanyi atau bermusik namun untuk bisa menguasai keterampilan dalam bermain ansambel gamelan jawa setiap siswa mempunyai kapasitasnya masingmasing dan kekuatan bakat masing-masing siswa juga berbeda. Jadi ada yang dengan mudah dan cepat dalam menguasai materi dan juga ada pula yang lambat. Hasil ini dapat dilihat pada gambar berikut :

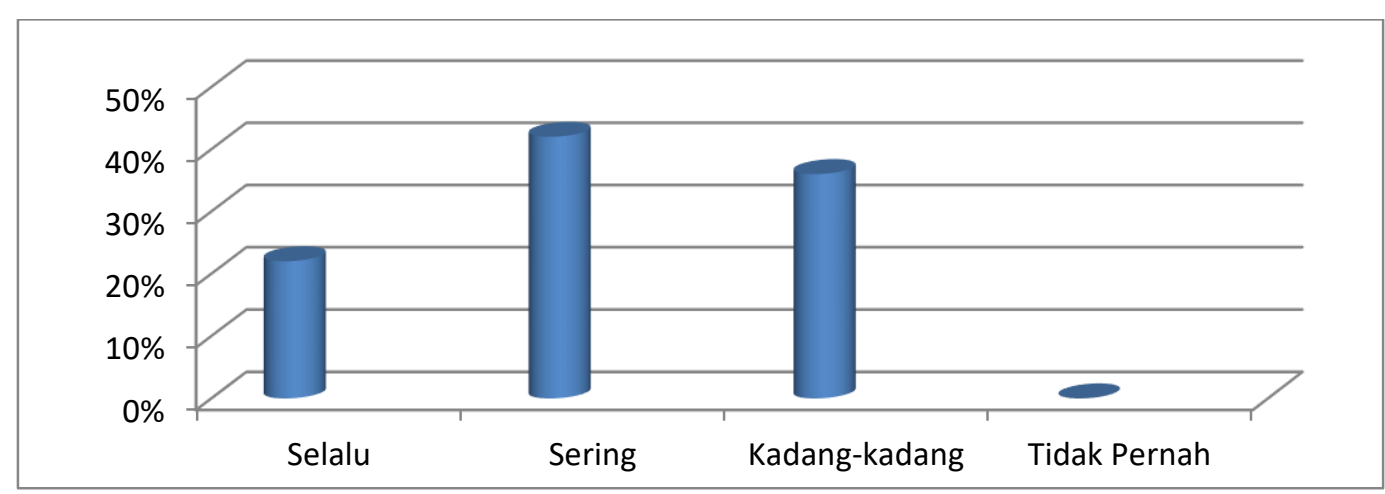

Gambar 4.9 Histogram Bakat 


\subsubsection{Indikator Minat Siswa}

Indikator minat siswa terdapat pada butir soal ke 19 atas pernyataan "mengikuti pembelajaran Ansambel Musik dengan semangat dan sepenuh hati" Hasil jawaban siswa dapat dilihat pada tabel berikut.

Tabel 4.14 Minat Siswa

\begin{tabular}{|c|l|c|c|}
\hline No & \multicolumn{1}{|c|}{ Alternatif jawaban } & Frekuensi & Persentasi \\
\hline 1. & Selalu & 12 & $39 \%$ \\
2. & Sering & 8 & $26 \%$ \\
3. & Kadang-kadang & 11 & $35 \%$ \\
4. & Tidak pernah & 0 & $0 \%$ \\
5. & Jumlah & 31 & $100 \%$ \\
\hline
\end{tabular}

Berdasarkan tabel pernyataan indikator minat siswa menunjukkan pilihan jawaban selalu dipilih oleh 12 siswa atau sebesar 39\%. Jawaban sering dipilih oleh 8siswa atau sebesar 26\%. Jawaban kadang-kadang dipilih oleh 11 siswa atau sebesar 35\%. Jawaban tidak pernah dipilih oleh 0 siswa atau 0\%. Berdasarkan hasil tersebut dapat disimpulkan bahwa tanggapan siswa terhadap faktor-faktor yang mempengaruhi hasil belajar ansambel musik pada indikator minat siswa berada pada kualifikasi "baik". Sebab, presentase jawaban selalu dan sering dengan total $65 \%$ berada pada presentase $60 \%$ < sampai dengan $80 \%$. Sedangkan presentase jawaban kadang-kadang dan tidak pernah adalah $35 \%$.

Minat datang dari dalam hati sanubari siswa. Dengan adanya minat seseorang dapat melakukan hal yang diminati dengan rasa senang. Berdasarkan pengamatan peneliti, kebanyakan siswa terlihat antusias dan berusaha untuk bisa memainkan ansambel gamelan jawa. Minat ini sangat penting dimiliki oleh siswa, sebab dengan adanya minat pada diri siswa, siswa akan melakukan apa yang 
menjadi minatnya dengan rasa senang. Hasil ini dapat dilihat pada gambar berikut

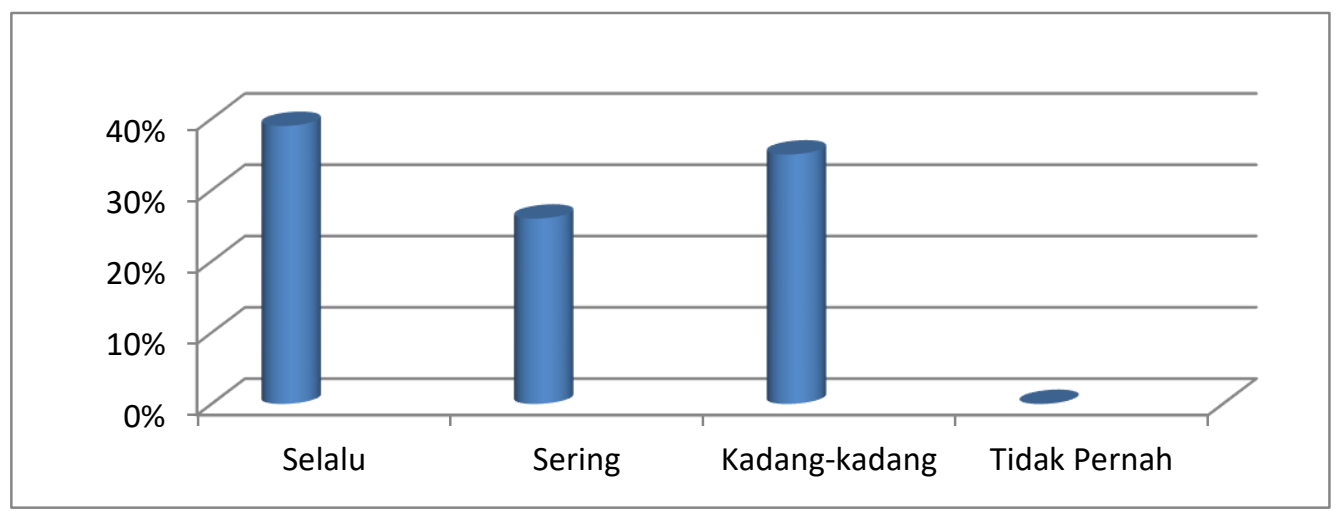

Gambar 4.10 Histogram Minat

\subsubsection{Indikator Perhatian Siswa}

Indikator perhatian siswa terdapat pada butir soal ke 11 atas pernyataan "memperhatikan pembelajaran ansambel musik yang disampaikan oleh guru". Hasil jawaban siswa dapat dilihat pada tabel berikut.

Tabel 4.15 Perhatian Siswa

\begin{tabular}{|c|l|c|c|}
\hline No & \multicolumn{1}{|c|}{ Alternatif jawaban } & Frekuensi & Persentasi \\
\hline 1. & Selalu & 8 & $26 \%$ \\
2. & Sering & 13 & $42 \%$ \\
3. & Kadang-kadang & 10 & $32 \%$ \\
4. & Tidak pernah & 0 & $0 \%$ \\
5. & Jumlah & 31 & $100 \%$ \\
\hline
\end{tabular}

Berdasarkan tabel pernyataan indikator perhatian siswa menunjukkan siswa yang memilih jawaban selalu adalah 8 orang atau sebesar $26 \%$. Jawaban sering dipilih oleh 13 orang atau sebesar 42\%. Jawaban kadang-kadang dipilih oleh 10 orang atau sebesar $32 \%$. Jawaban tidak pernah dipilih oleh 0 orang atau 0\%. Berdasarkan hasil tersebut dapat disimpulkan bahwa tanggapan siswa 
terhadap faktor-faktor yang mempengaruhi hasil belajar ansambel musik pada indikator perhatian siswa berada pada kualifikasi "baik". Sebab, presentase jawaban selalu dan sering dengan total $68 \%$ berada pada presentase $60 \%$ < sampai dengan $80 \%$. Sedangkan presentase jawaban kadang-kadang dan tidak pernah adalah $32 \%$.

Perhatian dikatakan dapat mempengaruhi proses dan hasil belajar siswa. Perhatian adalah sebuah perasaan dan keyakinan yang kuat terhadap sesuatu yang ditunjukkan dengan rasa ingin tahu yang tinggi. Apabila siswa mempunyai perhatian maka akan cepat memancing respon siswa sehingga proses belajar pada siswa akan semakin cepat. Berdasarkan pengamatan peneliti terhadap siswa kelas VIII C, dari antusiasnya siswa untuk bisa memainkan ansambel gamelan jawa dengan benar menunjukkan bahwa siswa mempunyai perhatian terhadap ansambel gamelan jawa. Dengan begitu dapat disimpulkan bahwa perhatian siswa terhadap ansambel gamelan jawa di kelas VIII C SMPN 22 Semarang sudah baik. Hasil ini dapat dilihat pada gambar berikut :

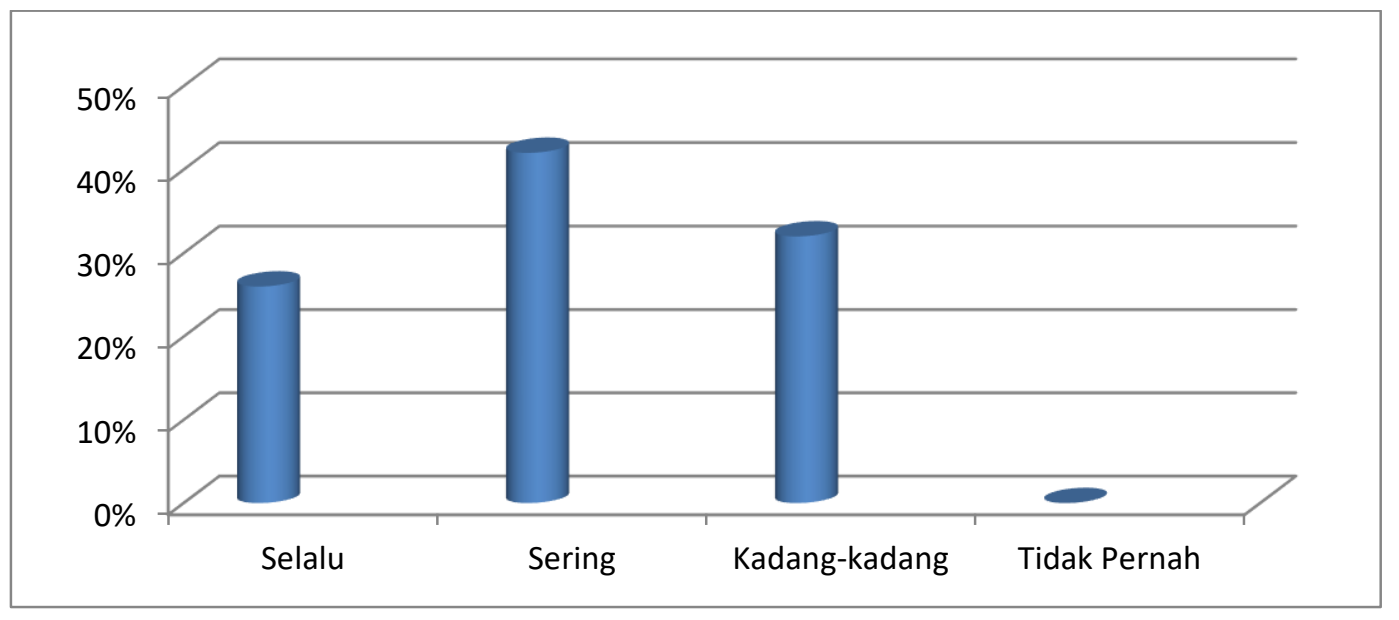

Gambar 4.11 Histogram Perhatian Siswa 


\subsubsection{Indikator Keseriusan /Minat Siswa}

Indikator keseriusan /minat siswa terdapat pada butir soal ke 4 atas pernyataan "siswa bercanda ketika proses belajar dikelas". Hasil jawaban siswa dapat dilihat dalam tabel berikut.

Tabel 4.16 Keseriusan/Minat Siswa

\begin{tabular}{|c|l|c|c|}
\hline No & \multicolumn{1}{|c|}{ Alternatif jawaban } & Frekuensi & Persentasi \\
\hline 1. & Selalu & 3 & $10 \%$ \\
2. & Sering & 14 & $45 \%$ \\
3. & Kadang-kadang & 13 & $42 \%$ \\
4. & Tidak pernah & 1 & $3 \%$ \\
5. & Jumlah & 31 & $100 \%$ \\
\hline
\end{tabular}

Berdasarkan tabel pernyataan indikator keseriusan/minat siswa menunjukkan siswa yang memilih jawaban selalu adalah 3 orang atau sebesar 10\%. Jawaban sering dipilih oleh 14 orang atau sebesar $45 \%$. Jawaban kadangkadang dipilih oleh 13 orang atau sebesar $42 \%$. Jawaban tidak pernah dipilih oleh 1 orang atau $3 \%$. Berdasarkan hasil tersebut dapat disimpulkan bahwa tanggapan siswa terhadap faktor-faktor yang mempengaruhi hasil belajar ansambel musik pada indikator keseriusan/minat siswa berada pada kualifikasi "cukup". Sebab, presentase jawaban selalu dan sering dengan total $55 \%$ berada pada presentase $40 \%$ <ampai dengan $60 \%$. Sedangkan presentase jawaban kadang-kadang dan tidak pernah adalah $45 \%$. Berdasarkan hasil tersebut keseriusan siswa terbilang masih belum kondusif. Siswa masih belum serius untuk mempelajari ansambel musik. Diduga keseriusan siswa dipengaruhi oleh anggapan siswa bahwa pembelajaran ansambel seni musik adalah sebuah pembelajaran yang tidak di UAN kan, sehingga tidak terlalu perlu untuk serius dalam mengusainya. Hasil ini dapat dilihat pada gambar berikut : 


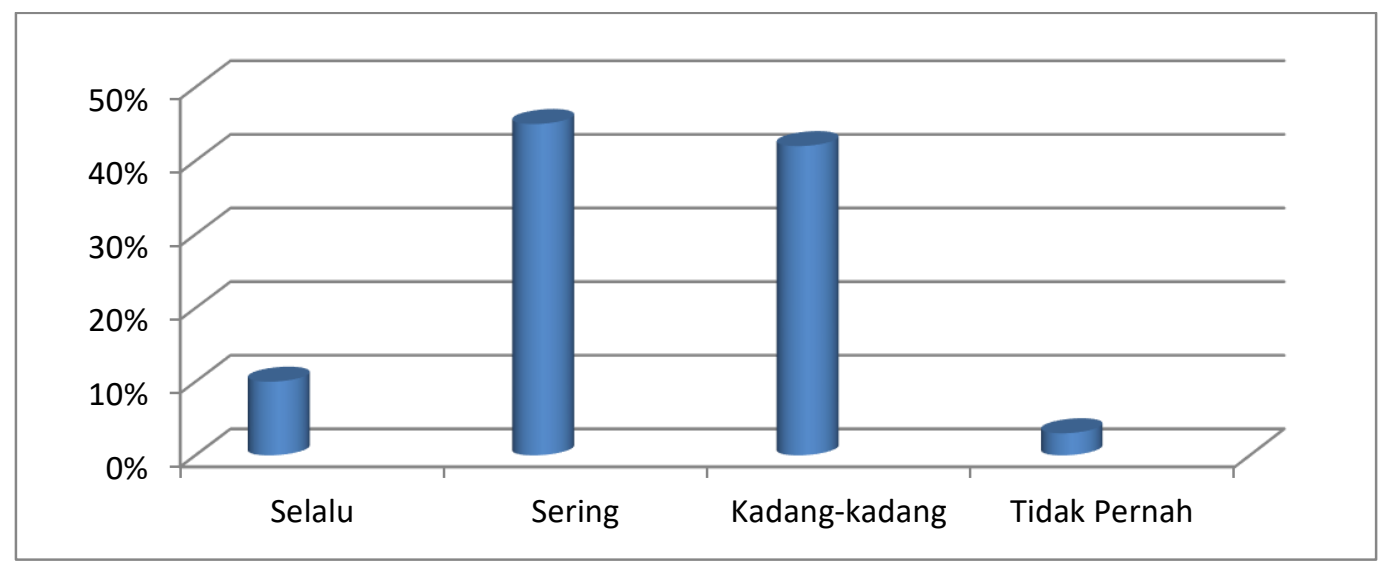

Gambar 4.12 Histogram Minat Siswa

\subsubsection{Indikator Motif Siswa}

Indikator motif siswa terdapat pada butir soal ke 3 atas pernyataan "rasa ingin tahu siswa tergerak oleh pertanyaan yang dikemukakan dan masalah yang diberikan guru pada materi pembelajaran seni musik" Hasil jawaban siswa dapat dilihat dalam tabel berikut.

Tabel 4.17 Motif Siswa

\begin{tabular}{|c|l|c|c|}
\hline No & \multicolumn{1}{|c|}{ Alternatif jawaban } & Frekuensi & Persentasi \\
\hline 1. & Selalu & 5 & $16 \%$ \\
2. & Sering & 9 & $29 \%$ \\
3. & Kadang-kadang & 14 & $45 \%$ \\
4. & Tidak pernah & 3 & $10 \%$ \\
5. & Jumlah & 31 & $100 \%$ \\
\hline
\end{tabular}

Berdasarkan tabel pernyataan indikator motif siswa menunjukkan siswa yang memilih jawaban selalu adalah 5 orang atau sebesar $16 \%$. Jawaban sering dipilih oleh 9 orang atau sebesar 29\%. Jawaban kadang-kadang dipilih oleh 14 orang atau sebesar $45 \%$. Jawaban tidak pernah dipilih oleh 3 orang atau $10 \%$. Berdasarkan hasil tersebut dapat disimpulkan bahwa tanggapan siswa terhadap faktor-faktor yang mempengaruhi hasil belajar ansambel musik pada indikator 
motif siswa berada pada kualifikasi "cukup". Sebab, presentase jawaban selalu dan sering dengan total $45 \%$ berada pada presentase $40 \%<$ sampai dengan 60\%.Sedangkan presentase jawaban kadang-kadang dan tidak pernah adalah 55\%.

Motifasi merupakan sebuah dorongan untuk melakukan sesuatu. Semakin besar motivasi maka akan semakin besar pula ketahanan siswa dalam menghadapi tantangan dalam proses belajarnya untuk mencapai apa yang menjadi tujuan dalam belajarnya. Untuk itu, keberadaan motivasi sangat penting dalam mendukung proses belajar siswa. Dari hasil tersebut dapat disimpulkan bahwa motivasi siswa untuk belajar ansambel gamelan jawa masih belum kondusif. Artinya motivasi belajar siswa masih kurang dalam mempelajari ansambel gamelan jawa. Hasil ini dapat dilihat pada gambar berikut :

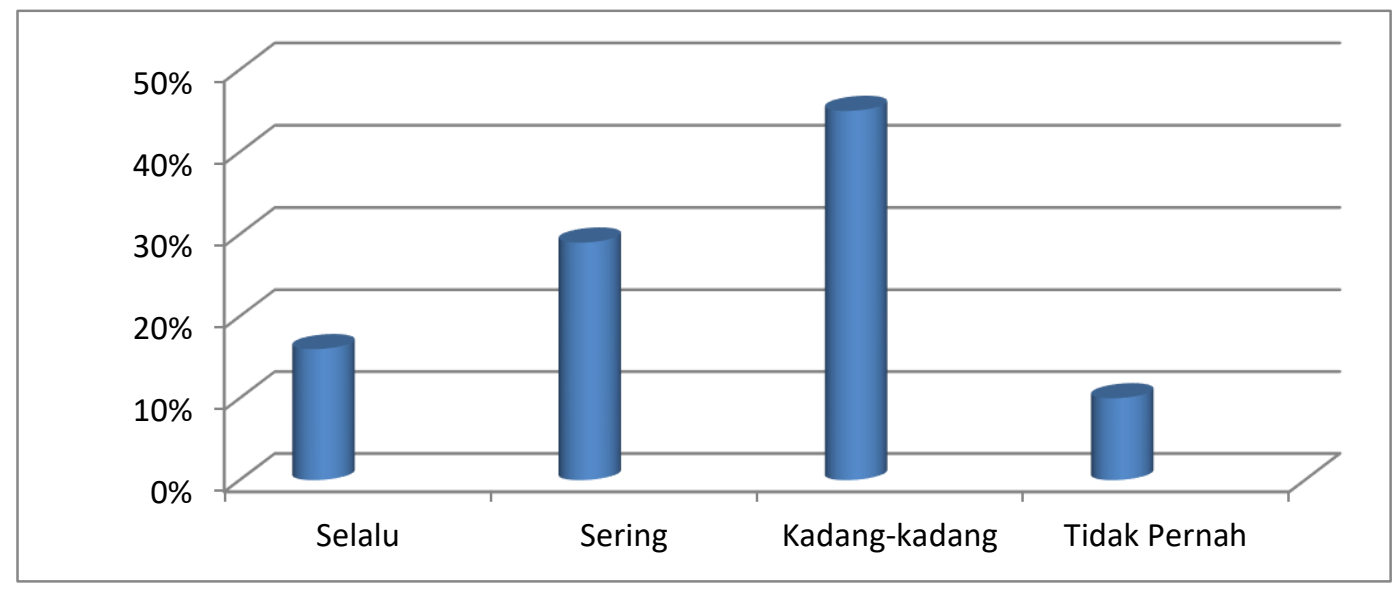

Gambar 4.13 Histogram Motif Siswa

\subsubsection{Indikator Disiplin Sekolah}

Indikator disiplin sekolah terdapat pada butir soal ke 9 atas pernyataan "datang ke sekolah tepat waktu" Hasil jawaban siswa dapat dilihat dalam tabel berikut. 
Tabel 4.18 Disiplin Sekolah

\begin{tabular}{|c|l|c|c|}
\hline No & \multicolumn{1}{|c|}{ Alternatif jawaban } & Frekuensi & Persentasi \\
\hline 1. & Selalu & 15 & $48 \%$ \\
2. & Sering & 9 & $29 \%$ \\
3. & Kadang-kadang & 7 & $23 \%$ \\
4. & Tidak pernah & - & $0 \%$ \\
5. & Jumlah & 31 & $100 \%$ \\
\hline
\end{tabular}

Berdasarkan tabel pernyataan indikator disiplin sekolah menunjukkan siswa yang memilih jawaban selalu adalah 15 orang atau sebesar $48 \%$. Jawaban sering dipilih oleh 9 orang atau sebesar 29\%. Jawaban kadang-kadang dipilih oleh 7 orang atau sebesar $23 \%$. Jawaban tidak pernah dipilih oleh 0 orang atau $0 \%$. Berdasarkan hasil tersebut dapat disimpulkan bahwa tanggapan siswa terhadap faktor-faktor yang mempengaruhi hasil belajar ansambel musik pada indikator disiplin sekolah berada pada kualifikasi "baik". Sebab, presentase jawaban selalu dan sering dengan total $77 \%$ berada pada presentase $60 \%$ < sampai dengan $80 \%$. Sedangkan presentase jawaban kadang-kadang dan tidak pernah adalah $23 \%$.

Kedisiplinan di sekolah mempengaruhi sikap siswa dalam belajar. Disiplin di sekolah merupakan suatu yang wajib ditegakkan. Sebab dengan disiplinlah nilai pendidikan dapat terwujud. Dengan disiplin diharapkan tujuan pembelajaran tercapai. Berdasarkan pengamatan peneliti, sekolah mempunyai kedisiplinan yang tinggi. Dapat dilihat pada setiap harinya siswa berangkat ke sekolah sangat pagi dan guru juga demikian. Jarang ada siswa yang telat ke sekolah. Baik pegawai maupun guru di sekolah selalu menerapkan kedisiplinan yang tinggi dalam berbagai kegiatan di sekolah. Hasil ini dapat dilihat pada gambar dibawah ini : 


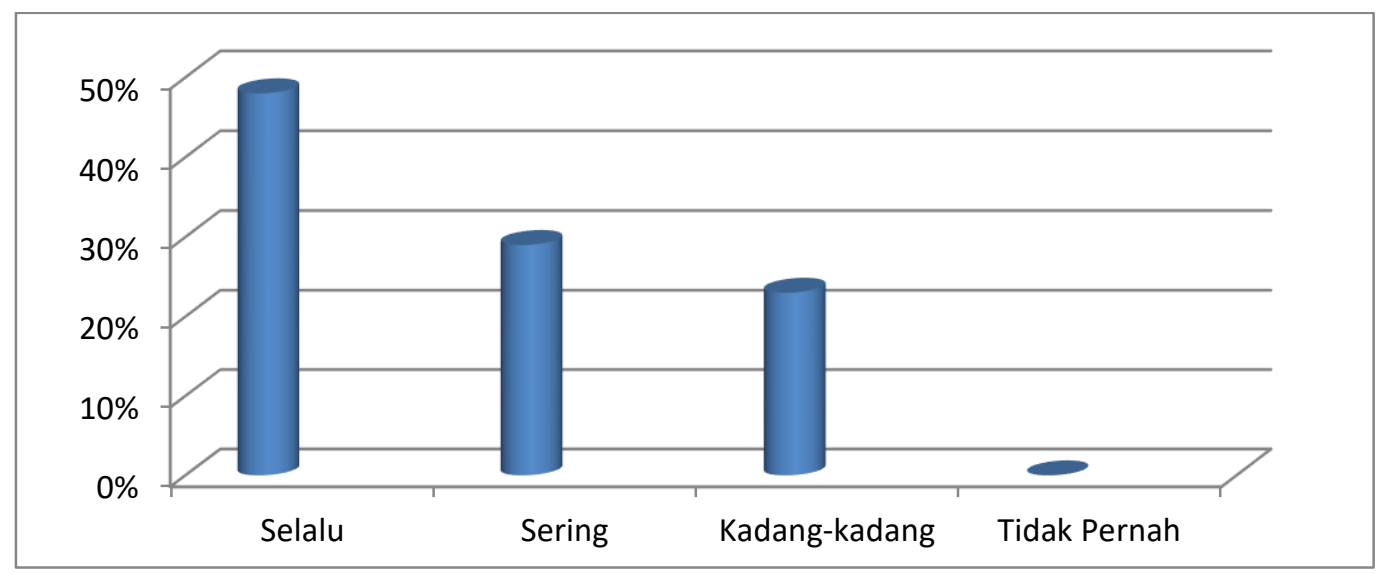

Gambar 4.14 Histogram Disiplin Sekolah

\subsubsection{Indikator Kesehatan Siswa}

Indikator kesehatan siswa terdapat pada butir soal ke 13 atas pernyataan "mengalami gangguan kesehatan ketika pembelajaran berlangsung". Hasil jawaban siswa dapat dilihat dalam tabel berikut.

Tabel 4.19 Kesehatan Siswa

\begin{tabular}{|c|l|c|c|}
\hline No & \multicolumn{1}{|c|}{ Alternatif jawaban } & Frekuensi & Persentasi \\
\hline 1. & Selalu & 2 & $6 \%$ \\
2. & Sering & 3 & $10 \%$ \\
3. & Kadang-kadang & 3 & $10 \%$ \\
4. & Tidak pernah & 23 & $74 \%$ \\
5. & Jumlah & 31 & $100 \%$ \\
\hline
\end{tabular}

Berdasarkan tabel pernyataan indikator kesehatan siswa menunjukkan siswa yang memilih jawaban selalu adalah 2 orang atau sebesar 6\%. Jawaban sering dipilih oleh 3 orang atau sebesar 10\%. Jawaban kadang-kadang dipilih oleh 3 orang atau sebesar $10 \%$. Jawaban tidak pernah dipilih oleh 23 orang atau $74 \%$. Berdasarkan hasil tersebut dapat disimpulkan bahwa tanggapan siswa terhadap faktor-faktor yang mempengaruhi hasil belajar ansambel musik pada indikator kesehatan siswa berada pada kualifikasi "sangat baik". Sebab, presentase jawaban 
kadang-kadang dan tidak pernah dengan total $84 \%$ berada pada presentase $80 \%<$ sampai dengan $100 \%$. Sedangkan presentase jawaban selalu dan sering adalah $23 \%$. Berdasarkan data tersebut sudah sangat jelas apabila rata-rata siswa kelas VIII C dalam sehat daat mengikuti pembelajaran ansambel. Kecuali dua orang siswa yang ada gangguan penglihatan. Namun hal itu bisa diatasi dengan mengatur posisi duduk siswa yang mengalami gangguan penglihatan untuk duduk di tempat duduk yang paling depan sehingga peluang untuk tidak jelas dalam melihat penjelasan dari guru di depan kelas kecil. Pada saat proses pembelajaran ansambel gamelan jawa siswa yang mengalami gangguan penglihatan memilih alat musik yang jaraknya sangat dekat dengan papan tulis. Hasil ini dapat dilihat pada gambar dibawah ini :

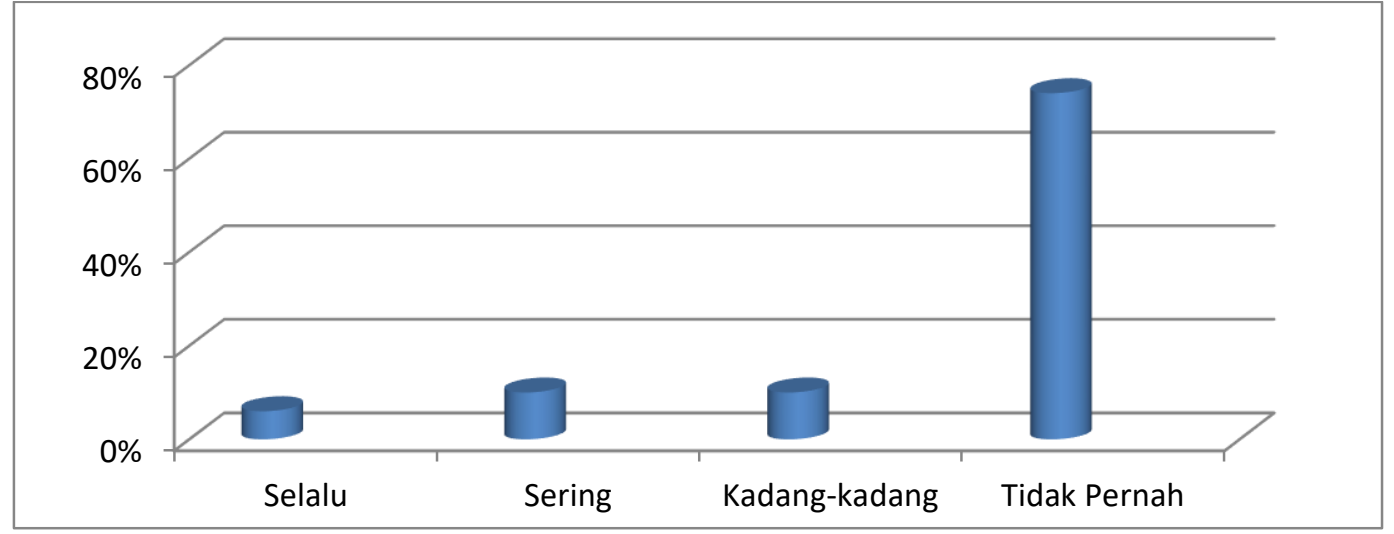

Gambar 4.15 Histogram Kesehatan Siswa

\subsubsection{Indikator Media Masa}

Indikator media masa terdapat pada butir soal ke 32 atas pernyataan "media dapat memberikan informasi yang berkaitan dengan pembelajaran seni musik" Hasil jawaban siswa dapat dilihat dalam tabel berikut. 
Tabel 4.20 Media Masa

\begin{tabular}{|c|l|c|c|}
\hline No & \multicolumn{1}{|c|}{ Alternatif jawaban } & Frekuensi & Persentasi \\
\hline 1. & Selalu & 10 & $32 \%$ \\
2. & Sering & 10 & $32 \%$ \\
3. & Kadang-kadang & 9 & $29 \%$ \\
4. & Tidak pernah & 2 & $7 \%$ \\
5. & Jumlah & 31 & $100 \%$ \\
\hline
\end{tabular}

Berdasarkan tabel pernyataan indikator media masa menunjukkan siswa yang memilih jawaban selalu adalah 10 orang atau sebesar $32 \%$. Jawaban sering dipilih oleh 10 orang atau sebesar 23\%. Jawaban kadang-kadang dipilih oleh 9 orang atau sebesar 29\%. Jawaban tidak pernah dipilih oleh 2 orang atau 7\%.Berdasarkan hasil tersebut dapat disimpulkan bahwa tanggapan siswa terhadap faktor-faktor yang mempengaruhi hasil belajar ansambel musik pada indikator media masa berada pada kualifikasi "baik". Sebab, presentase jawaban selalu dan sering dengan total $64 \%$ berada pada presentase $60 \%<$ sampai dengan 80\%. Sedangkan presentase jawaban kadang-kadang dan tidak pernah adalah $36 \%$.

Media masa memberikan pengaruh terhadap proses belajar siswa. Media masa yang memberikan pengetahuan-pengetahuan positif dapat mendukung proses belajar siswa. Media masa sekarang sudah sangat canggih dan marak di kalangan pelajar. Seperti misalkan adanya youtube yang sangat mudah diakses kapanpun dan dimanapun. Acara di televisi juga banyak yang menampilkan tentang berbagai kesenian musik atau kontes di bidang musik sehingga dapat membantu siswa dalam mengenal seni musik. Hasil ini dapat dilihat pada gambar dibawah ini : 


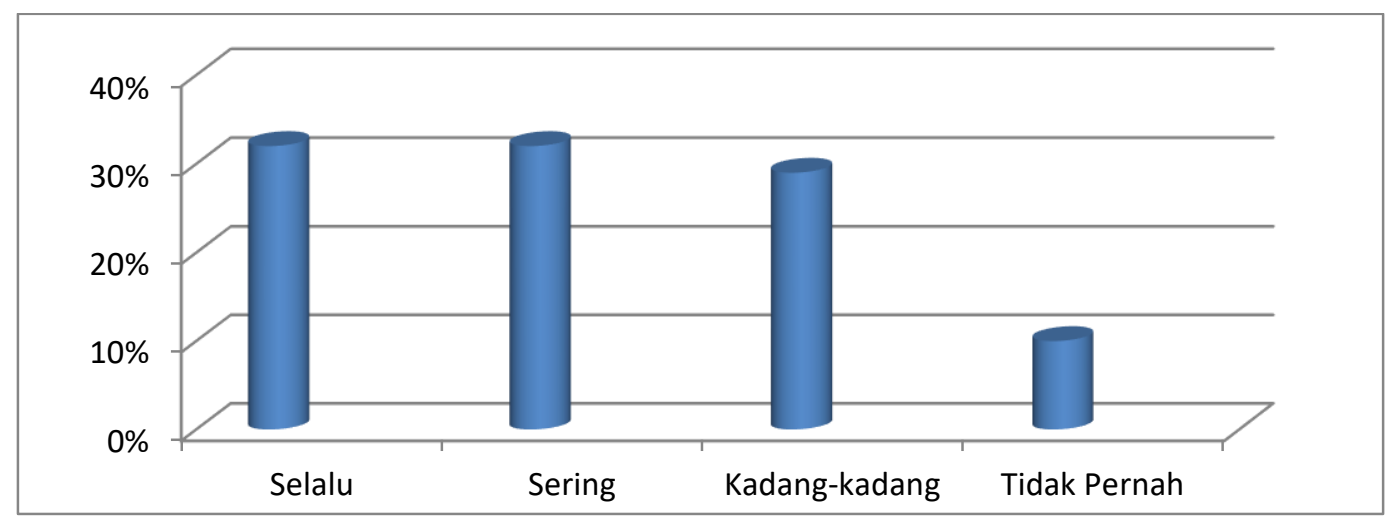

Gambar 4.16 Histogram Media Masa

\subsubsection{Indikator Bentuk Kehidupan Masyarakat}

Indikator bentuk kehidupan masyarakat terdapat pada butir soal ke 33 atas pernyataan "lingkungan memotivasi siswa untuk lebih giat belajar" Hasil jawaban siswa dapat dilihat dalam tabel berikut.

Tabel 4.21 Bentuk Kehidupan Masyarakat

\begin{tabular}{|c|l|c|c|}
\hline No & \multicolumn{1}{|c|}{ Alternatif jawaban } & Frekuensi & Persentasi \\
\hline 1. & Selalu & 17 & $54 \%$ \\
2. & Sering & 7 & $23 \%$ \\
3. & Kadang-kadang & 7 & $23 \%$ \\
4. & Tidak pernah & - & $0 \%$ \\
5. & Jumlah & 31 & $100 \%$ \\
\hline
\end{tabular}

Berdasarkan tabel pernyataan indikator bentuk kehidupan masyarakat menunjukkan siswa yang memilih jawaban selalu adalah 17 orang atau sebesar 54\%. Jawaban sering dipilih oleh 7 orang atau sebesar 23\%. Jawaban kadangkadang dipilih oleh 7 orang atau sebesar 23\%. Jawaban tidak pernah dipilih oleh 0 orang atau 0\%. Berdasarkan hasil tersebut dapat disimpulkan bahwa tanggapan siswa terhadap faktor-faktor yang mempengaruhi hasil belajar ansambel musik pada indikator bentuk kehidupan masyarakat berada pada kualifikasi "baik". 
Sebab, presentase jawaban selalu dan sering dengan total $77 \%$ berada pada presentase $60 \%$ < sampai dengan $80 \%$. Sedangkan presentase jawaban kadangkadang dan tidak pernah adalah $23 \%$.

Bentuk kehidupan masyarakat yang positif / lingkungan yang baik akan memberikan pengaruh yang baik terhadap siswa. Misal dalam sebuah lingkungan terdapat banyak orang berpendidikan dan senang terhadap belajar maka dapat memberi dampak positif terhadap belajar siswa. Siswa menjadi terdorong untuk belajar lebih giat lagi. Berbeda apabila lingkungan tersebut banyak orang yang tidak bersekolah, maka siswa akan bergaul dan ikut terbawa keadaan sehingga menjadi malas untuk belajar. Dari hasil diatas dapat diartikan bahwa lingkungan siswa rata-rata adalah lingkungan yang baik sehingga mendukung siswa dalam proses belajarnya di sekolah. Hasil ini dapat dilihat pada gambar dibawah ini :

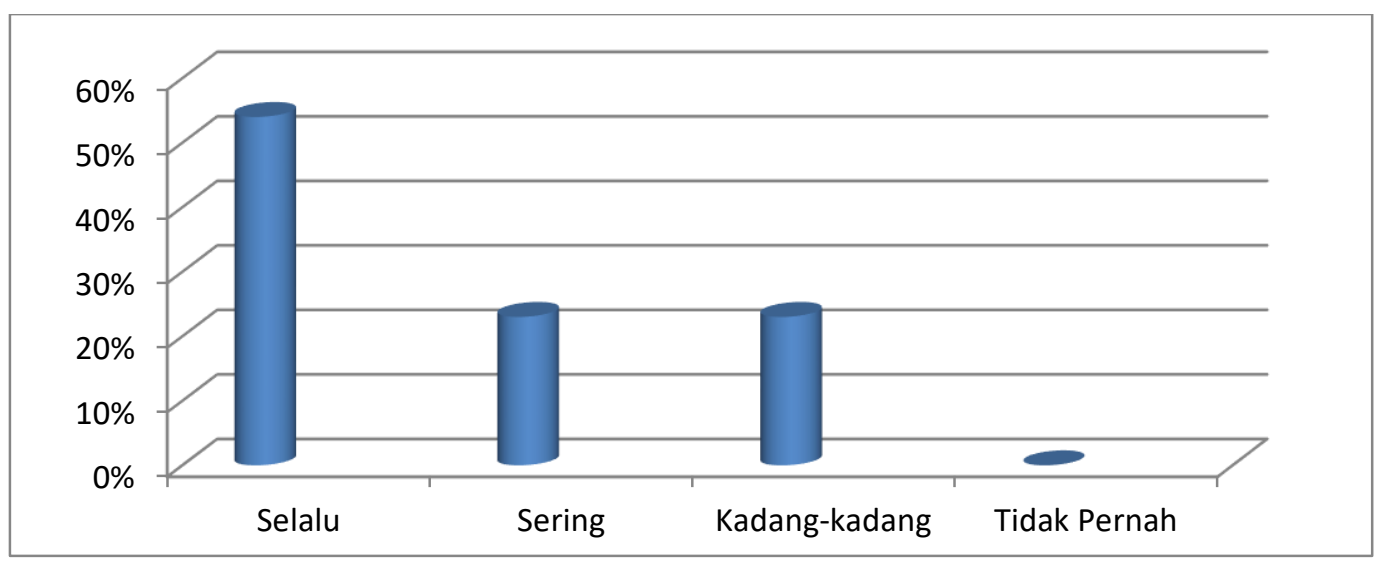

Gambar 4.17 Histogram Bentuk Kehidupan Masyarakat

\subsubsection{Indikator Cara Orang Tua Mendidik}

Indikator cara orang tua mendidik terdapat pada butir soal ke 6 atas pernyataan "orang tua memotivasi siswa ketika di rumah". Hasil jawaban siswa dapat dilihat dalam tabel berikut. 
Tabel 4.22 Cara Orang Tua Mendidik

\begin{tabular}{|c|l|c|c|}
\hline No & \multicolumn{1}{|c|}{ Alternatif Jawaban } & Frekuensi & Persentasi \\
\hline 1. & Selalu & 25 & $81 \%$ \\
2. & Sering & 4 & $13 \%$ \\
3. & Kadang-kadang & 2 & $6 \%$ \\
4. & Tidak pernah & - & $0 \%$ \\
5. & Jumlah & 31 & $100 \%$ \\
\hline
\end{tabular}

Berdasarkan tabel pernyataan indikator cara orang tua mendidik menunjukkan siswa yang memilih jawaban selalu adalah 25 orang atau sebesar $81 \%$. Jawaban sering dipilih oleh 4 orang atau sebesar $13 \%$. Jawaban kadangkadang dipilih oleh 2 orang atau sebesar $6 \%$. Jawaban tidak pernah dipilih oleh 0 orang atau 0\%. Berdasarkan hasil tersebut dapat disimpulkan bahwa tanggapan siswa terhadap faktor-faktor yang mempengaruhi hasil belajar ansambel musik pada indikator cara orang tua mendidik berada pada kualifikasi "sangat baik". Sebab, presentase jawaban selalu dan sering dengan total $94 \%$ berada pada presentase $80 \%$ < sampai dengan $100 \%$. Sedangkan presentase jawaban kadangkadang dan tidak pernah adalah 6\%. Dari hasil tersebut dapat disimpulkan bahwa didikan dari orang tua kepada siswa kelas VIII C rata-rata sangat mendukung proses belajar siswa. (Suharto \& Indriyanto, 2018).

Mendidik akan lebih baik jika dilakukan dari hati. Mendidik hendaknya dilakukan sesuai dengan pengetahuan mendidik yang baik. Sebab, pendidikan pertama bagi seorang anak adalah dari lingkungan keluarganya. Seringnya interaksi anak dengan keluarga akan mempengaruhi cara siswa belajar di sekolah. Untuk itu, orang tua hendaknya memberikan didikan yang terbaik untuk anaknya yang akan menghantarkan anaknya dalam keberhasilan belajar. Motivasi dari orang tua sangat dibutuhkan bagi siswa. Karena orang tua adalah orang yang 
paling dekat dengan anaknya dan paling mengerti bagaimana perkembangan ankanya. Sehingga motivasi yang diberikan untuk kemajuan siswa dalam belajar sangatlah dibutuhkan agar siswa dapat berkembang dengan baik dalam proses belajarnya sehingga tujuan pembelajaran dapat tercapai. Hasil ini dapat dilihat pada gambar dibawah ini:

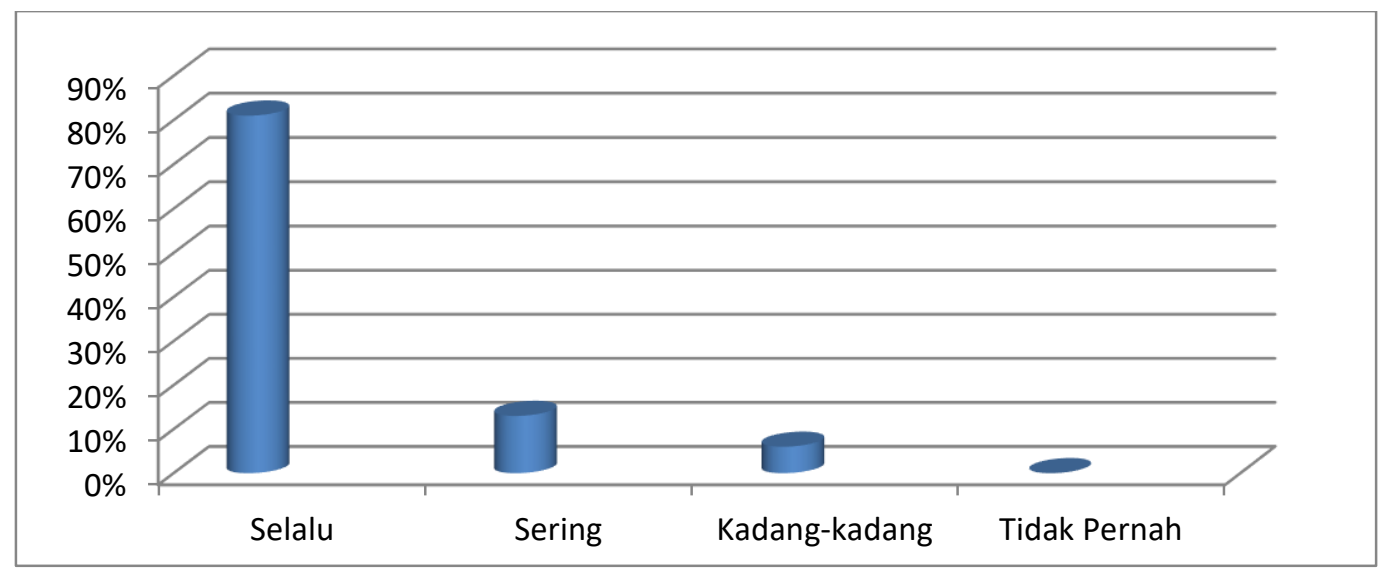

Gambar 4.18 Histogram Cara Orang Tua Mendidik

\subsubsection{Indikator Pengertian Orang Tua}

Indikator pengertian orang tua terdapat pada butir soal ke 7 atas pernyataan "orang tua memantau kegiatan belajar siswa di rumah" Hasil jawaban siswa dapat dilihat dalam tabel berikut.

Tabel 4.23 Pengertian Orang Tua

\begin{tabular}{|c|l|c|c|}
\hline No & \multicolumn{1}{|c|}{ Alternatif jawaban } & Frekuensi & Persentasi \\
\hline 1. & Selalu & 18 & $58 \%$ \\
2. & Sering & 8 & $26 \%$ \\
3. & Kadang-kadang & 5 & $16 \%$ \\
4. & Tidak pernah & - & $0 \%$ \\
5. & Jumlah & 31 & $100 \%$ \\
\hline
\end{tabular}

Berdasarkan tabel pernyataan indikator pengertian orang tua menunjukkan siswa yang memilih jawaban selalu adalah 18 orang atau sebesar $58 \%$. Jawaban 
sering dipilih oleh 8 orang atau sebesar 26\%. Jawaban kadang-kadang dipilih oleh 2 orang atau sebesar $6 \%$. Jawaban tidak pernah dipilih oleh 0 orang atau $0 \%$. Berdasarkan hasil tersebut dapat disimpulkan bahwa tanggapan siswa terhadap faktor-faktor yang mempengaruhi hasil belajar ansambel musik pada indikator pengertian orang tua berada pada kualifikasi "sangat baik". Sebab, presentase jawaban selalu dan sering dengan total $84 \%$ berada pada presentase $80 \%$ < sampai dengan $100 \%$. Sedangkan presentase jawaban kadang-kadang dan tidak pernah adalah $16 \%$.

Dukungan orang tua terhadap proses belajar anak sangat dibutuhkan, apalagi untuk mencapai keberhasilan belajar anaknya. Peran orang tua adalah mengantarkan anaknya agar bisa sukses dalam belajarnya sehingga harapan untuk menjadikan anak sebagai anak yang bermanfaat bagi dirinya sendiri, orang tua, dan masyarakat dapat terwujud. Dari hasil tersebut terlihat bahwa orang tua sangat mendukung siswa dalam keberhasilan belajar siswa. Hasil ini dapat dilihat pada gambar dibawah ini :

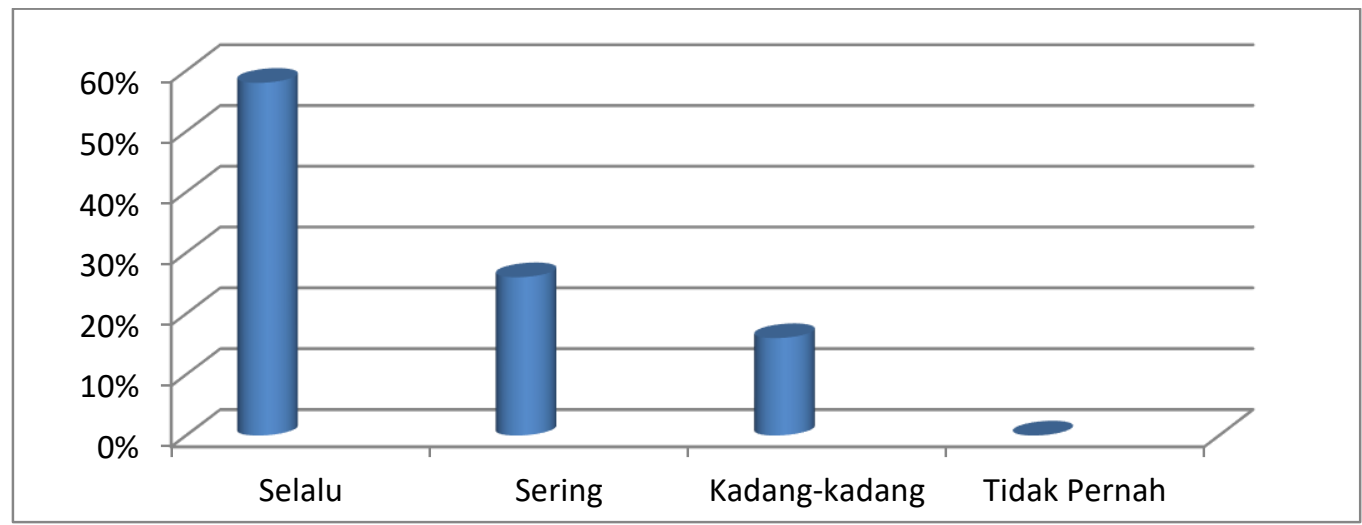

Gambar 4.19 Histogram Pengertian Orang Tua 


\subsubsection{Indikator Keadaan Ekonomi Keluarga}

Indikator keadaan ekonomi keluarga terdapat pada butir soal ke 23 atas pernyataan "orang tua memberikan sarana dan prasarana yang dibutuhkan untuk belajar di rumah" Hasil jawaban siswa dapat dilihat dalam tabel berikut.

Tabel 4.24 Keadaan Ekonomi Keluarga

\begin{tabular}{|c|l|c|c|}
\hline No & \multicolumn{1}{|c|}{ Alternatif jawaban } & Frekuensi & Persentasi \\
\hline 1. & Selalu & 14 & $45 \%$ \\
2. & Sering & 9 & $29 \%$ \\
3. & Kadang-kadang & 7 & $23 \%$ \\
4. & Tidak pernah & 1 & $3 \%$ \\
5. & Jumlah & 31 & $100 \%$ \\
\hline
\end{tabular}

Berdasarkan tabel pernyataan indikator keadaan ekonomi keluarga menunjukkan siswa yang memilih jawaban selalu adalah 14 orang atau sebesar 45\%. Jawaban sering dipilih oleh 9 orang atau sebesar 29\%. Jawaban kadangkadang dipilih oleh 7 orang atau sebesar 23\%. Jawaban tidak pernah dipilih oleh 1 orang atau 3\%. Berdasarkan hasil tersebut dapat disimpulkan bahwa tanggapan siswa terhadap faktor-faktor yang mempengaruhi hasil belajar ansambel musik pada indikator keadaan ekonomi keluarga berada pada kualifikasi “baik”. Sebab, presentase jawaban selalu dan sering dengan total $74 \%$ berada pada presentase $60 \%$ < sampai dengan $80 \%$. Sedangkan presentase jawaban kadang-kadang dan tidak pernah adalah $26 \%$.

Keadaan ekonomi keluarga berpengaruh terhadap kemajuan belajar siswa. Keadaan ekonomi yang kurang stabil akan menghambat kemajuan belajar siswa. Begitu juga apabila siswa terlahir dari keluarga yang kaya raya ada kemungkinan orang tua tidak tahan melihat anaknya belajar dengan bersusah payah sehingga kemajuan belajar anak terhambat (Slameto, 2010:64). Dari hasil tersebut dapat 
disimpulkan bahwa artinya orang tua memberikan dukungan materi secara penuh kepada siswa untuk keberhasilan belajarnya. Hasil ini menandakan bahwa ratarata dukungan orang tua siswa kelas VIII C terhadap keberhasilan siswa kelas VIII C dalam belajarnya sudah baik. Hasil ini dapat dilihat pada gambar dibawah ini :

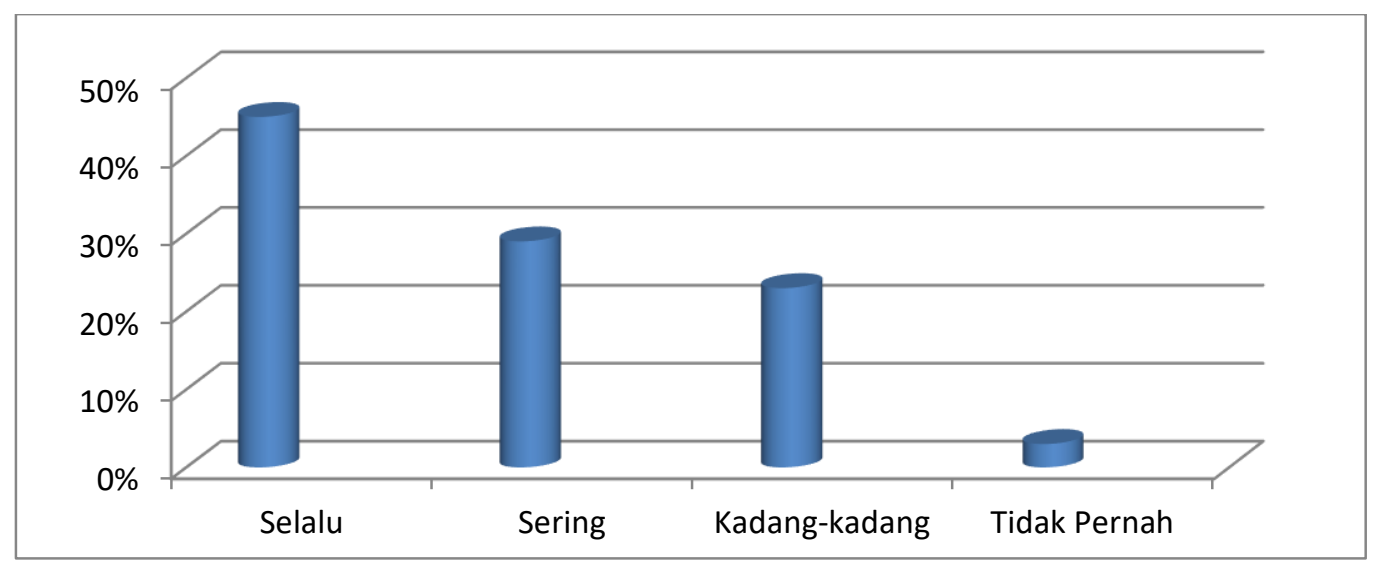

Gambar 4.20 Histogram Keadaan Ekonomi Keluarga

Dari hasil di atas dapat disimpulkan bahwa tanggapan siswa kelas VIII C SMPN 22 Semarang terhadap faktor-faktor yang mempengaruhi hasil belajar ansambel musik menghasilkan dua macam tanggapan yaitu tanggapan positif dan tanggapan negatif. Indikator dari faktor-faktor yang mendapat tanggapan positif dari siswa kelas VIII C SMPN 22 Semarang diantaranya yaitu perhatian guru terhadap siswa, hubungan guru dengan siswa, bakat siswa, minat siswa, perhatian siswa, disiplin sekolah, media masa, bentuk kehidupan masyarakat, keadaan ekonomi keluarga, standar kurikulum, alat pelajaran, kesehatan siswa, cara orang tua mendidik, dan pengertian orang tua. Sedangkan indikator faktor-faktor yang mendapat tanggapan negatif dari siswa diantaranya yaitu perhatian guru dalam 
memberikan tugas, keadaan gedung, minat siswa, motivasi siswa dan standar pelajaran di atas ukuran. 


\section{BAB V \\ PENUTUP}

\subsection{Simpulan}

Pembelajaran ansambel di SMPN 22 Semarang dilaksanakan di dalam ruang gamelan jawa dengan alur pembelajaran mulai dari tahap perencanaan, pelaksanaan dan tahap evaluasi. Pada tahap perencanaan guru merencanakan pembelajaran berdasarkan kompetensi yang harus dicapai dalam bentuk rencana pelaksanaan pembelajaran (RPP). Pada tahap pelaksanaan guru melaksanakan pembelajaran di kelas dengan melakukan kegiatan pendahuluan, kegiatna inti dan kegiatan penutup. Sedangkan pada tahap evaluasi guru mengadakan evaluasi dalam bentuk tes unjuk kerja.

Siswa kelas VIII C SMPN 22 Semarang menanggapi faktor-faktor yang mempengaruhi hasil belajar ansambel secara positif dan negatif. Indikator dari faktor-faktor yang mendapat tanggapan positif diantaranya yaitu perhatian guru terhadap siswa, hubungan guru dengan siswa, bakat siswa, minat siswa, perhatian siswa, disiplin sekolah, media masa, bentuk kehidupan masyarakat, keadaan ekonomi keluarga, standar kurikulum, alat pelajaran, kesehatan siswa, cara orang tua mendidik, dan pengertian orang tua. Sedangkan indikator faktor-faktor yang mendapat tanggapan negatif dari siswa diantaranya yaitu perhatian guru dalam memberikan tugas, keadaan gedung, minat siswa, motivasi siswa dan standar pelajaran di atas ukuran. 


\subsection{Saran}

Berdasarkan hasil observasi, maupun wawancara, saran peneliti terhadap guru, maupun sekolah yaitu sebagai berikut :

5.2.1 Bagi sekolah hendaknya dapat membangun ruang musik yang kedap suara agar pembelajaran seni musik tidak mengganggu pelajaran. Sekolah hendaknya juga merawat alat musik yang sudah ada di sekolah agar tidak mudah rusak.

5.2.2 Bagi guru seni musik kelas VIII SMPN 22 Semarang hendaknya melaksanakan pembelajaran sesuai dengan perencanaan yang telah dibuat sehingga tujuan yang telah diumuskan dapat tercapai dengan baik.

5.2.3 Dukungan sekolah terhadap ansambel gamelan jawa di sekolah harus lebih diseriuskan lagi terutama untuk perhatian sekolah terhadap keberadaan ekstrakurikuler gamelan jawa di sekolah. Sebab, apabila ekstrakuler gamelan jawa mendapat dukungan dan perhatian maka keberadaanya akan menjadi lebih maju dan anak-anak yang mempunyai potensi di bidang seni musik akan lebih dioptimalkan lagi kemampuanya melalui ekstrakurikuler gamelan jawa di sekolah. 


\section{DAFTAR PUSTAKA}

Ali, Muhammad. 2007. Guru dalam Proses Belajar Mengajar. Bandung:Sinar Baru Algensindo.

Ambarjaya Beni S. 2012. Psikologi Pendidikan dan Pengajaran. Yogyakarta: Caps.

Aunurrahman. 2012. Belajar dan Pembelajaran. Bandung: Alfabeta.

Dalyono. 2007. Psikologi Pendidikan. Jakarta: Rineka Cipta.

Danang, Nicodemus. 2011. Pembelajaran Seni Musik Pada Siswa Kelas VIIA SMPN 9 Semarang Kajian Tentang Strategi Penggunaan Metode dan Media Cerita Pendek. Skripsi. Sendratasik Unnes.

Daryanto. 2013. Media Pembelajaran. Yogyakarta: Gava Media.

Departemen Pendidikan Nasional. 2010. Kamus Besar Bahasa Indonesia. Jakarta: PT. Gramedia Pustaka Utama.

Diyan, Y. Kurniawati. 2007. Pembelajaran Ansambel Musik di SMPN 22 Semarang. Skripsi. Sendratasik Unnes.

Emzir. 2010. Metodologi Penelitian Pendidikan: Kuantitatif dan Kualitatif. Jakarta: Rajawali Pers.

Febriyanto, A.W. 2011. Pembelajaran Anasambel Musik di Kelas VIII Pada SMPN 1 Pangkah Tegal. Skripsi. Sendratasik Unnes.

Fitriyati. 2016. Keefektifan Teknik Membaca DRTA dan Teknik Membaca PORPE (Predict, organize, rehearse, practice, evaluate) terhadap Pembelajaran Menangkap Makna Teks Ekplanasi Kelas VII SMP. Skripsi. Pendidikan Bahasa dan Sastra Indonesia Unnes.

Hartono. Tanpa Tahun. "Perkembangan Estetika Musikal Seni Karawitan Jawa dan Pengaruhnya Terhadap Masyarakat Pendukungnya". Skripsi. Seni dan Desain UNM.

Khamim, Muchammad F.N. 2011. Pembelajaran Ekstrakurikuler Rebana Terbang Zipin di Madrasah Aliyah Negeri 01 Kabupaten Kudus. Skripsi. Sendratasik Unnes.

Kustiono. 2013. Teori Belajar dan Implementasinya dalam Pembelajaran. Yogyakarta;Deepublish. 
Lutfiyah, Ufi. 2014. Faktor-faktor yang Memengaruhi Motivasi Belajar IPS Siswa Kelas Kelas V di SDIT Insan Mulia Tanggerang Selatan. Skripsi. Jakarta. PGMI UIN Syarif Hidayatullah.

Margono. 2010. Metodologi Penelitian Pendidikan. Jakarta: Rineka Cipta.

Mustaqim. 2008. Psikologi pendidikan. Yogyakarta: Pustaka Pelajar

Nur, Shela. 2015. Bentuk dan Fungsi Pertunjukkan Angklung "Gelas Cantel” di Desa Karangsari Kecamatan Pulosari Kabupaten Pemalang. Skripsi. Sendratasik Unnes.

Priyandaru, N.D.W. 2011. Pembelajaran Seni Musik Pada Siswa Kelas VII A SMPN 22 Bantuk. Skripsi. Sendratasik Unnes.

Purwanto. 2014. Evaluasi Hasil Belajar. Yogyakarta; Pustaka Pelajar.

Siregar, Eveline dan Hartini, Nara. 2010. Teori Belajar dan Pembelajaran.Bogor: Ghalia Indonesia.

Rachman, Abdul. 2016. Penggunaan Media Bcking Track Pada Pembelajaran Mata Kuliah Keroncong di Jurusan Sendratasik Universitas Negeri Semarang. Harmonia. Semarang: Jurusan Sendratasik UNNES.

Rifai, Achmad dan Catharina, Tri Anni. 2009. Psikologi Pendidikan. Semarang; Universitas Negeri Semarang Press.

Semarang; Universitas Negeri Semarang Press.

Semarang; Universitas Negeri Semarang Press.

2011. Psikologi Pendidikan.

Slameto. 2010. Belajar dan Faktor-faktor yang Memengaruhi. Jakarta;Rineka Cipta.

Sudjana, Nana. 2009. Dasar-dasar Proses Belajar Mengajar. Bandung: Sinar Baru Algensindo.

Rosdakarya.

Sugiyono. 2014. Memahami Penelitian Kualitatif. Bandung: Alfabeta 
Suharto. 2007. Pengembangan Materi dan Kegiatan Pembelajaranya dalam Kurikulum Tingkat Satuan Pendidikan Bidang Seni Musik. Harmonia. Semarang: Jurusan Sendratasik UNNES

Suharto, \& Indriyanto. (2018). Preserving Calung Banyumasan through Vocational Education and its Community. IOP Conference Series: Materials Science and Engineering, 306, 12120. https://doi.org/10.1088/1757899X/306/1/012120

Suharto, Sumaryanto, T., \& Ganap, V. (2017). Banyumasan Songs As Banyumas People's Character Reflection. HARMONIA : Journal of Arts Research and Education, 17(1), 49-56. https://doi.org/10.15294/harmonia.v17i1.6460

Sukmadinata, Nana Syaodih. 2013. Metode Penelitian Pendidikan. Bandung: PT Remaja Rosdakarya.

Syah, Muhibbin. 2009. Psikologi Belajar. Jakarta: Rajawali Pers. 2009. Psikologi Pendidikan. Bandung:Remaja Rosdakarya.

Waluyojati, Wahyu. 2013. Pembeljaran Ekstrakurikuler Hardrochestra di SMAN 1 Kebumen Kabupaten Kebumen. Skripsi. Sendratasik Unnes.

Willis, Sofyan S. 2012. Psikologi Pendidikan. Bandung: Alfabeta.

Santrock, John w. 2008. Psikologi Pendidikan. Jakarta: Kencana Prenada Media Group.

Suardi, Moh. 2012. Pengantar Pendidikan Teori dan Aplikasi. Jakarta: Indeks.

Sunardi. Meningkatkan Hasil Beajar Bermain Musik Ansambel Melalui Metode Tutor Sebaya Kelas VIII D SMPN 14 Purworejo Tahun Pelajaran 2012/2013. Skripsi. Sendratasik Unnes.

Undang-undang No. 20 Tahun 2003 tentang Sikdiknas.

Utomo, Udi dan Sinaga, S.S. 2009. Pengembangan Materi Pembelajaran Seni Musik Berbasis Seni Budaya Berkonteks Kreatif, Kecakapan Hidup, dan Menyenangkan Bagi Siswa SD/MI. Harmonia. Semarang: Jurusan Sendratasik UNNES.

Yudha, S. Afrizal. 2015. Strategi Pembelajaran Ansambel Musik Pada Kegiatan Ekstrakurikuler di SMPN 2 Bantul. Skripsi. Seni Musik UNY.

Diunduh tanggal 5 November 2017 pada laman, 
https://www.kompasiana.com/www.eman.com/hilangnya-budayaindonesia_54f3621d745513972b6c734d

Diunduh tanggal 5 November 2017 pada laman, https://aldysatria186.wordpress.com/2015/01/31/pentingnya-pengenalanbudaya-jawa-kepada-penerus-bangsa/

Diunduh tanggal 5 November 2017 pada laman, http://bse.kemendikbud.go.id

Lampiran 1

\section{RENCANA PELAKSANAAN PEMBELAJARAN}

(RPP)

\section{Sekolah \\ Kelas \\ Mata Pelajaran \\ Semester \\ Alokasi Waktu \\ Standar Kompetensi \\ Kompetensi Dasar}

\section{A. Tujuan Pembelajaran}

Pada akhir pembelajaran siswa dapat :

1. Membentuk susunan panitia pagelaran

2. Menyajikan lagu etnik nusantara sesuai pilihan kelompok

3. Berlatih memainkan lagu nusantara dengan alat musik melodis secara kelompok.

* Karakter Siswa yang diharapkan :

B. Materi Pembelajaran

Disiplin (Discipline )

Tekun (diligence)

Tanggung jawab (responsibility)

Ketelitian (carefulness)

Kerja sama (cooperation)

Percaya diri (confidence)

Kecintaan (lovely)
a. Kreasi Musik Nusantara
b. Pergelaran Kelas

\section{Metode Pembelajaran}

Metode pendekatan CTL dan Lifeskill 


\section{Langkah-langkah Pembelajaran}

\section{Pertemuan pertama dan kedua}

a. Kegiatan Pendahuluan

Tanya jawab berbagai hal terkait dengan wawasan siswa mengenai materi yang akan disajikan.

b. Kegiatan Inti

- Eksplorasi

Dalam kegiatan eksplorasi, guru :

- Membuat perencanaan pagelaran

- Menyanyikan lagu etnik nusantara sesuai pilihan dalam kelompoknya

- Memfasilitasi peserta didik melakukan percobaan di studio, atau lapangan.

\section{- Elaborasi}

Dalam kegiatan elaborasi, guru:

- Berlatih secara kelompok lagu pilihan dengan alat musik melodis

- Menuliskan hasil aransemen sederhana lagu pilihan dalam kelompok

- Memfasilitasi peserta didik melakukan pameran, turnamen, festival, serta produk yang dihasilkan;

\section{- Konfirmasi}

Dalam kegiatan konfirmasi, guru:

- Memberikan umpan balik positif dan penguatan dalam bentuk lisan, tulisan, isyarat, maupunn hadiah terhadap keberhasilan peserta didik,

- Memberikan konfirmasi terhadap hasil eksplorasi dan elaborasi peserta didik melalui berbagai sumber,

- Memfasilitasi peserta didik melakukan refleksi untuk memperoleh pengalaman belajar yang telah dilakukan,

- Memfasilitasi peserta didik untuk memperoleh pengalaman yang bermakna dalam mencapai kompetensi dasar:

- Berfungsi sebagai narasumber dan fasilitator dalam menjawab pertanyaan peserta didik yang menghadapi kesulitan, dengan menggunakan bahasa yang baku dan benar;

- Membantu menyelesaikan masalah

- Memberi acuan agar peserta didik dapat melakukan pengecekan hasil eksplorasi;

- Memberi informasi untuk bereksplorasi lebih jauh;

- Emberi motivasi kepada peserta didik yang kurang atau belum berpartisipasi aktif.

c. Kegiatan Penutup 
Dalam kegiatan penutup, guru:

- Menanyakan kesulitan siswa selama PBM

- Menugaskan untuk berlatih memainkan hasil aransemen secara kelompok.

\section{E. Alat/Sumber Belajar}

Buku "Seni Budaya.

Casette/DVD/guru

Recorder sopran, pianika, gitar akustik

\section{F. Penilaian}

Penilaian dilaksanakan selama proses dan sesudah pembelajaran

\begin{tabular}{|c|c|c|c|c|}
\hline \multirow[b]{2}{*}{$\begin{array}{c}\text { Indikator Pencapaian } \\
\text { kompetensi }\end{array}$} & \multicolumn{4}{|c|}{ Penilaian } \\
\hline & Teknik & $\begin{array}{c}\text { Bentuk } \\
\text { Instrumen }\end{array}$ & & Contoh Instrumen \\
\hline $\begin{array}{l}\text { Mampu membuat } \\
\text { perencanaan } \\
\text { pementasan di } \\
\text { dalam kelas dengan } \\
\text { uraian tugas yang } \\
\text { tepat } \\
\text { * Memainkan hasil } \\
\text { aransemen }\end{array}$ & $\begin{array}{l}\text { Tes } \\
\text { praktik/k } \\
\text { inerja }\end{array}$ & $\begin{array}{c}\text { Tes Uji } \\
\text { Petik } \\
\text { kinerja }\end{array}$ & $\star$ & $\begin{array}{l}\text { Buatlah perencanaan } \\
\text { pementasan seni di } \\
\text { sekolah } \\
\text { Mainkanlah hasil } \\
\text { aransemen yang telah } \\
\text { kalian buat } \\
\text { Bentuklah sususan } \\
\text { panitia pagelaran! } \\
\text { Nyanyikanlah lagu } \\
\text { nusantara pilihan } \\
\text { bersama dalam } \\
\text { kelompok kalian! } \\
\text { Buatlah aransemen } \\
\text { sederhana untuk lagu } \\
\text { pilihan tersebut! } \\
\text { Berlatihlah memainkan } \\
\text { melodi lagu tersebut } \\
\text { dengan menggunakan } \\
\text { alat musik melodis }\end{array}$ \\
\hline
\end{tabular}

Format Penilaian

\begin{tabular}{|c|l|c|c|c|c|c|}
\hline \multirow{2}{*}{ No } & \multirow{2}{*}{ Aspek-aspek yang dinilai } & \multicolumn{5}{c|}{ Penilaian } \\
\cline { 3 - 7 } & & 1 & 2 & 3 & 4 & 5 \\
\hline 1 & Kepanitiaan & & & & & \\
\hline 2 & Kekompakan kelompok & & & & & \\
\hline 3 & Kreativitas aransemen & & & & & \\
\hline 4 & Kedisiplinan dalam berlatih & & & & & \\
\hline
\end{tabular}


\begin{tabular}{|l|l|}
\hline & Jumlah \\
\hline
\end{tabular}

Keterangan ceklis pada angka

1 = sangat baik

2 = kurang

3 = cukup

4 =baik

5 =sangat baik

Mengetahui,

Kepala SMPN 22 Semarang

Drs. Sawukir, M.Pd.

NIP.196612121994121004
Semarang, 6 Januari 2017

Guru Mapel SBK

Kasih, S.Pd.

NIP. 196008021964031011 
Lampiran 2

\section{PEDOMAN WAWANCARA}

1. Wawancara dengan kepala sekolah

a. Siapa nama bapak ?

b. Bagaimana pelaksanaan kurikulum secara umum yang digunakan di SMPN 22 Semarang ?

c. Kebijaksanaan apa yang diterapkan terhadap mata pelajaran seni musik sehubungan dengan peraturan kurikulum yang dipakai ?

d. Apa pendapat $\mathrm{Bp} / \mathrm{Ibu}$ tentang mata pelajaran seni musik dilihat dari potensi yang ada di sekolah tersebut baik dari siswa, guru, atau semua yang tersedia?

e. Bagaimana dukungan sekolah terhadap pelajaran seni musik di SMPN 22 Seamarang?

2. Wawancara dengan guru mata pelajaran seni musik

a. Siapa nama Bapak ?

b. Apakah latar belakang pendidikan Bapak ?

c. Sudah berapa lama menjadi guru seni musik di SMPN 22 Semarang ?

d. Bagaimana pengalaman Bapak dalam mengajar seni musik ?

e. Bagaimana persiapan mengajar materi ansambel ?

f. Metode apa saja yang digunakan dalam mengajar ansambel ?

3. Wawancara dengan Kepala Tata Usaha (TU) SMPN 22 Semarang

a. Bagaimana letak geografis SMPN 22 Semarang ?

b. Bagaimana sejarah berdirinya SMPN 22 Semarang ?

c. Bagaimana kondisi fisik SMPN 22 Semarang? 
d. Berapa jumlah ruang yang ada di SMPN 22 Semarang ?

e. Berapa jumlah guru dan karyawan di SMPN 22 Semarang ?

f. Berapa jumlah siswa dan siswi di SMPN 22 Semarang?

g. Sarana dan prasarana pendidikan apa saja yang dimiliki SMPN 22 Semarang?

h. Alat musik apa saja yang dimiliki oleh SMPN 22 Semarang ?

4. Wawancara dengan siswa

a. Bagaimana pendapat anda terhadap cara mengajar guru dalam mengajar ansambel?

b. Apakah anda senang dengan materi pembelajaran ansambel yang diberikan oleh guru seni musik ?

c. Bagaimana pendapat anda tentang cara penilaian yang diberikan guru seni musik dalam pelajaran anasmabel ?

d. Prestasi apakah yang anda harapkan dari hasil kegiatan belajar mengajar ansambel ?

e. Pernahkah sekolah sekolah mengirim tim untuk mengikuti pentas seni musik ? apakah anda termasuk angggota di dalam tim itu ?

f. Hambatan apa saja yang dihadapi dalam mengikuti pelajaran seni musik materi ansambel ? 
Lampiran 3

\section{PEDOMAN OBSERVASI}

Peneliti akan melakukan observasi dengan tujuan untuk mengetahui bagaimana lingkungan fisik sekolah, kurikulum yang digunakan, perencanaan pembelajaran, proses pembelajaran, evaluasi pembelajaran, sarana dan prasarana penunjang pembelajaran seni musik di sekolah, alokasi waktu pembelajaran seni musik setiap pekan, jam per minggu pertemuan, dan bukti fisik tentang eksistensi belajar seni musik di SMPN 22 Semarang. 
Lampiran 4

\section{PEDOMAN DOKUMENTASI}

Dokumentasi dalam skripsi "Pembelajaran Ansambel Musik di Kelas VIII C SMPN 22 Semarang"adalah sebagai berikut:

1. Data-data yang didapat dari lokasi penelitian.

2. Foto sarana dan prasarana pembelajaran.

3. Foto proses pembelajaran Ansambel Musik.

4. Foto proses penilaian pembelajaran Ansambel Musik. 
Lampiran 5

\section{NOTASI GAMELAN LAGU SUWE ORA JAMU \\ Suwe Ora Jamu}

PI : 6

$$
\begin{aligned}
& \mathrm{BK}=-3-5-6-5-3-2-6 / 6-6 / 6 \bigcirc \\
& +\quad+\mathrm{N}+\mathrm{P}+\mathrm{N}+\mathrm{P}+\mathrm{N}+\mathrm{P}+\mathrm{N} \\
& \text { A. }-1-3-1-3-1-2-3- \\
& +\quad+\mathrm{N}+\mathrm{P}+\mathrm{N}+\mathrm{P}+\mathrm{N}+\mathrm{P}+\mathrm{N} \\
& -3-5-6-5-4-2-1 \\
& \text { Ket }=+\quad: \quad \text { Kethuk } \\
& \mathrm{N} \quad \text { : Kenong } \\
& \text { P : Kempul } \\
& \text { : : Gong }
\end{aligned}
$$

\section{Notasi Kendang}

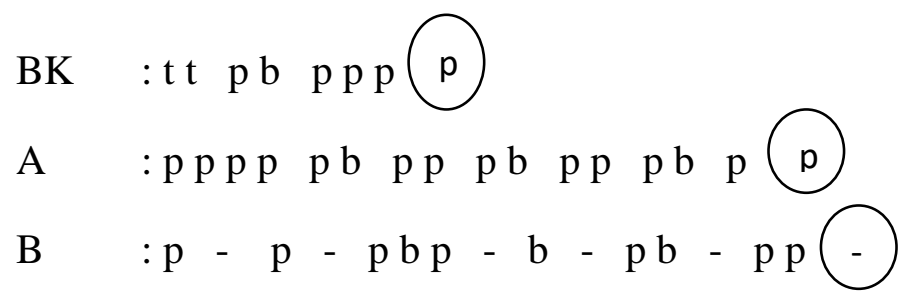




$$
\begin{aligned}
& \text { Ket }=\mathrm{t} \quad: \quad \text { tak } \\
& \text { P : : pung } \\
& \text { b : bem }
\end{aligned}
$$

\section{Lampiran 6 Foto Penelitian}

Gambar Lokasi dan Kegiatan Penelitian

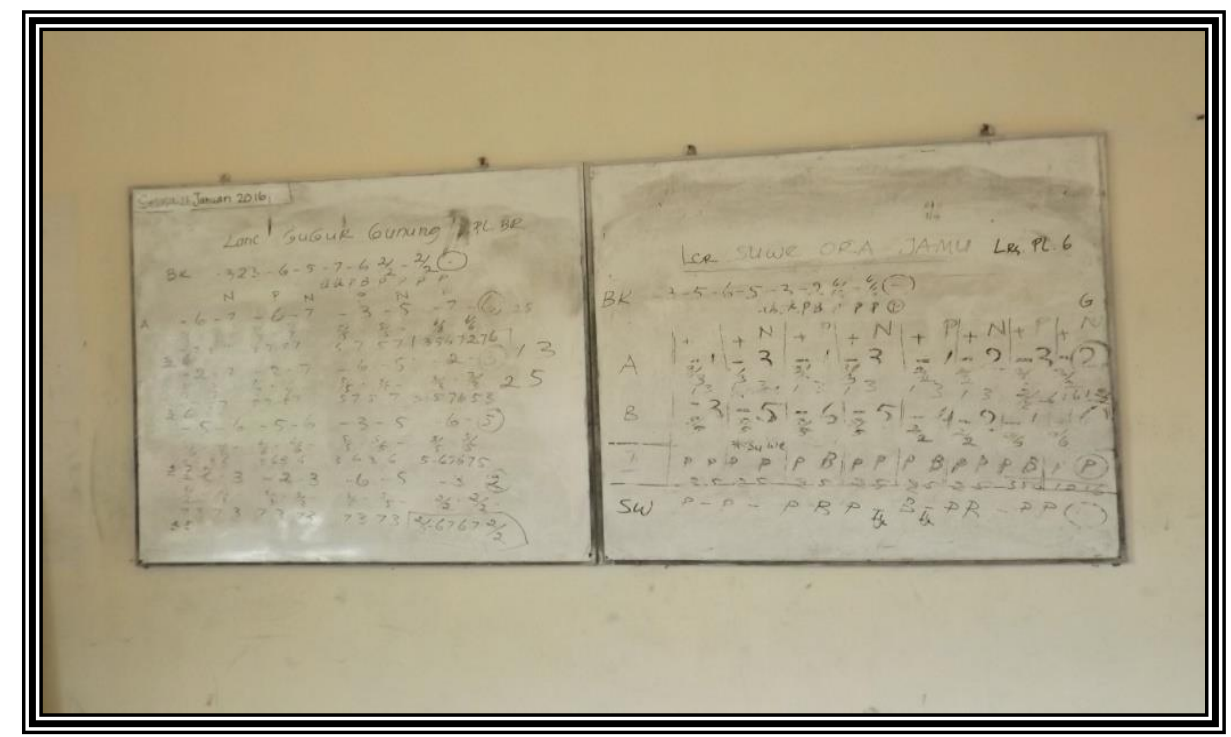

Gambar 5.21 Notasi Gamelan Jawa ditulis di Papan Tulis Ruang Gamelan Jawa

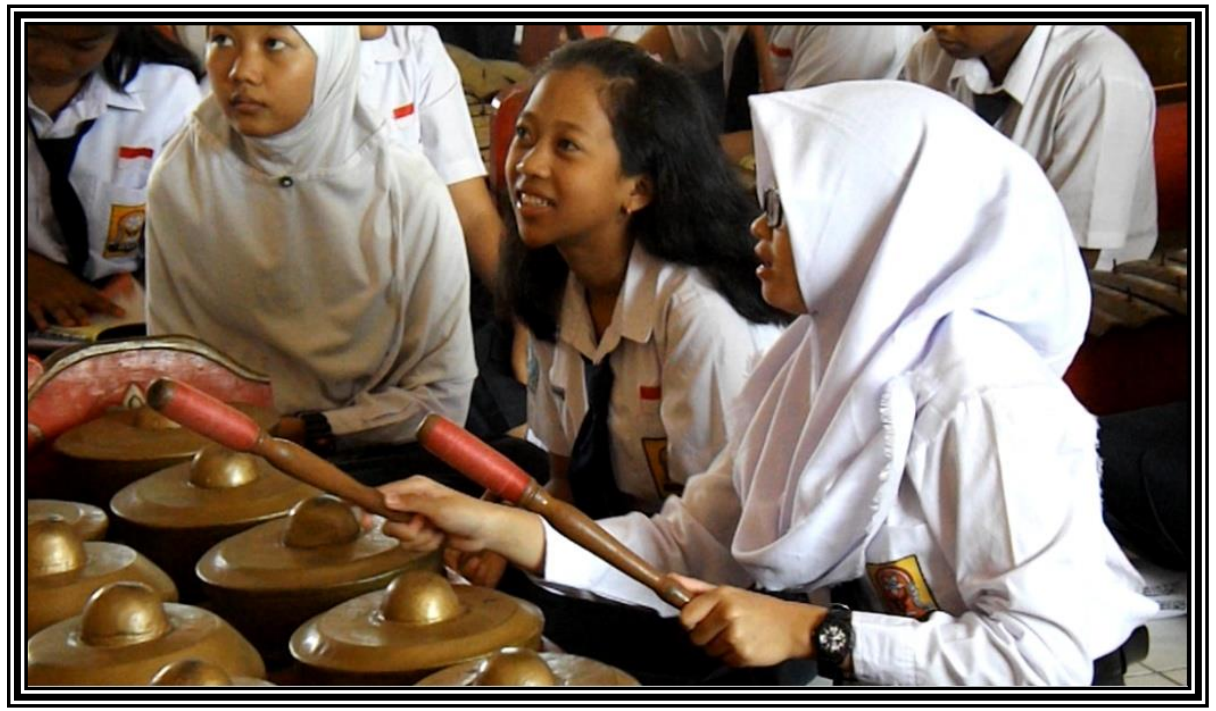


Gambar 5.22 Siswa Saat Mengikuti Proses Pembelajaran Ansambel Gamelan Jawa

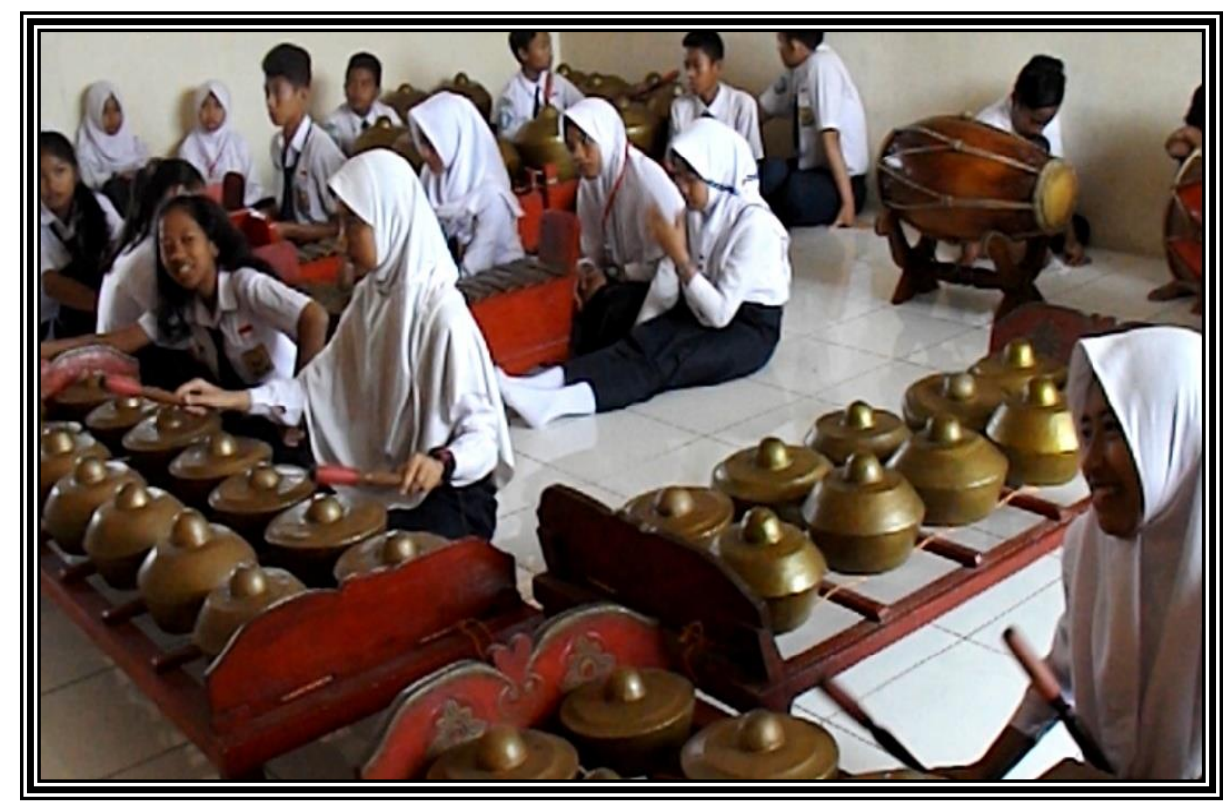

Gambar 5.23 Pergantian Kelompok Saat Latihan

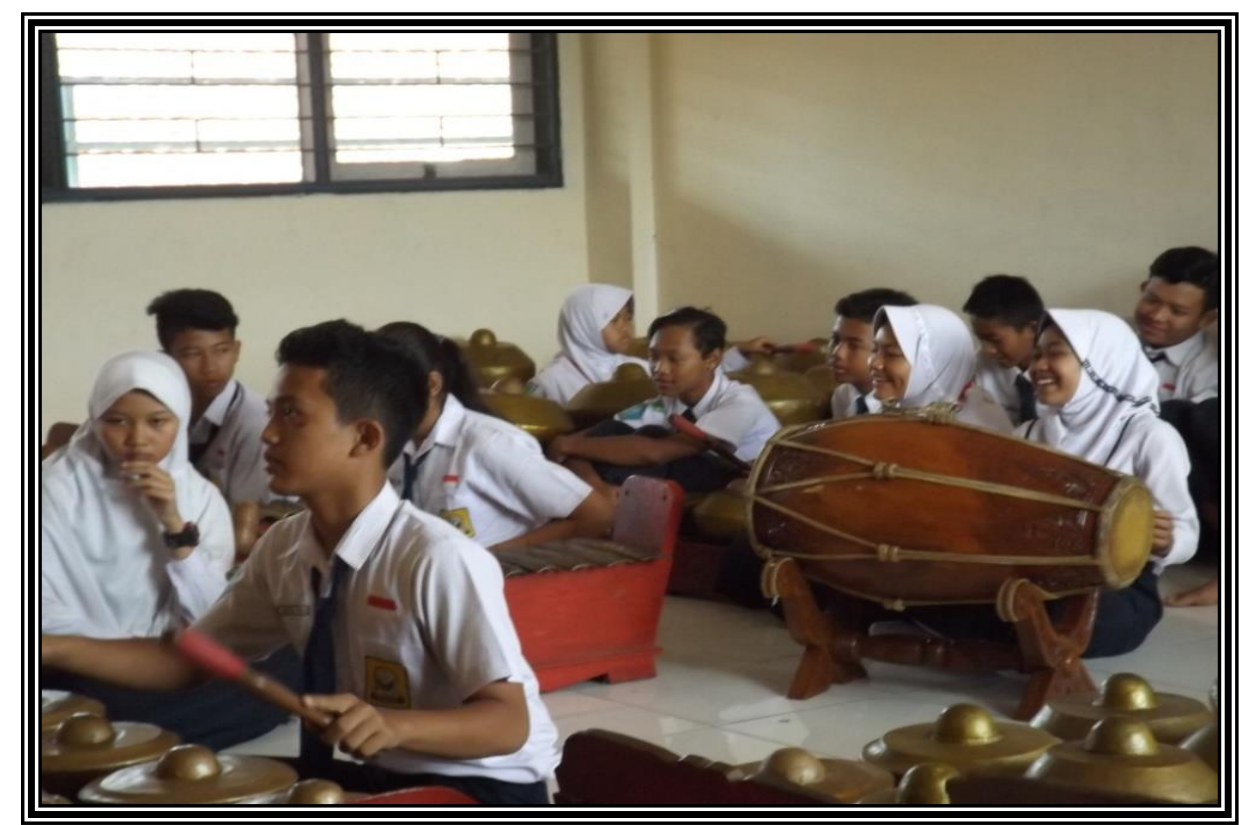

Gambar 5.24 Siswa Berlatih dengan Melihat Notasi di Papan Tulis Depan Kelas 


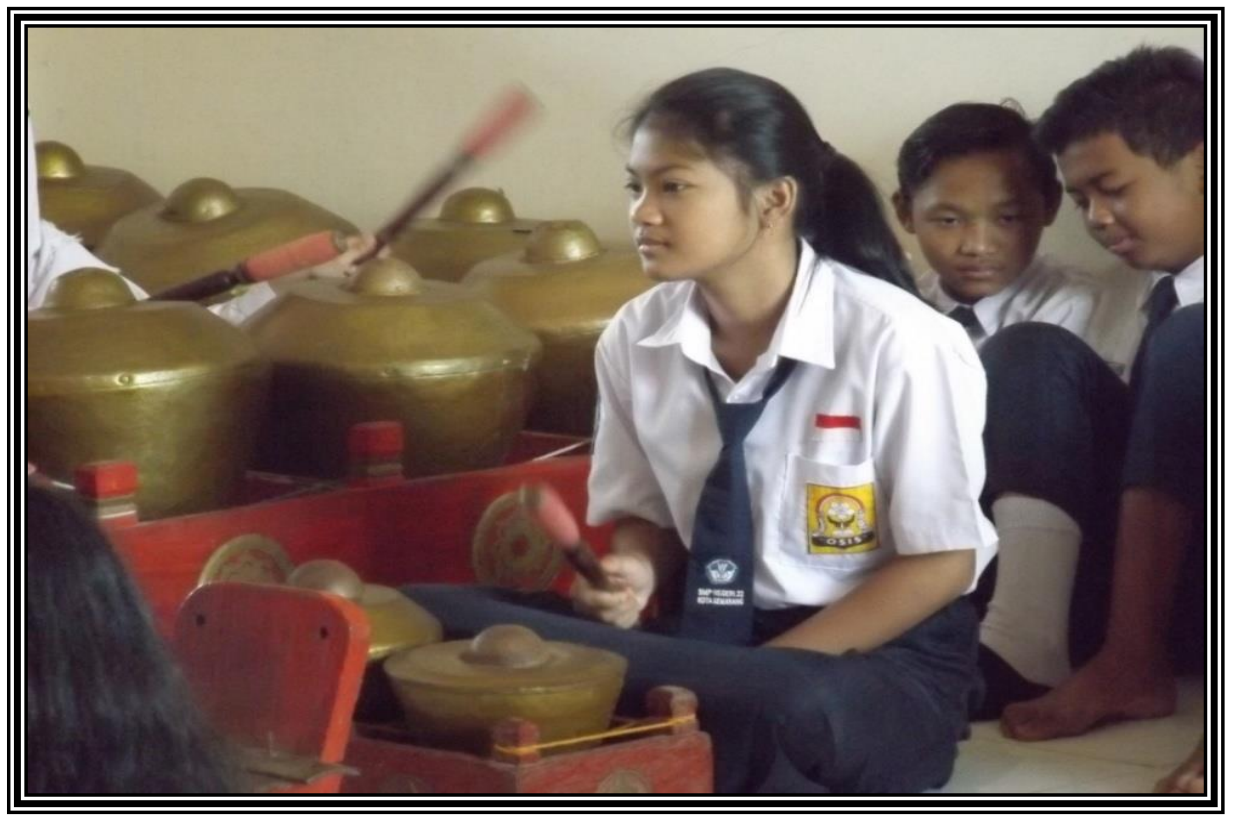

Gambar 5.25 Siswa yang Sedang Berlatih Memainkan Kethuk

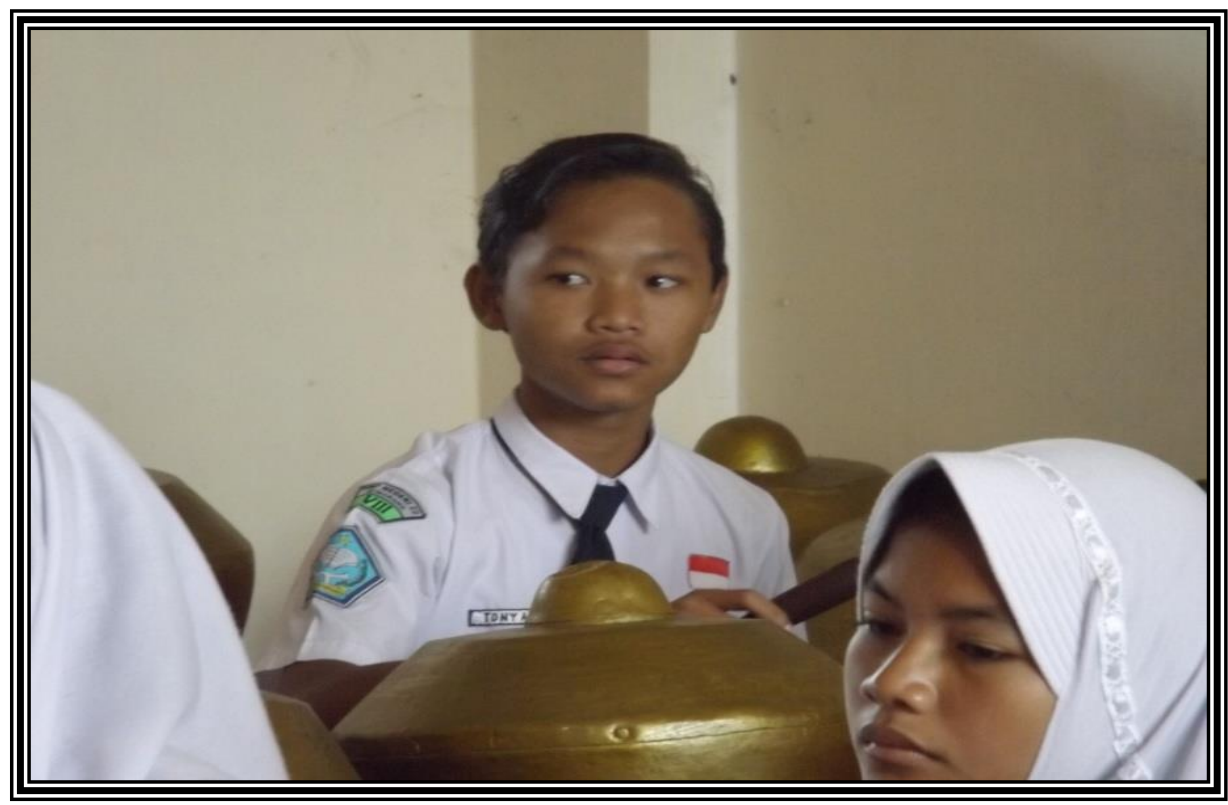

Gambar 5.26 Siswa Sedang Berlatih Memainkan Kenong 


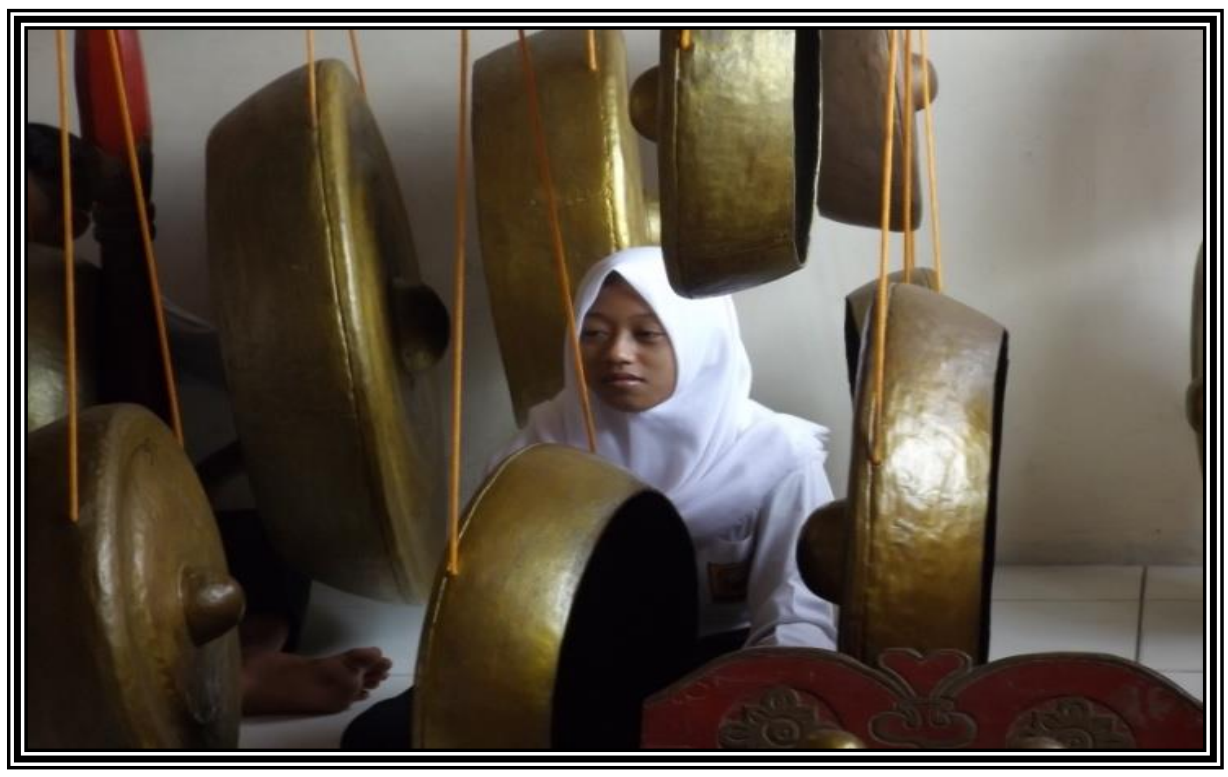

Gambar 5.27 Siswa Sedang Memainkan Gong

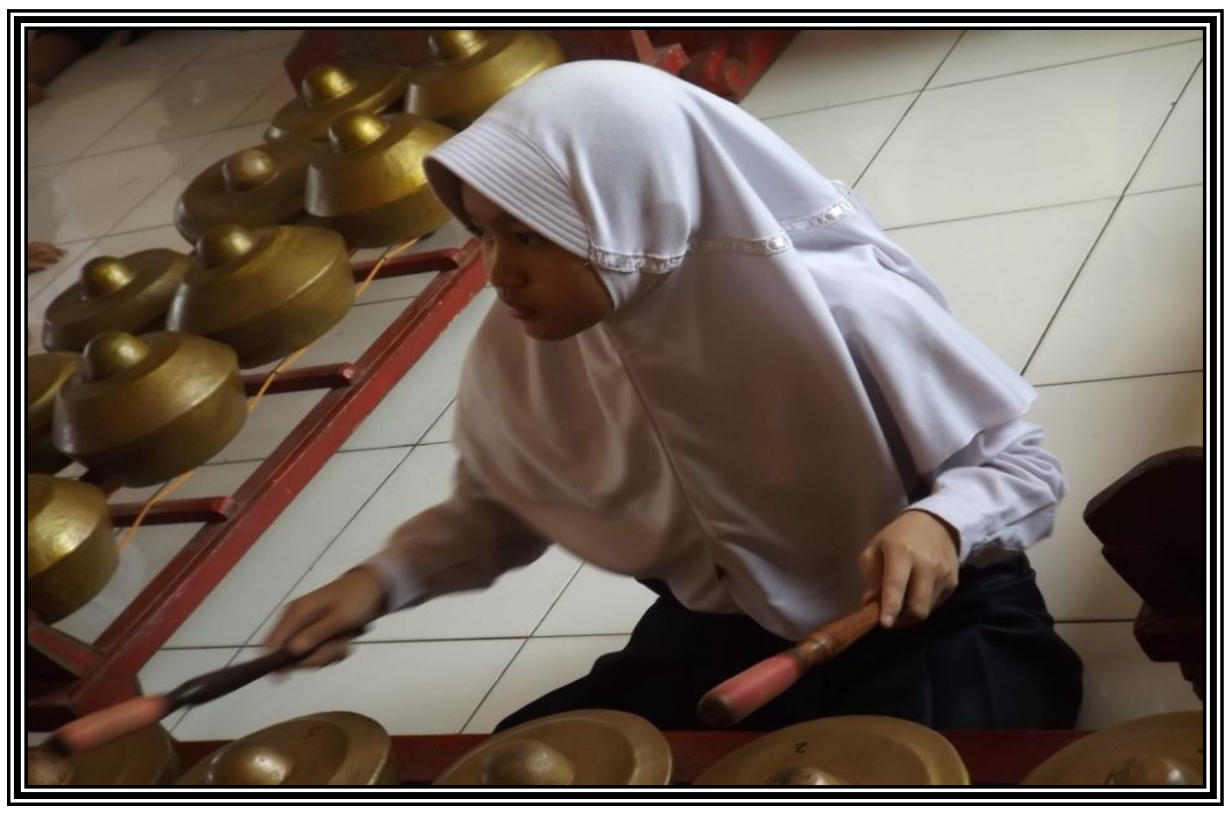

Gambar 5.28 Siswa Sedang Memainkan Bonang Penerus 


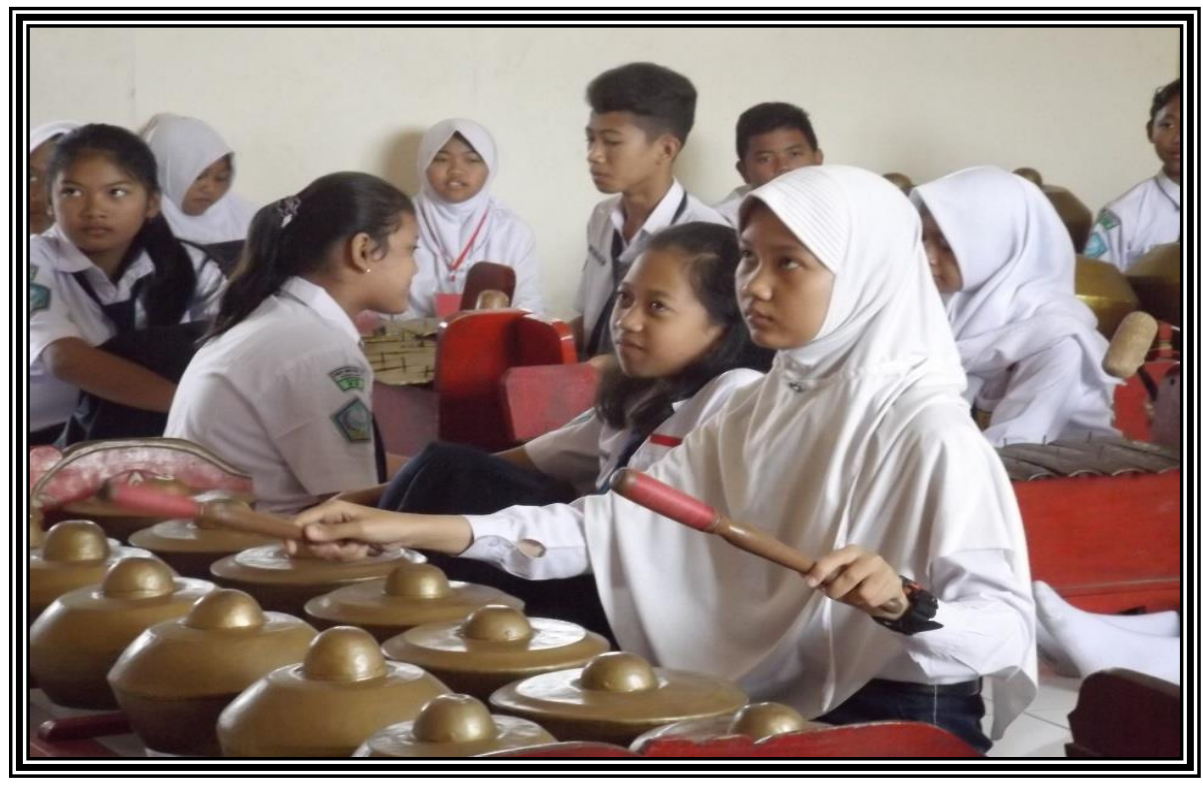

Gambar 5.29 Siswa Sedang Memainkan Bonang Barung

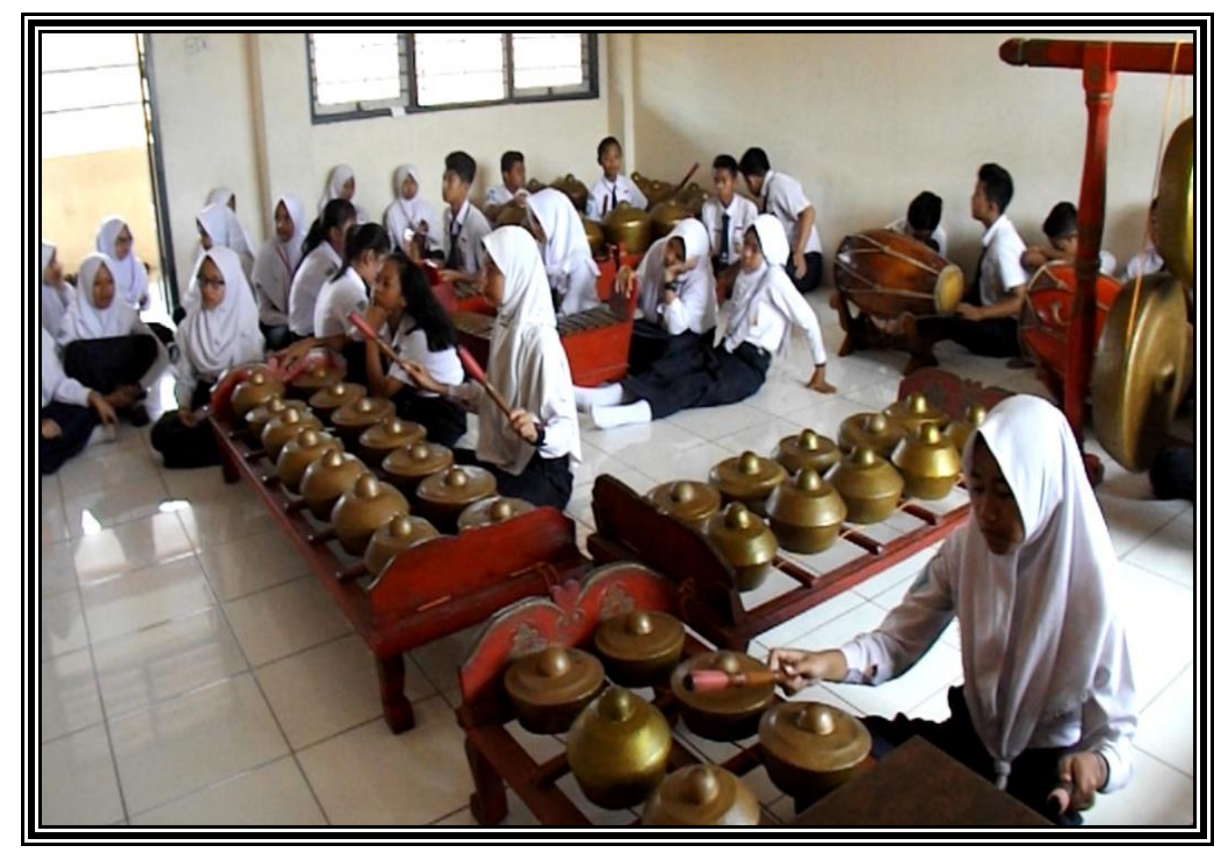

Gambar 5.30 Siswa Sedang Memainkan Seluruh Alat Musik Gamelan Jawa Secara Berkelompok 


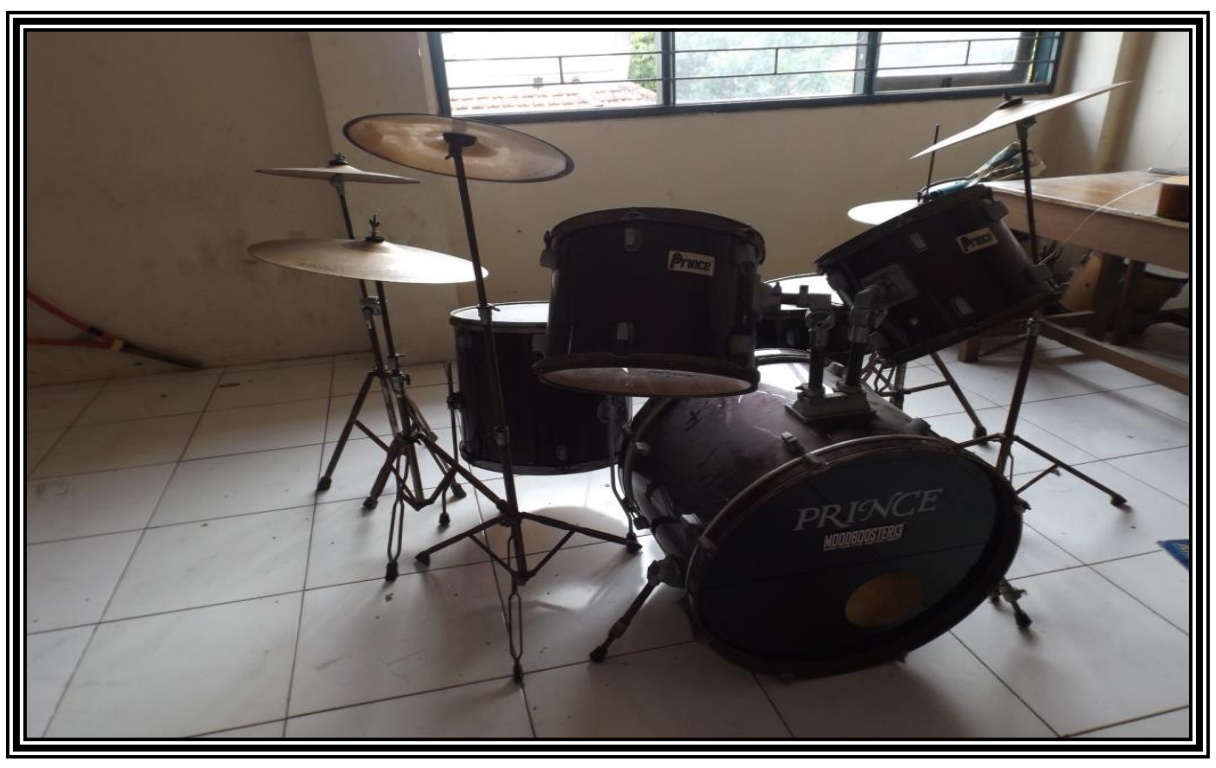

Gambar 5.31 Alat Musik Drum di Ruang Musik

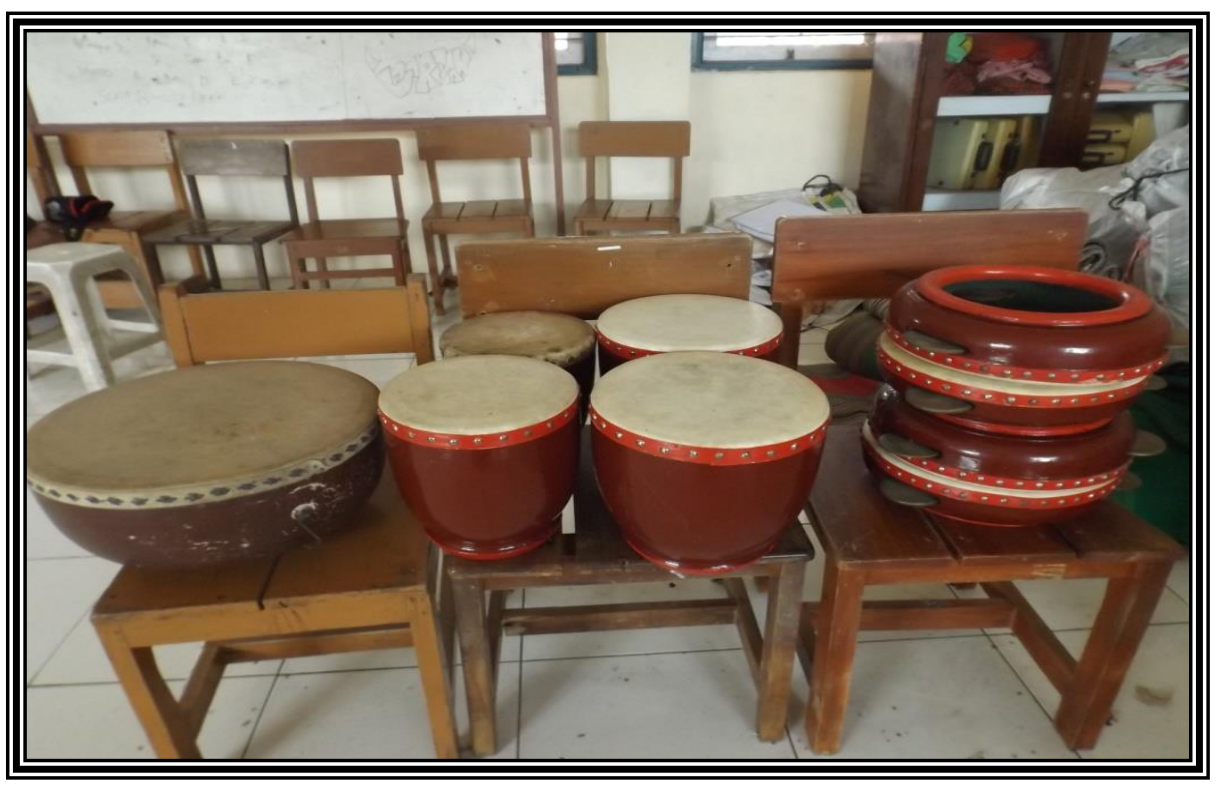

Gambar 5.32 Alat Musik Rebana di Ruang Musik 


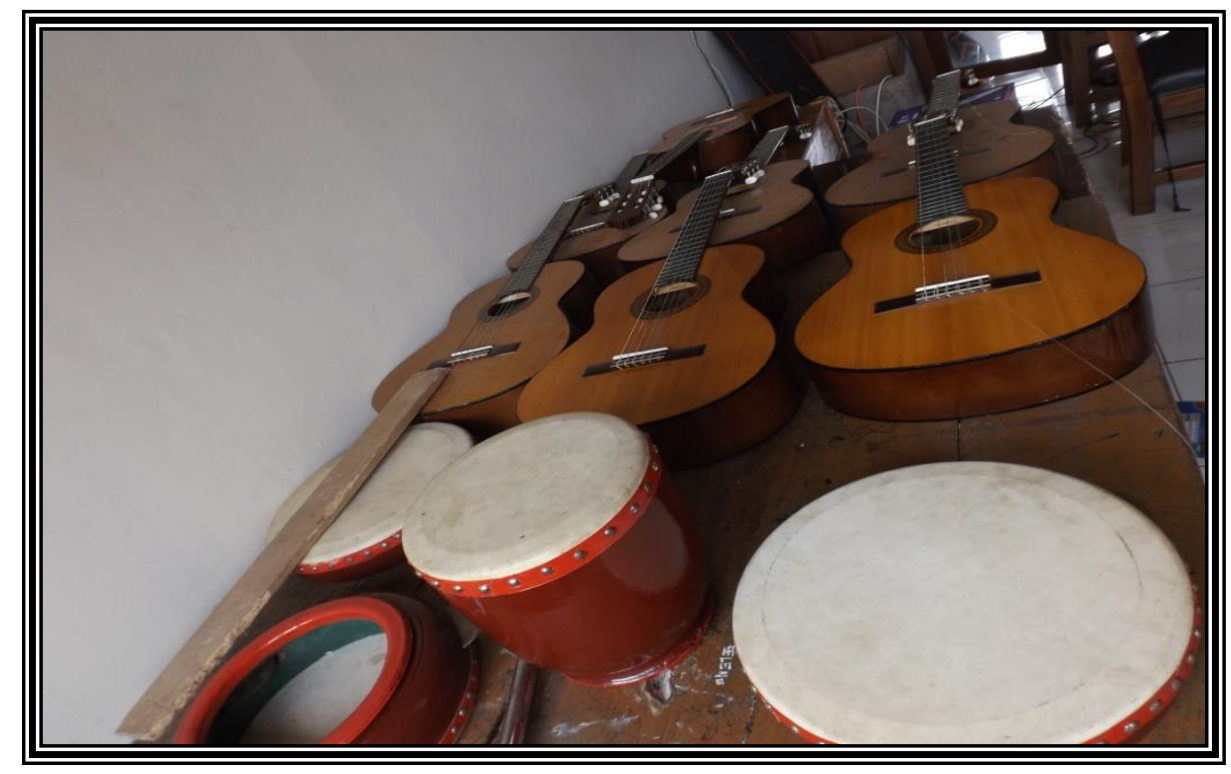

Gambar 5.33 Gitar Klasik di Ruang Musik

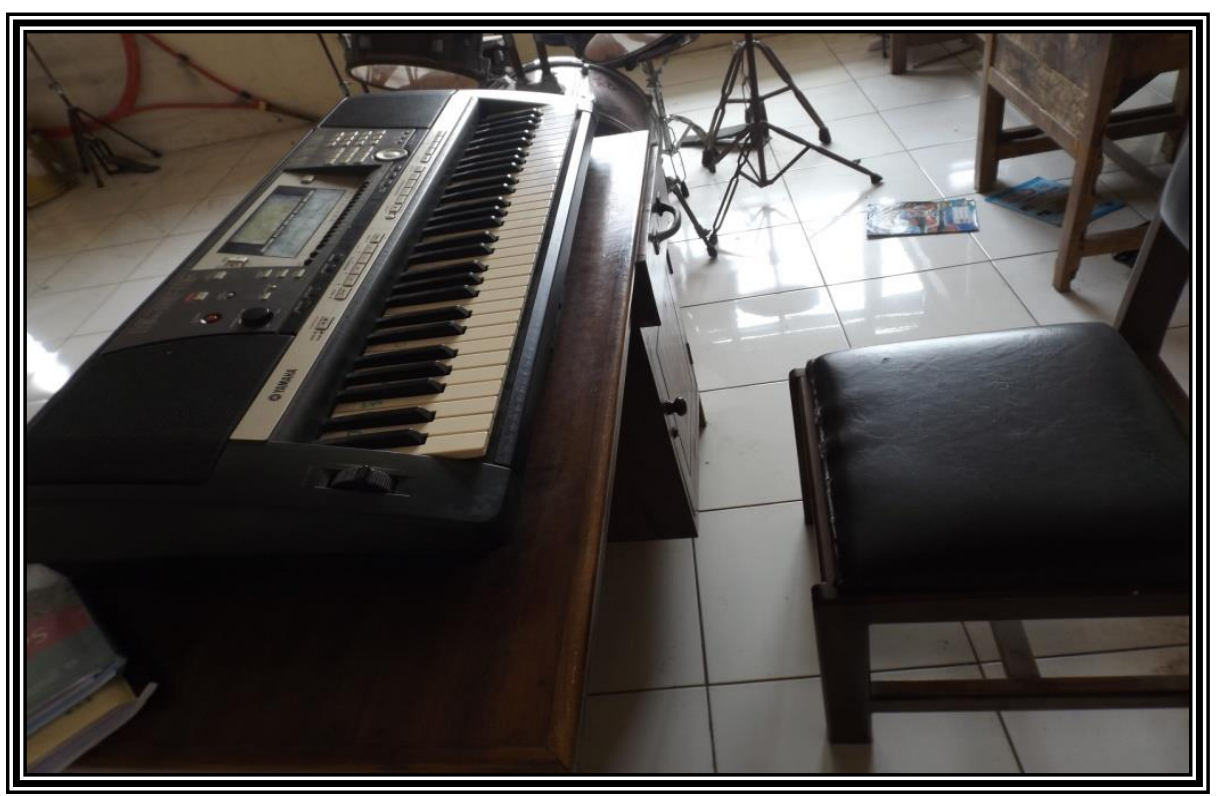

Gambar 5.34 Keyboard di Ruang Musik 


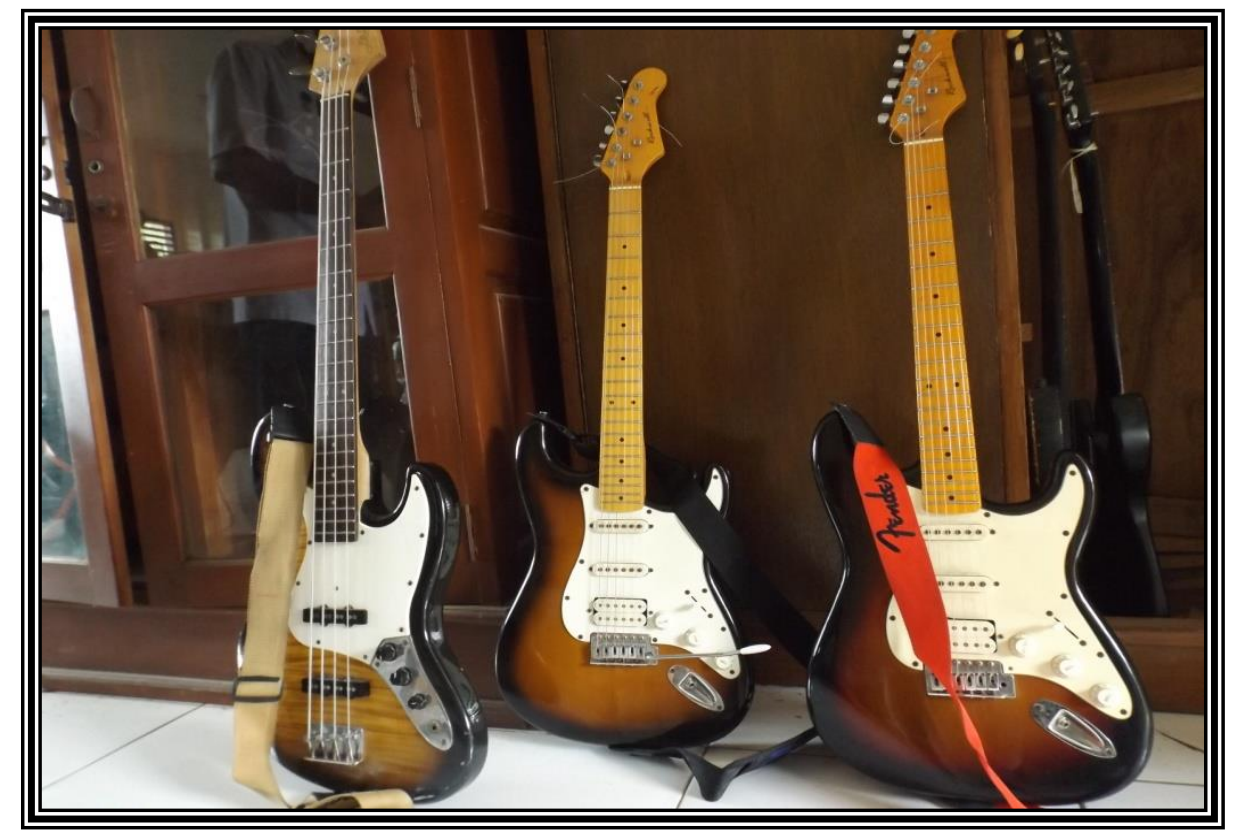

Gambar 5.35 Gitar di Ruang Musik

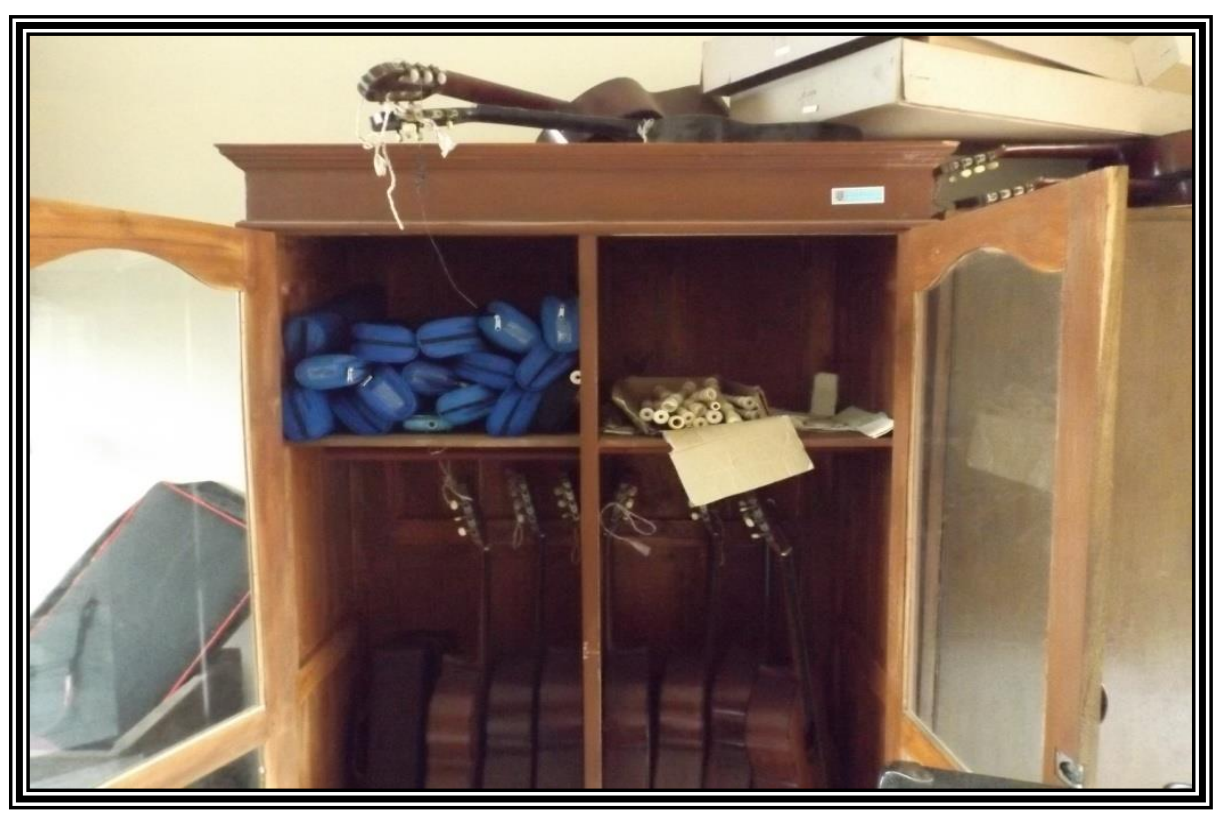

Gambar 5.36 Pianika dan Recorder di Ruang Musik 


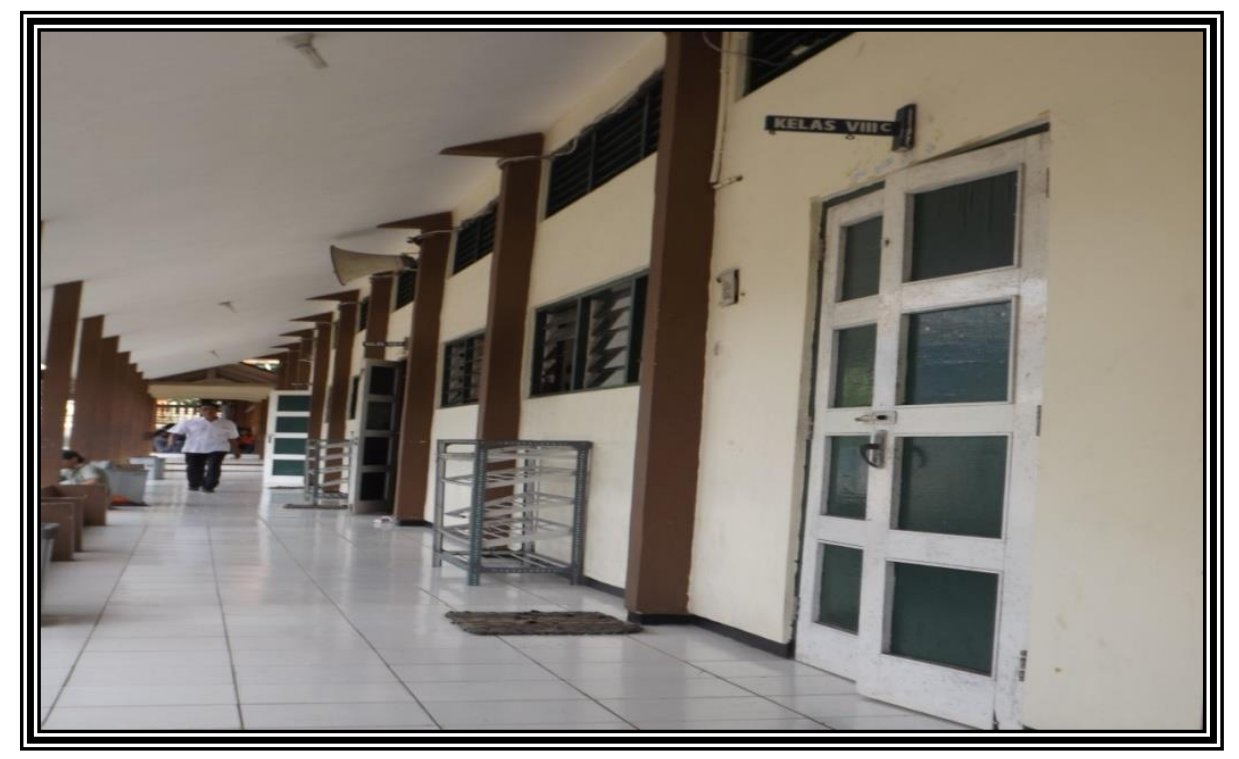

Gambar 5.37 Ruang Kelas 


\title{
Lampiran 7 Contoh Hasil Pengisisan Angket Siswa Kelas VIII C
}

\author{
ANGKET \\ Nama :M. Hanif.S \\ Kelas : villc \\ NO : 19 \\ ANGKET \\ Petunjuk pengisian : \\ 1. Melalui angket ini, Anda diminta memberikan pendapat anda terhadap \\ pembelajaran seni musik \\ 2. Pilihlah salah satu kemungkinan jawaban yang telah disediakan, yang \\ menurut pendapat Anda paling tepat. \\ 3. Pilihan jawaban : \\ SL: selalu \\ SR: sering \\ KK: kadang-kadang \\ TP : tidak pernah \\ 4. Anda cukup memberi tanda centang pada kolom yang sesuai dengan \\ pandangan dan keadaan anda \\ 5. Dalam hal ini tidak ada jawaban benar atau salah
}

\begin{tabular}{|c|l|c|c|c|c|}
\hline No. & \multicolumn{1}{|c|}{ Pernyataan } & $S L$ & $S R$ & KK & TP \\
\hline 1. & Suasana pada saat pembelajaran terasa nyaman & & $V$ & & \\
\hline 2. & $\begin{array}{l}\text { Materi pembelajaran seni musik mudah } \\
\text { dipahami }\end{array}$ & $\checkmark$ & & \\
\hline 3. & $\begin{array}{l}\text { Rasa ingin tahu saya tergerak oleh pertanyaan } \\
\text { yang dikemukakan dan masalah yang diberikan }\end{array}$ & $V$ & & \\
\hline
\end{tabular}




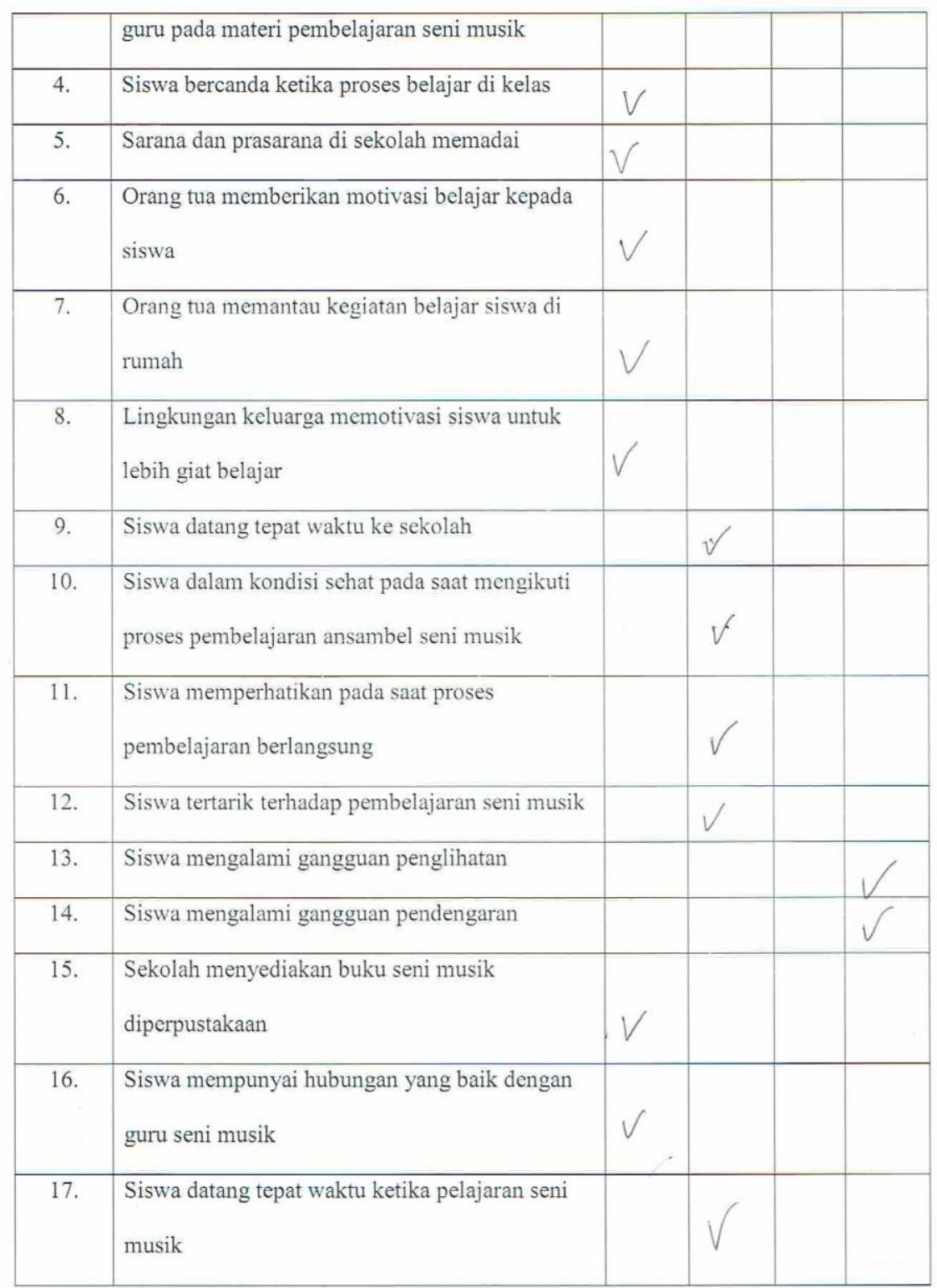




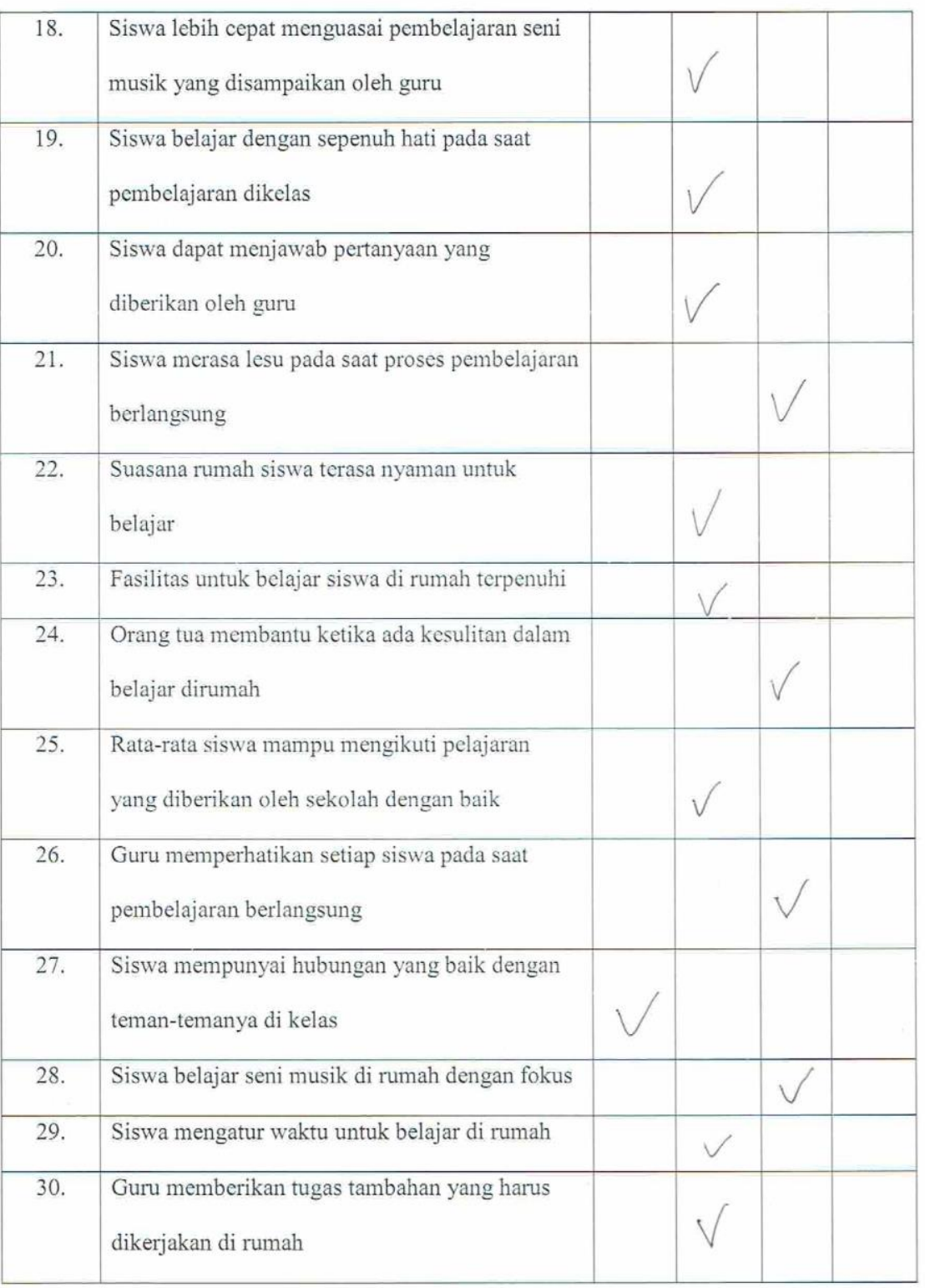




\begin{tabular}{|c|l|l|l|l|l|}
\hline 31. & $\begin{array}{l}\text { Siswa mengikuti kegiatan sosial yang diadakan } \\
\text { oleh lingkungan masyarakatnya }\end{array}$ & V & & & \\
\hline 32. & $\begin{array}{l}\text { Televisi memberikan informasi yang dibutuhkan } \\
\text { siswa dalam pembelajaran }\end{array}$ & V & & & \\
\hline 33. & $\begin{array}{l}\text { Lingkungan masyarakat membantu dan } \\
\text { mendorong semangat belajar siswa }\end{array}$ & V & & & \\
\hline
\end{tabular}


Lampiran 8 Surat Bukti Telah Melakukan Penelitian

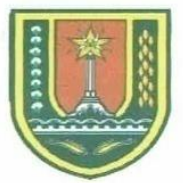

PEMERINTAH KOTA SEMARANG

DINAS PENDIDIKAN

SMP NEGERI 22 SEMARANG

Jalan Raya Gunungpati Semarang Telp.(024) 6932266 KP. 50225

\section{SURAT KETERANGAN}

Nomor : $070 / 425 / 2017$

Berdasarkan Surat dari Kepala Dinas Pendidikan Kota Semarang Nomor : 070 / 3337 tanggal, 13 April 2017 tentang Permohonan Ijin Penelitian dengan ini Kepala SMP Negeri 22 Semarang menerangkan bahwa,

Nama Yulfiani

NIM : 2501411069

Perguruan Tinggi : Universitas Negeri Semarang

Fakultas : Bahasa Dan Seni

Program Studi : Pendidikan Seni Musik

Telah mengadakan Penelitian di SMP Negeri 22 Semarang pada tanggal, 3 s.d 31 Mei 2017, dengan judul “ Pembelajaran Musik Ansabel di kelas VIIIC SMP Negeri 22 Semarang “.

Demikian Surat Keterangan ini untuk dapat dipergunakan seperlunya.

Semarang, 29 September 2017

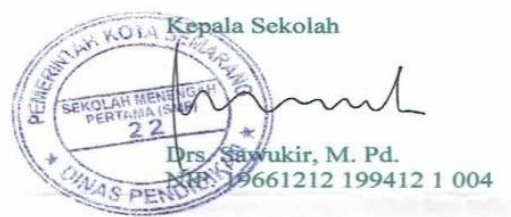




\title{
Lampiran 9 Surat Tugas Panitia Ujian Sarjana
}

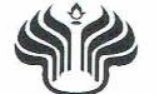 \\ KEMENTERIAN RISET, TEKNOLOGI, DAN PENDIDIKAN TINGGI \\ UNIVERSITAS NEGERI SEMARANG ( UNNES ) \\ FAKULTAS BAHASA DAN SENI \\ UNNES \\ Gedung B, KampusSekaran. Gunungpati, Semarang 50229

\begin{tabular}{|l|c|c|c|}
\hline No.Dok. FM-06-AKD-20 & No. Revisi : 02 & TolBerlaku: 11 Sept. 2013 & Hataman: Idaril \\
\hline Nomor : 9149 UN37.1.2/DK 2017 &
\end{tabular} \\ Nomor : 9149 UN 37.1 .2 DK 2017
Hal. \\ Dengan ini kami tetapkan bahwa ujian Sarjana Fakultas Bahasa dan Seni UNNES untuk Jurusan Sendratasik \\ adalah sebagai berikut: \\ I.

SusunanPanitiaUjian:
\begin{tabular}{|l|l|l|l|}
\hline a. & Ketua & $:$ & Drs. Syahrul Syah Sinaga, M.Hum. \\
\hline b. & Sekretaris & $:$ & Dra. Malarsih, M.Sn. \\
\hline c. & Pembimbing(Penguji 3) & $:$ & Drs. Suharto, S.Pd., M. Hum. \\
\hline d. & Penguji & $:$ & 1 . Dr. Udi Utomo, M.Si. \\
\hline & & & 2. Abdul Rachman, S.Pd.,M.Pd. \\
\hline
\end{tabular} \\ II.

\begin{tabular}{|c|c|c|c|}
\hline Nama & NIM & Program Sudi & \\
\hline Yulfiani & 2501411069 & $\begin{array}{l}\text { Pendidikan } \\
\text { Seni Musik }\end{array}$ & $\begin{array}{l}\text { PEMBELAJARAN ANSAMBEL SEN } \\
\text { MUSIK DI KELAS VIIG SMPN } 22 \\
\text { SFMARANG }\end{array}$ \\
\hline
\end{tabular} \\ III.

$$
\begin{aligned}
& \text { Hari/ Tanggal : Rabu/11 Oktober } 2017 \\
& \text { Jam } \quad: 13.00 \text { WIB } \\
& \text { Tempat :B2. R.10 } \\
& \begin{array}{ll}
\text { Pakaian } & \text { : Hem lengan panjang berdas } \\
\text { - Calon yang diuji } & \text { : Hitam Putih berjaket almam }
\end{array}
\end{aligned}
$$ \\ Demikian surat tugas ini kami buat untuk dilaksanakan sebaik-baiknya.
}

6 Oktober 2017

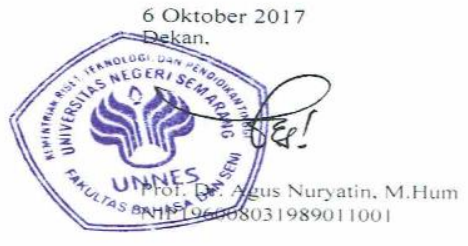

Tembusan:
1. Ketua Jurusan Sendratasik:
2. Calon yang diuji. 


\section{Lampiran 10 Surat Keputusan Bimbingan Skripsi}

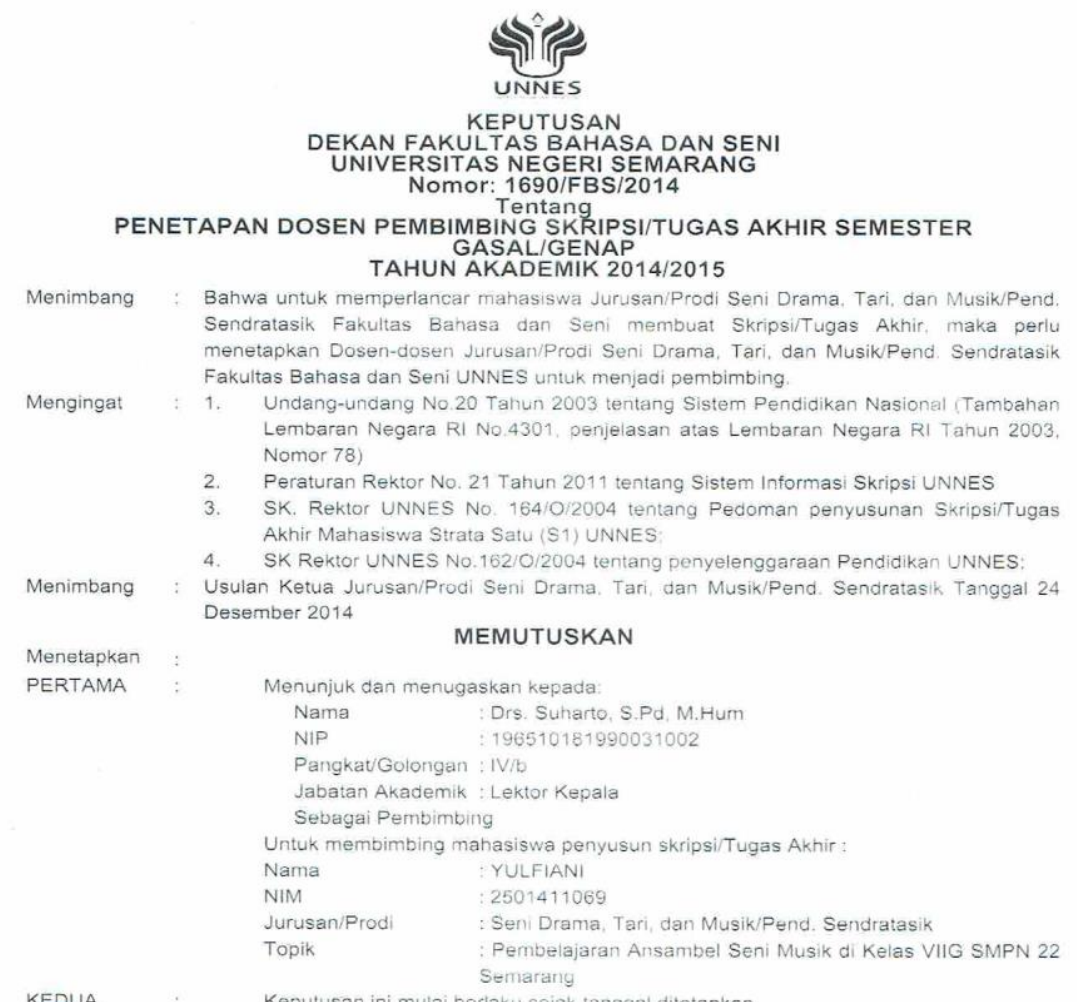

KEDUA

Keputusan ini mulai berlaku sejak tanggal ditetapkan.

1. Pembantu Dekan Bidang Akademik

2. Ketua Jurusan

OITETAPKAN DI : SEMARANG

3. Petinggal

PADA TANGGAL : 24 Desember 2014

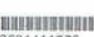

2501411069

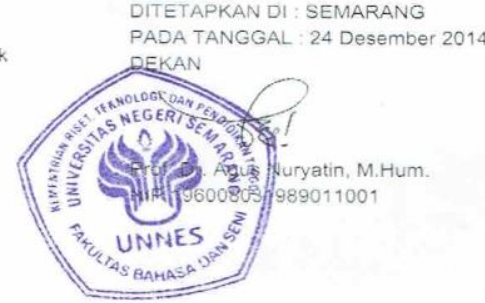

